\title{
التأثير المحتمل لجائحة كوفيا 19 على جودة عملية التدقيق
}

\author{
أ. محمد عاطف ماضية \\ د. د الربد الرحمن محمد رشوان

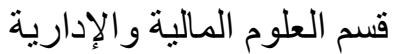 \\ قسم المحاسبة_كلية التجارة-جامعة بنها

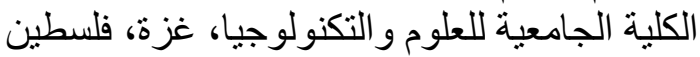 \\ abdrashwan@yahoo.com
}

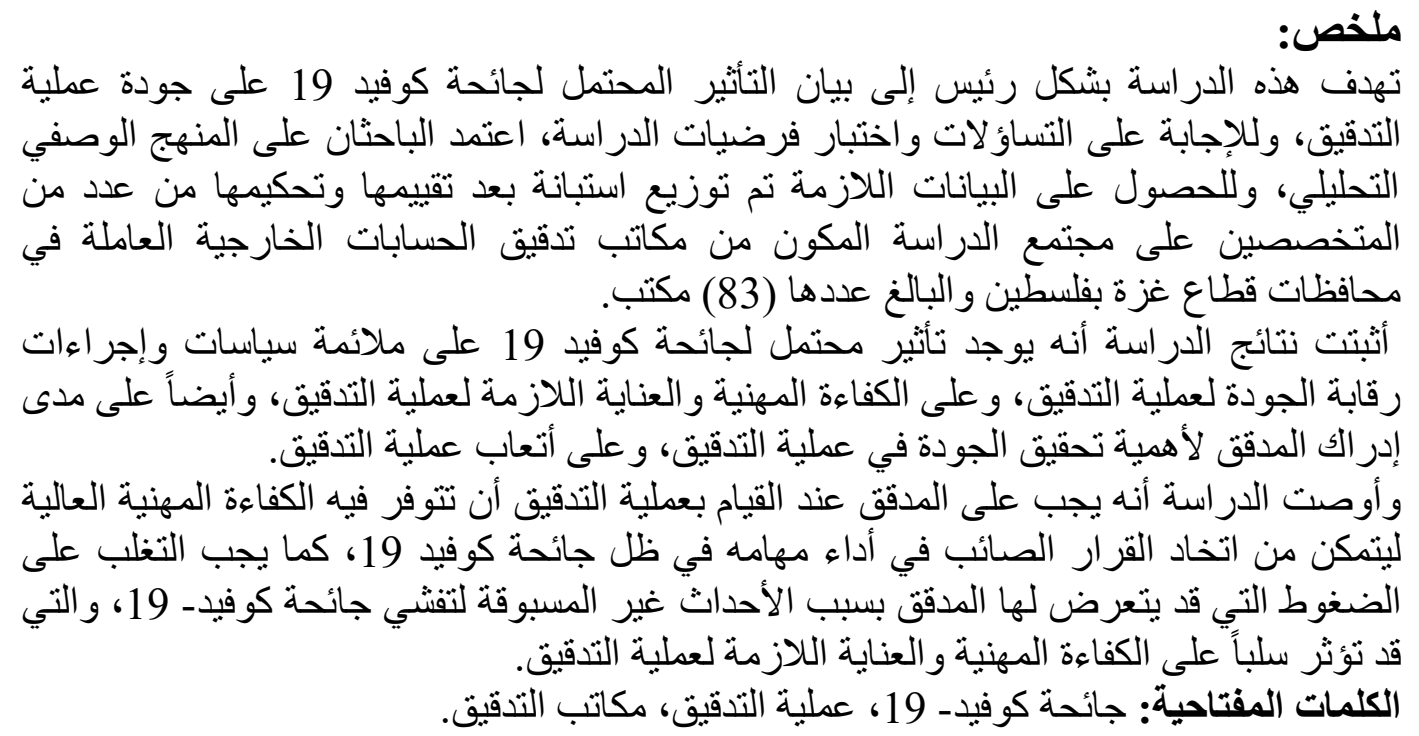

Abstract:

This study mainly aims to indicate the potential impact of the Coved 19 pandemic on the quality of the audit process, and to answer questions and test the study hypotheses, the researchers relied on the descriptive analytical method, and to obtain the necessary data was distributed after evaluation and arbitration by a number of specialists to the study community consisting of external audit offices operating in the governorates of the Gaza Strip in Palestine and the (83) offices.

The results of the study demonstrated that there is a potential impact of the Coved 19 pandemic on the appropriateness of quality control policies and procedures for the audit process, on the professionalism and care required for the audit process, as well as on the auditor's awareness of the importance of quality in the audit process, and on audit fees.

The study recommended that the auditor in carrying out the audit process must have high professionalism in order to be able to make the right decision in the performance of his duties under the Coved 19 pandemic, and must overcome the pressures that the auditor may be exposed to due to the unprecedented events of the outbreak of the Coved-19 pandemic, which may negatively affect the professionalism and care necessary for the auditprocess.

Key words: Coved-19 pandemic,audit process, audit offices.

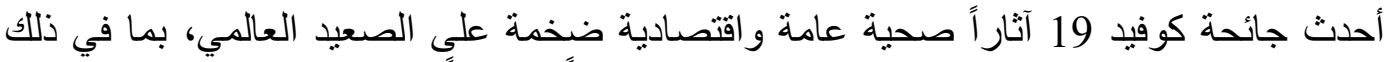

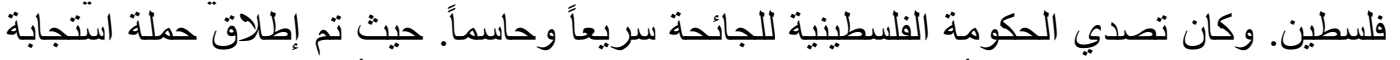

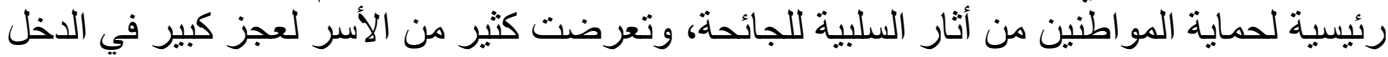

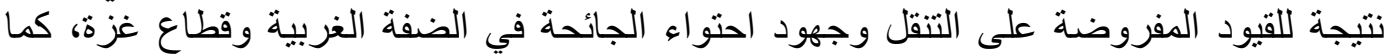

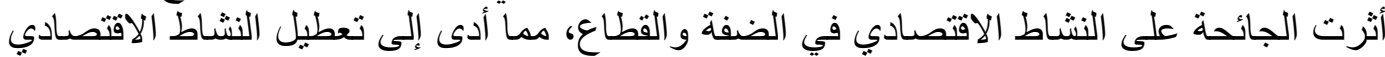

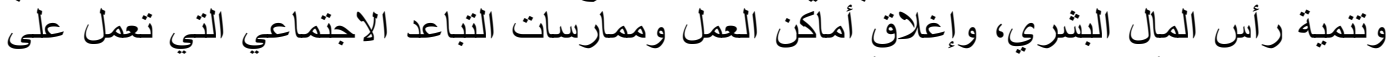

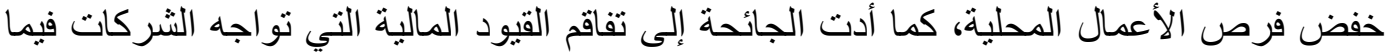
يتعلق بالإير ادات و السيولة. 
كما إن معظم الثركات قد تعرضت إلى أزمة كبيرة بسبب انتشار جائحة كوفيد-19 دون أن تكون

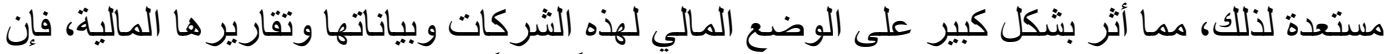

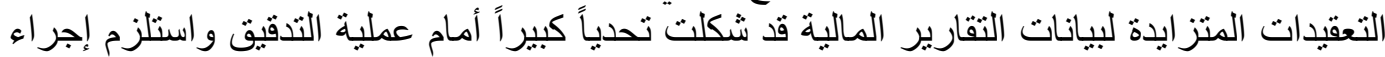

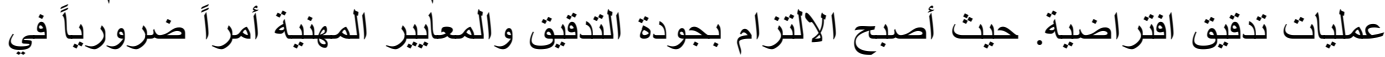

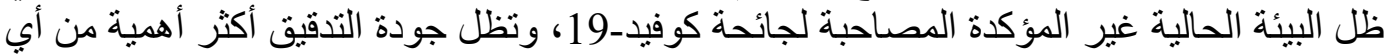

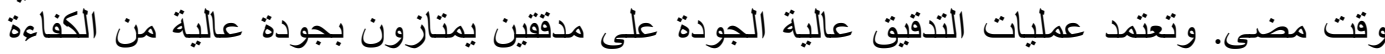

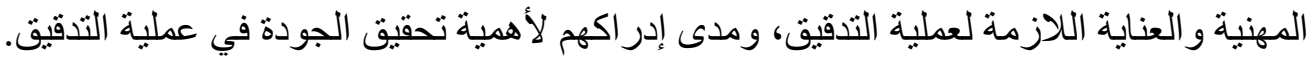

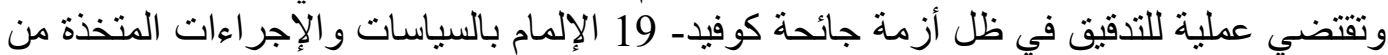

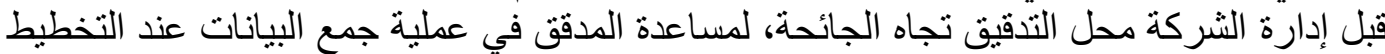

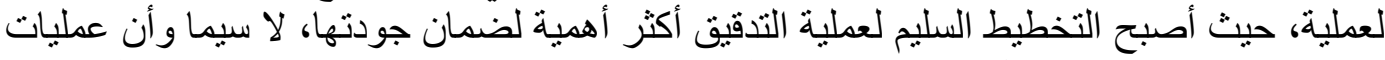

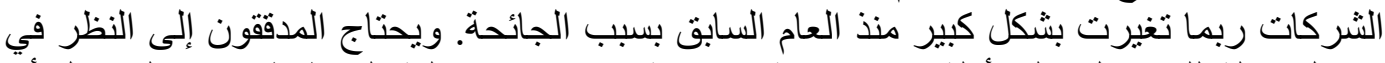

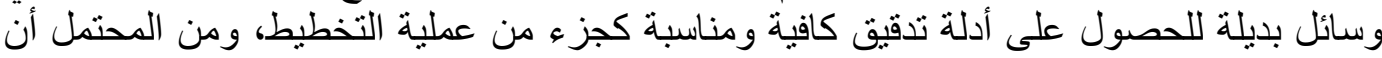

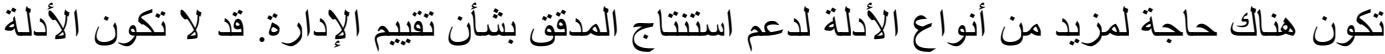

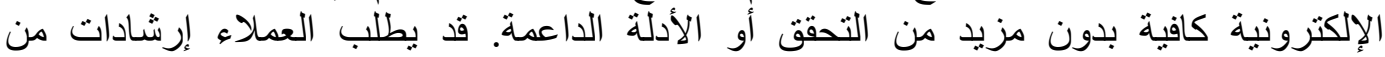

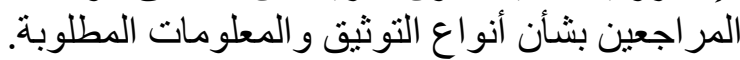

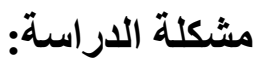

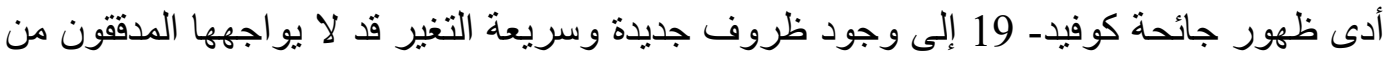

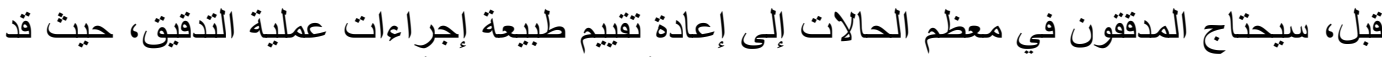

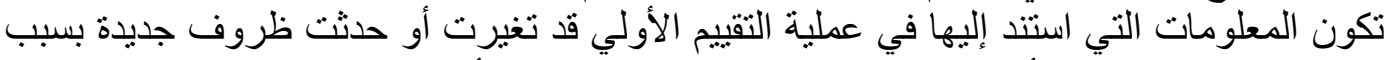

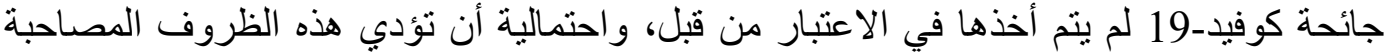

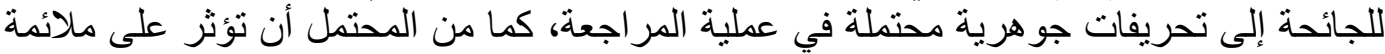

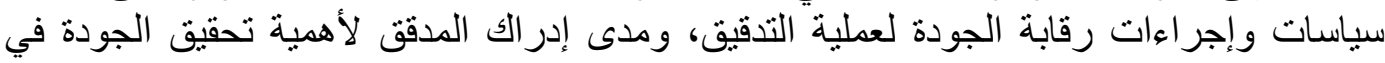

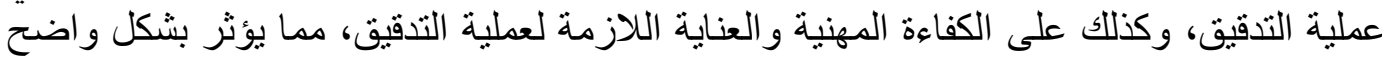
على أتعاب عملية التدقيق، ويمكن من خلال ما سبق صياغة مشكلة الدر اسة في التساؤلات البحة البحثية

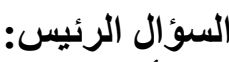

ما التأثثر المحتمل لجائحة كوفيد 19 على جودة عملية التدقيق؟ ويتفرع من السؤال الرئيس التساؤلات الفرعية التائلية التية:

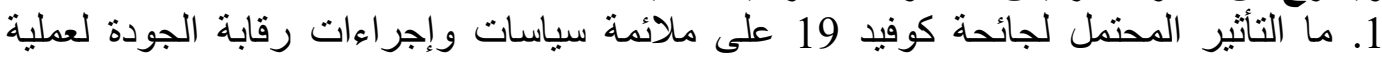

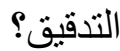

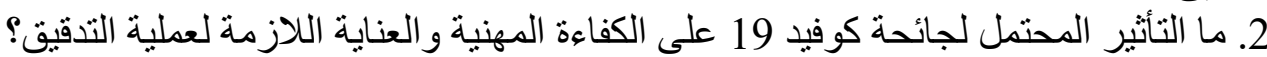
3. ما التأثثر المحتمل لجائحة كوفيد 19 على مدى إدراك المدقق لأهمية تحقيق الجودة في عملية

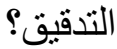

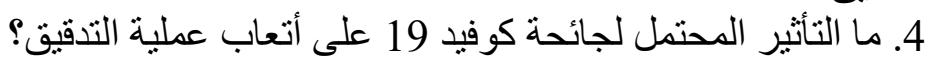
5. هل يوجد فروق بين منوسطات استجابات المبحوثين حول التأثير المحتمل لجائحة كوفيد 19

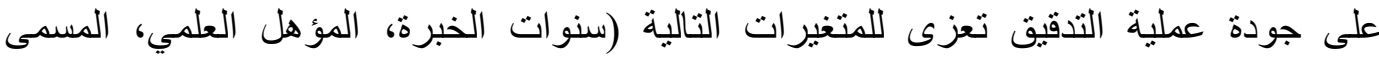
الوظيفي)؟

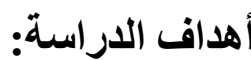
يتمثل الهدف الرئيس للار اسة في بيان التأثثر المحتمل لجائحة كوفيد 19 على جودة عملية التدقيق،

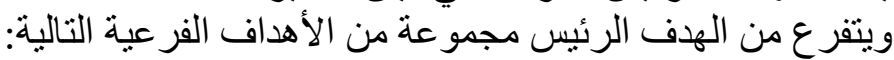

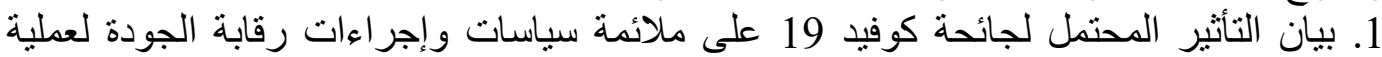

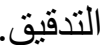
2. بيان التأثثر المحتمل لجائحة كوفيد 19 على الكفاءة المهنية والعناية اللازمة لعملية التدقيق. 3. بيان التأثثر المحتمل لجائحة كوفيد 19 على مدى إدراك الكيد المدقق لأهمية تحقيق الجودة في عملية 4. بيان التأثير المحتمل لجائحة كوفيد 19 على أتعاب عملية التدقيق. 


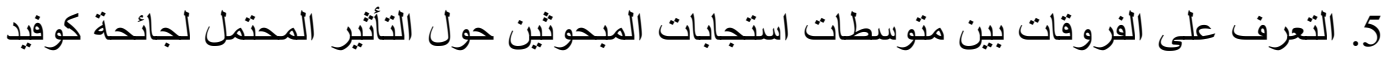

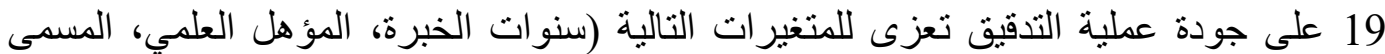

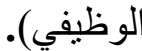

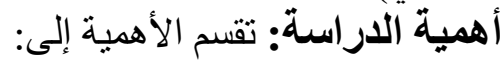

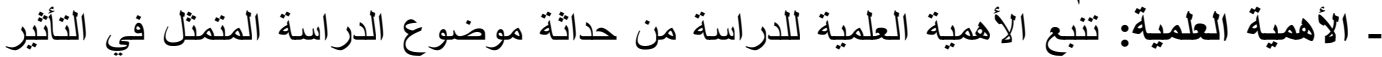

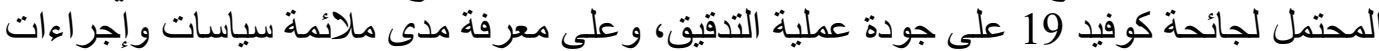

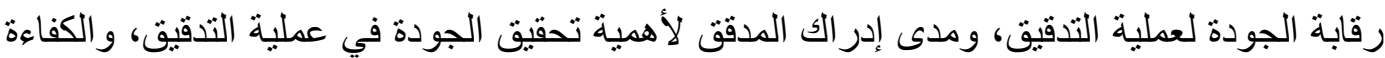
المهنية و العناية اللازمة لعملية التدقيق، و أتعاب عملية التهابة التدقيق.

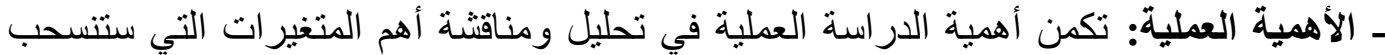

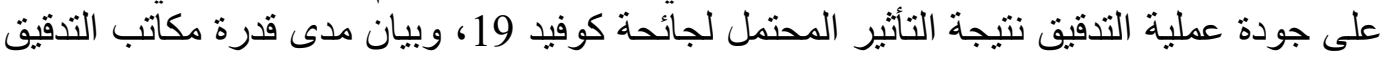

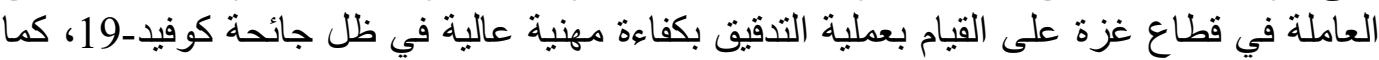

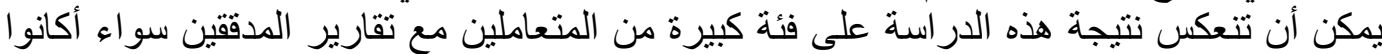

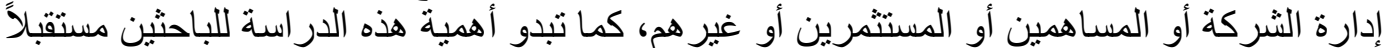
في هذا المجال.

فرضيات الدراسة: في ضو ضوضيات مشكلة وأهداف وأهة وأهية الدر اسة يمكن صياغة فرضيات الدر اسة كما يلي: القرضية الرئيسة: لا توجد علاقة ذات دلالة إحصائية بين التأثثر المحتمل لجائحة كوفيد 19 وجودة عملية التدقيق.

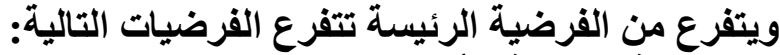

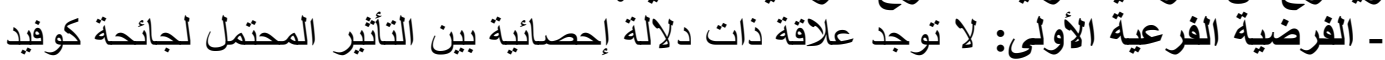
19 وملائمة سياسات و إجر اءعات رقابة الإبة الجودة لعملية التدقيق. ـ الفرضية الفرعية الثانية: لا توجد علاقة ذات دلالة إحصائية بين التأثير المحتمل لجائحة كوفيد 19 و الكفاءة المهنية والعناية اللازمة لعملية التية التدقيق. ـ الفرضية الفرعية الثالثة: لا توجد علاقة ذاتية ذات دلالة إحصائية بين التأثنير المحتمل لجائحة كوفيد 19 ومدى إدر اك المدقق لأهمية تحقيق الجودة فئة في عملية التدقيق. ـ الفرضية الفرعية الرابعة: لا نوجد علاقة ذات دلالة إحصائية بين التأثير المحتمل لجائحة كوفيد 19 و أتعاب عملية التدقيق.

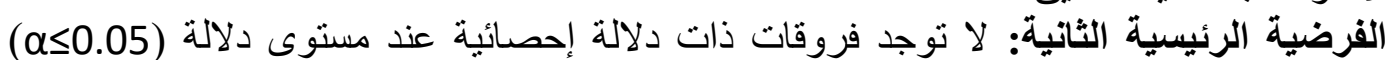

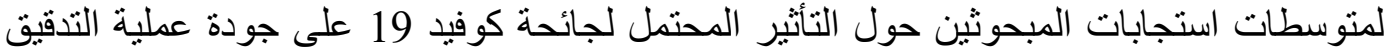
تعزى للمتغير ات التالية (سنو ات الخبرة، المؤهل العلئ العلمي، المسمى الوظيفي).

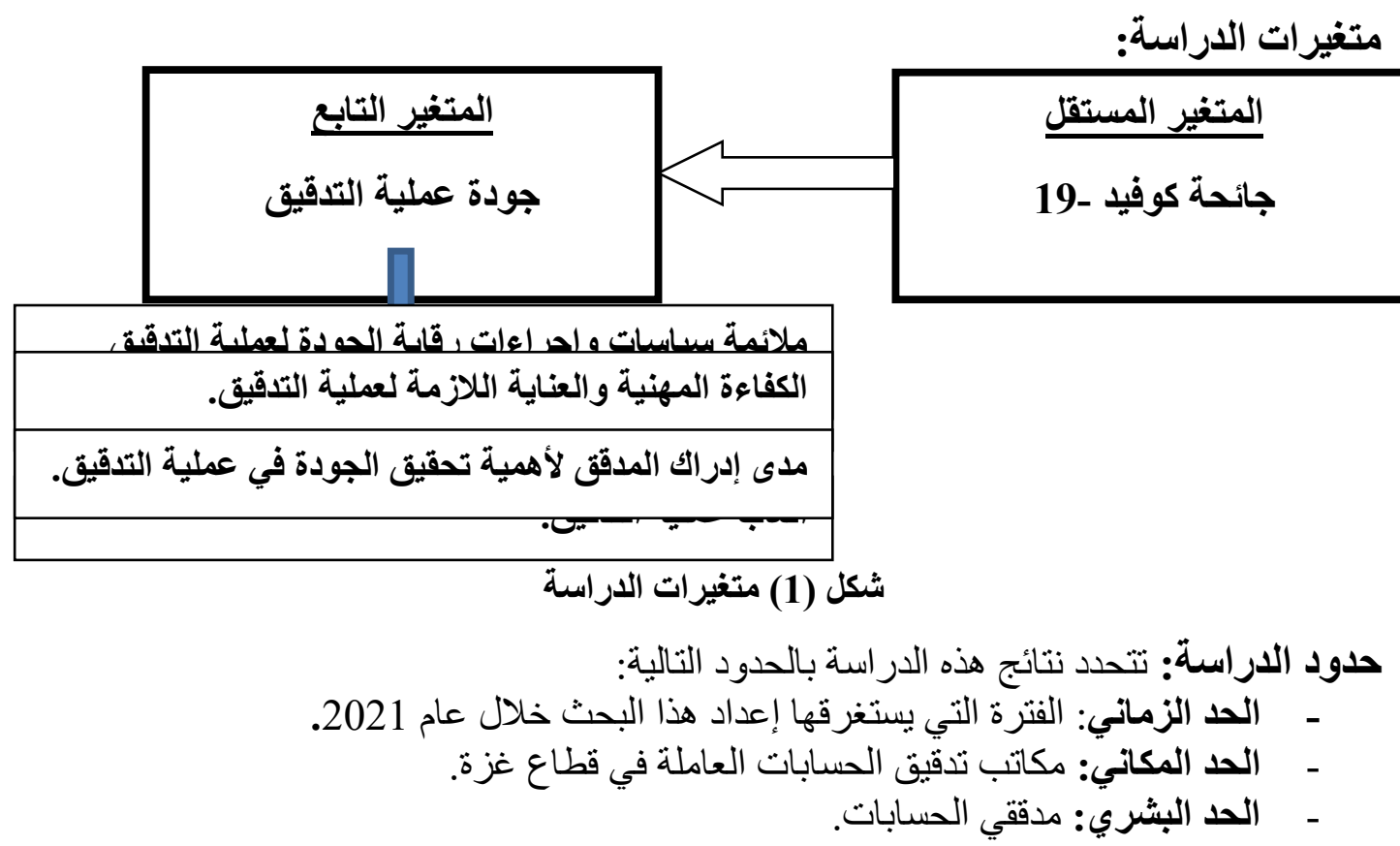


- الحد الموضوعي: دراسة التأثنير المحتمل لجائحة كوفيد 19 على جودة عملية التدقيق.

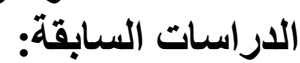

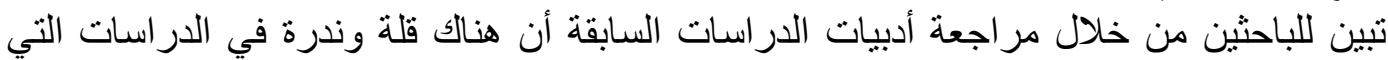
تناولت التنأثير المحنمل لجائحة كوفيد 19 على جودة عملية التدقيق، ويمكن سرد الدر اسات السابقة

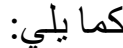

ناقتت دراسة (Albitar, et al, 2020) تأثثر التباعد الاجتماعي لتفتي جائحة كوفيد 19 على ألى

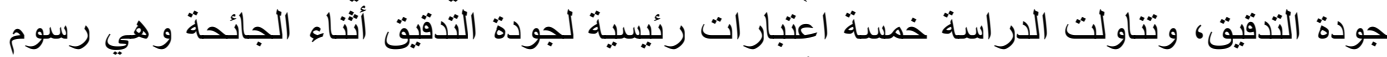

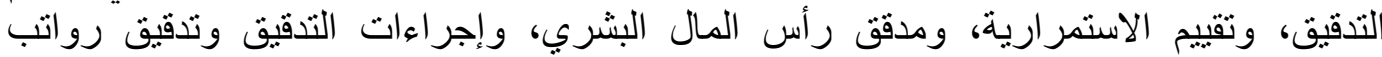

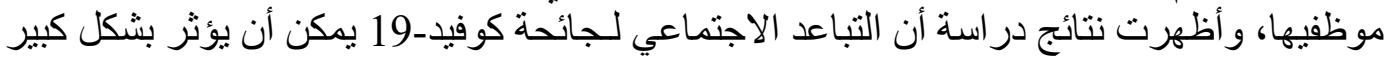

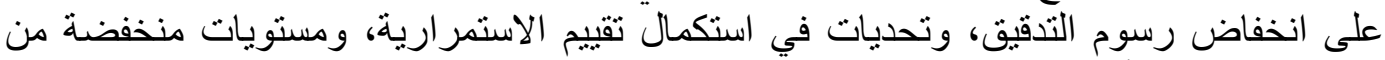

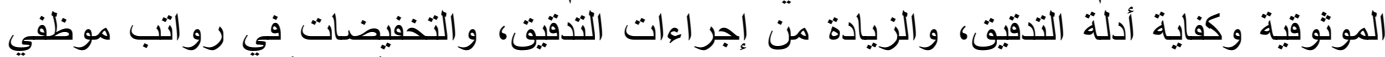

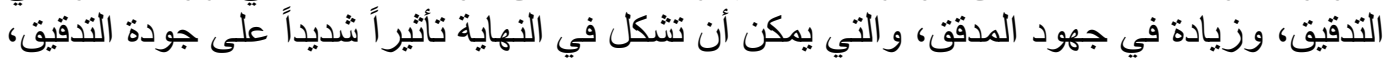

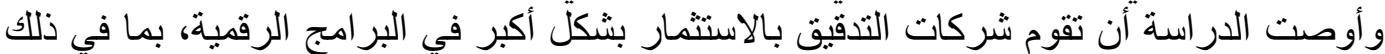

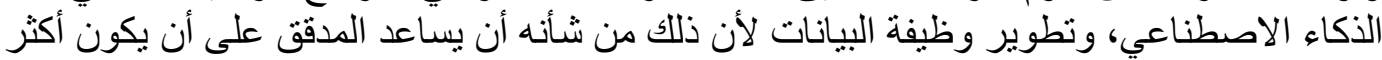

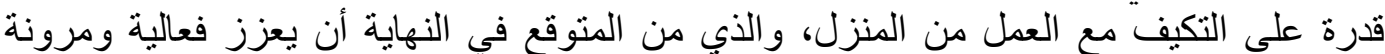
الاتصال بين المدققين وعملائهم نظر اً للتطبيقات العالمية لاستر اتيجية الإغلاق التي التي يُعتقد أنها تزيد

من ساعات العمل وجهود المدقوقين.

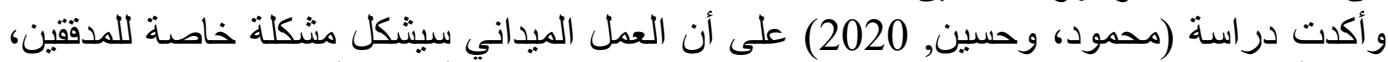

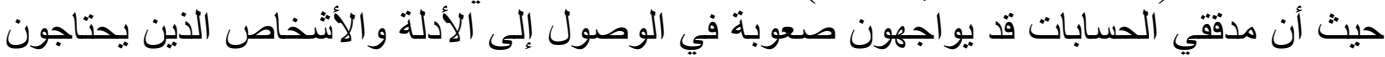

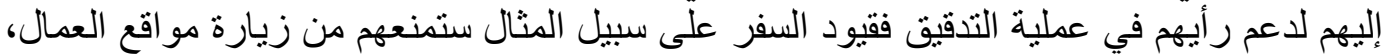

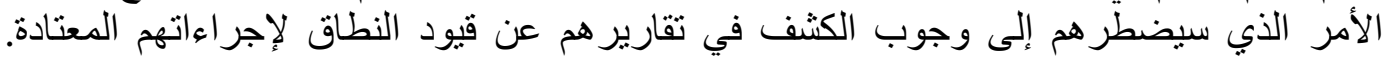

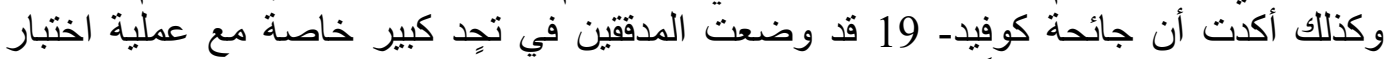

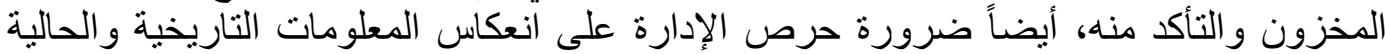

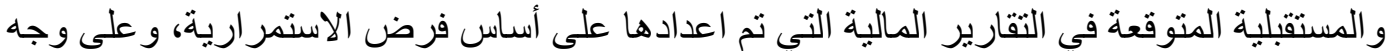

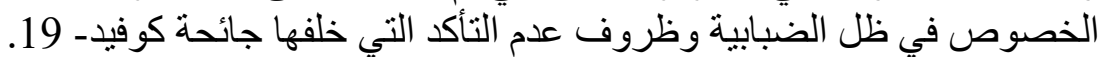

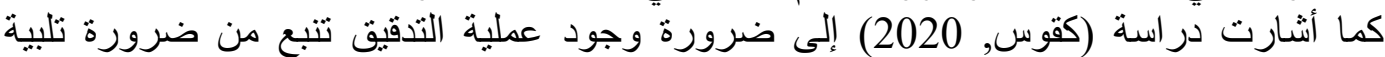

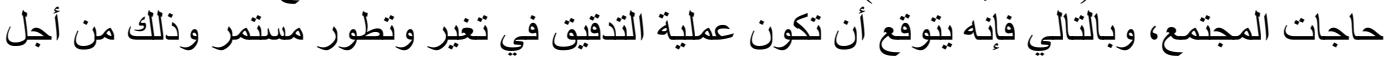

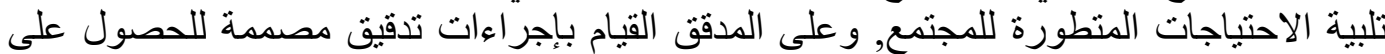

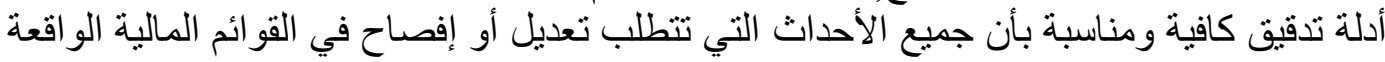

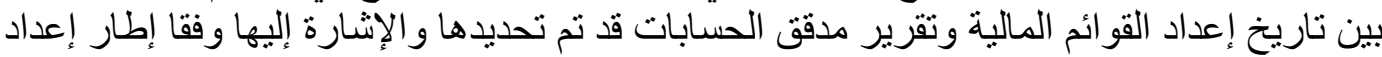

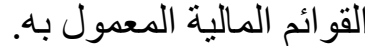

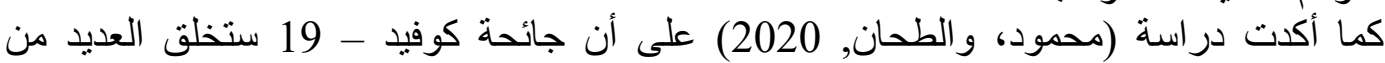

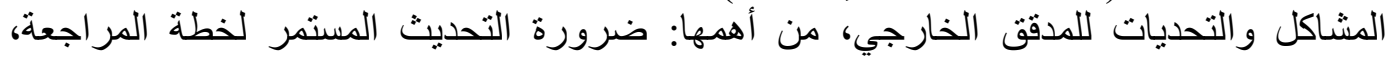

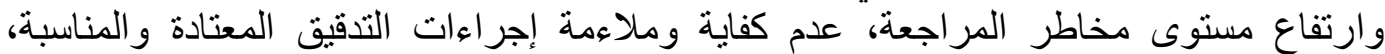

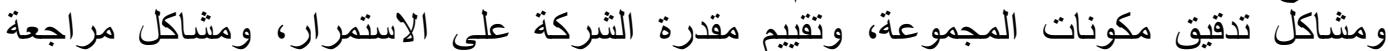

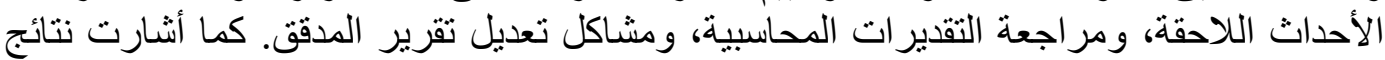

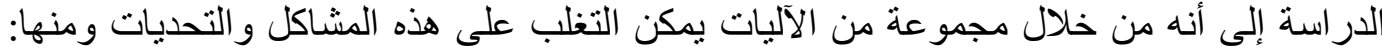

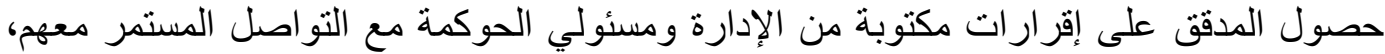

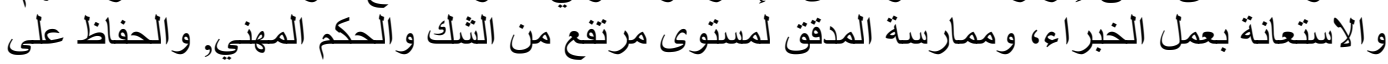

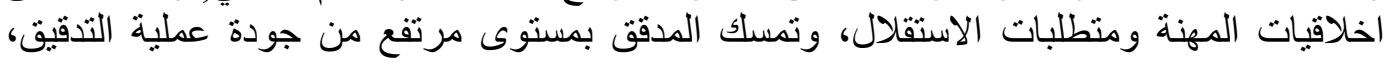

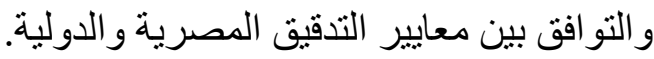


وتحدثت دراسة (Deb, Chakraborty, 2020) عن تحديات التدقيق المالي المحتملة واستر اتيجيات التحول في ظل كوفيد -19، حيث تضاعف تداعة إعيات جائحة كوفيد-19 على التى التقارير

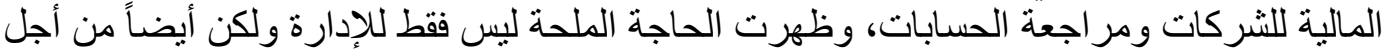

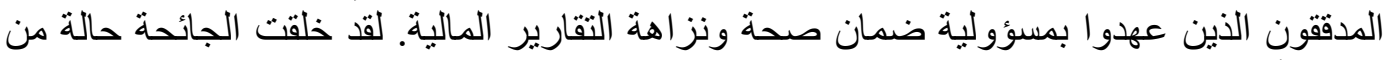
عدم التأكد الكبيرة فيما يتعلق بمبادئ المحاسبة في إعداد البيانات المالية، وكذية وكللك في عملية التئة التدقيق،

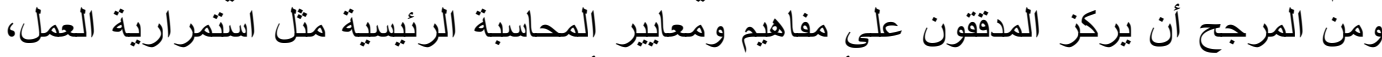

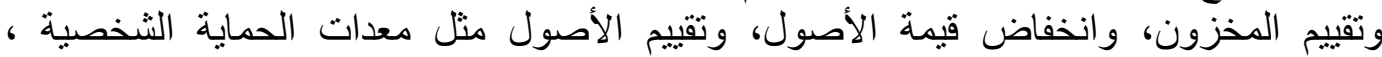

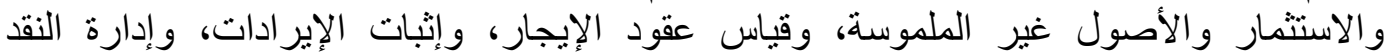

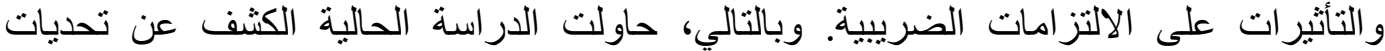

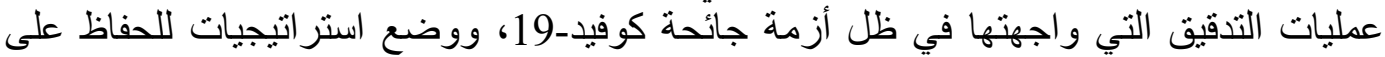
صحة البيانات المالية المدققة ولنية وعدالتها. كما ناقثت در اسة (Joshi, 2020) بعض التحاتية التحديات والآثار المترتبة على التقارير المالية للمحاسبة

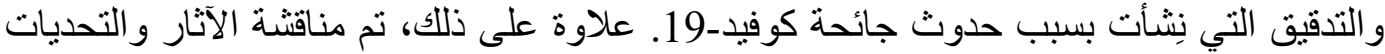

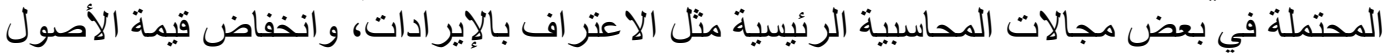

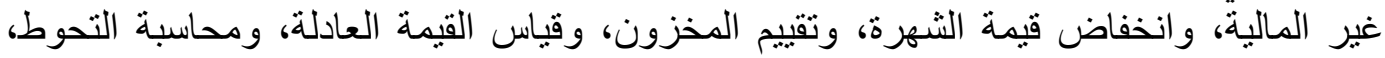

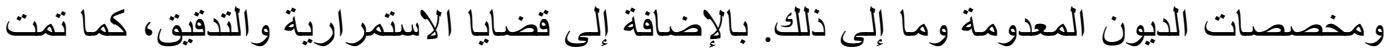

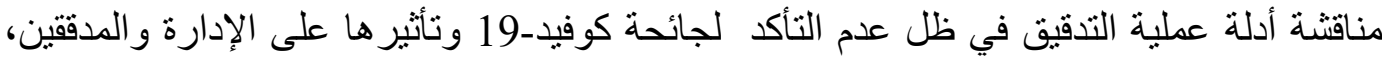

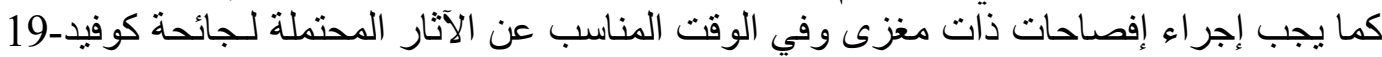

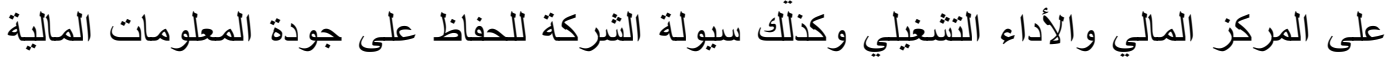

للمستخدمين، ويجب على المدققين ممارسة الثنك المهني أثناء عملية تدقيق أرقام البيانات المالية.

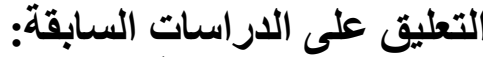

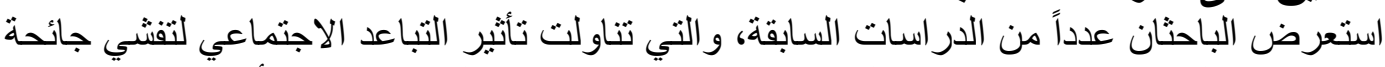
كوفيد 19 على جودة التدقيق، وتتاولت خمسة اعتبار ات رئيسية لجودة التدقيق أثناء الجائحة وهي

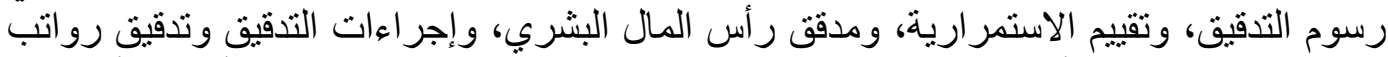

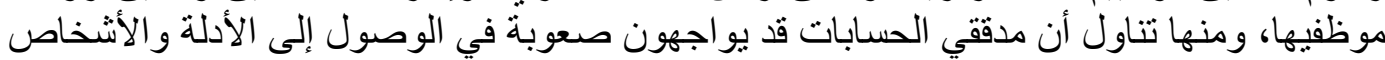

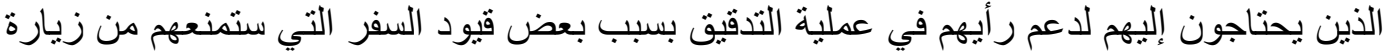

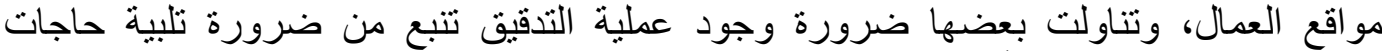

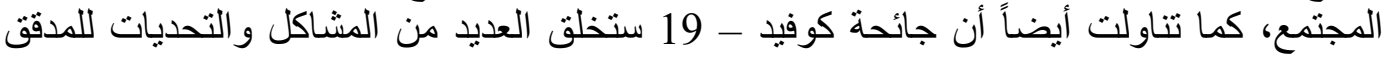

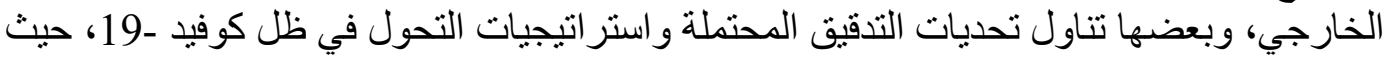

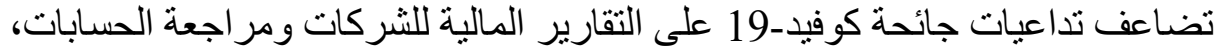
* أوجه الاستفادة من الاراسات السابقة:

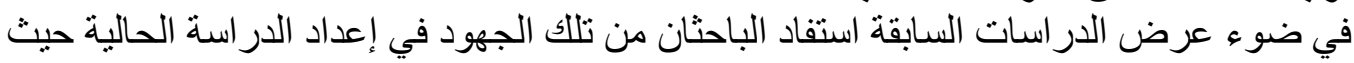

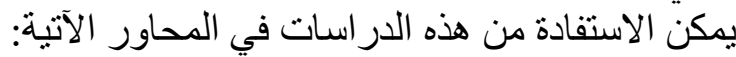

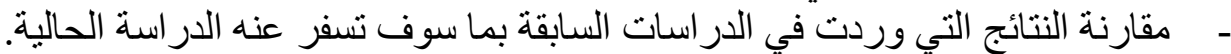
- معرفة الأساليب الإحصائية المناسبة لمعالجة البيانات.

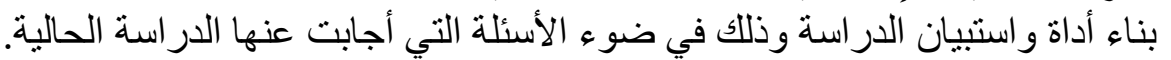
إثر اء الإطار النظري للأر اسة الحالية.

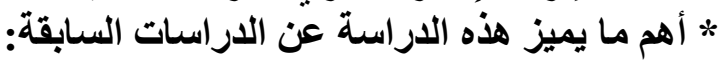

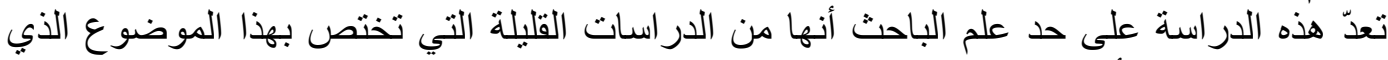

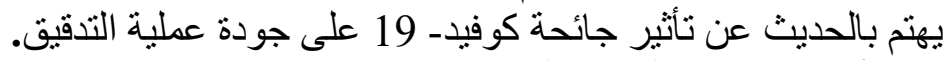
* ما أضافته الار استة الحالية: تناولت هذه الدراسة موضوالهة الداً ميدانياً وعملياً يوضح تأثير جائحة كوفيد- 19 على جودة عملية

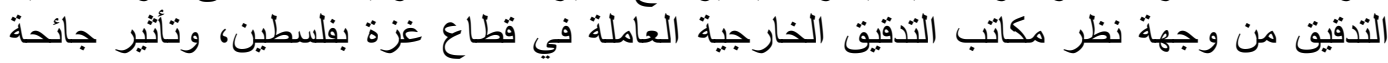

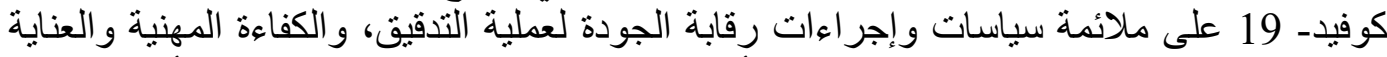
اللازمة لعملية التدقيق، ومدى إدر اك المدقق لأهمية تحقيق الجودة في عملية التدقيق، و أتعاب عملية 
عرف مجلس التقارير المالية في المملكة المتحدة جودة التدقيق هي: "مفهوم ديناميكي، وأن

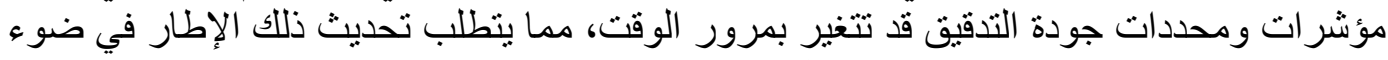

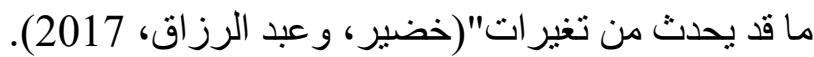

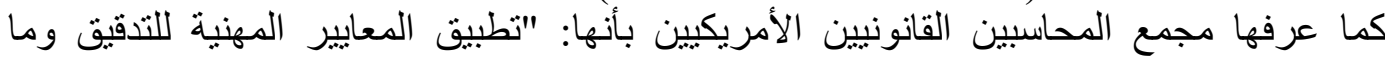

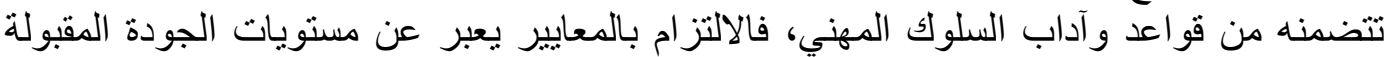

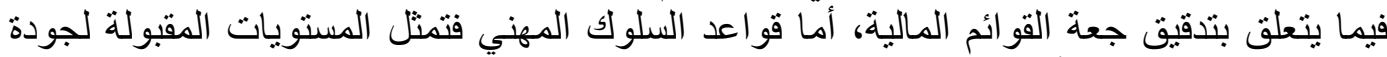

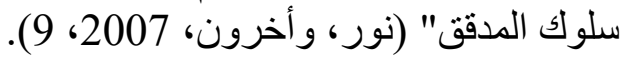

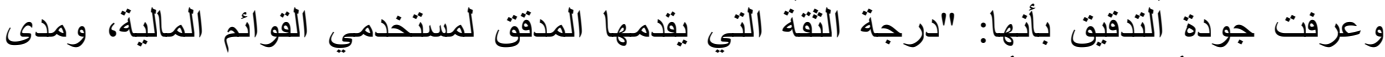

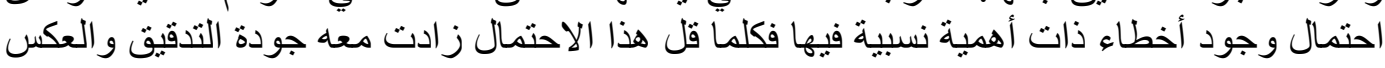

صحيح. (Salehi and Kangarlouei, 2010)

\section{ثانياً تداعيات جائحة كوفيد-19 على مهنة التدقيق:}

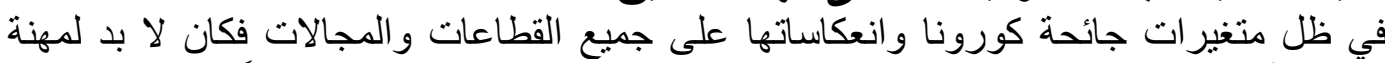

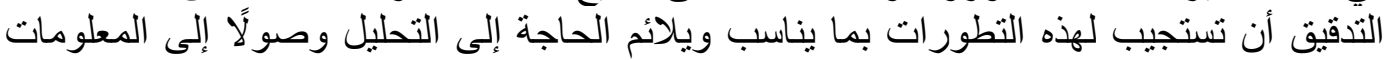

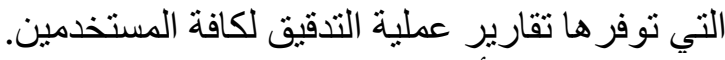

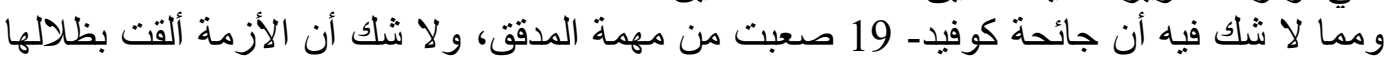

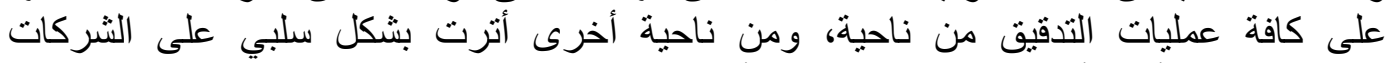

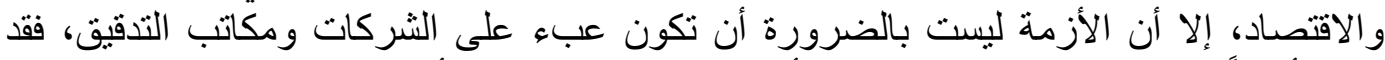

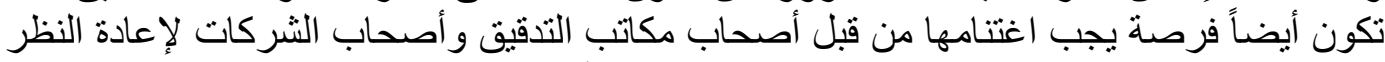

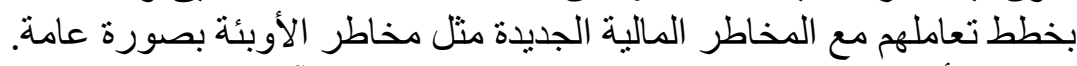

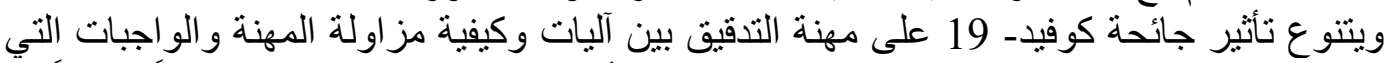

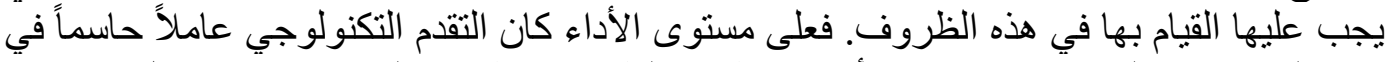

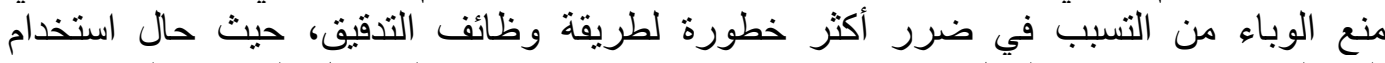

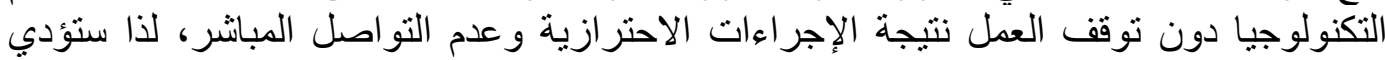

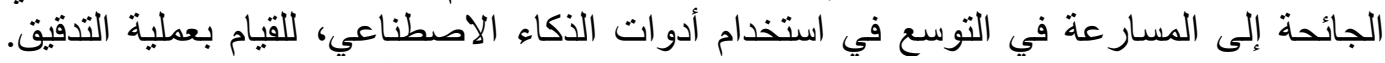

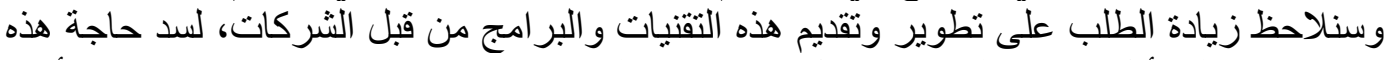

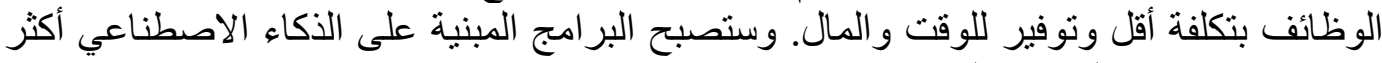

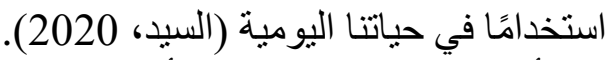

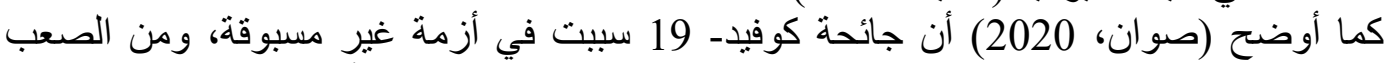

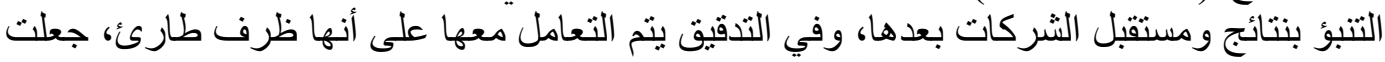

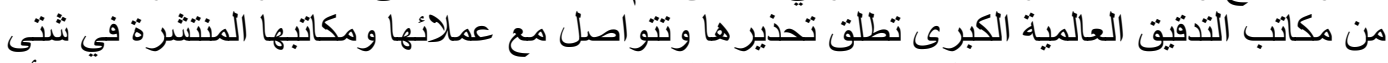

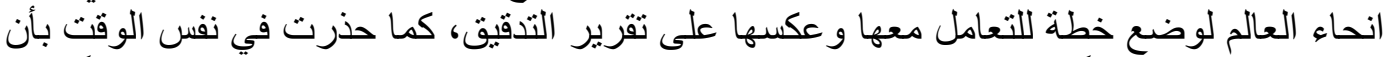

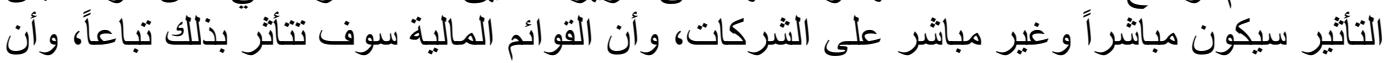

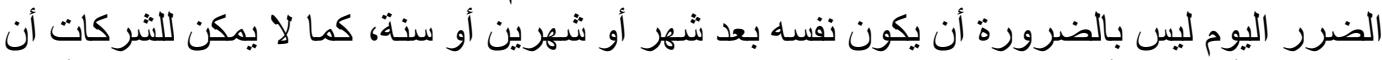

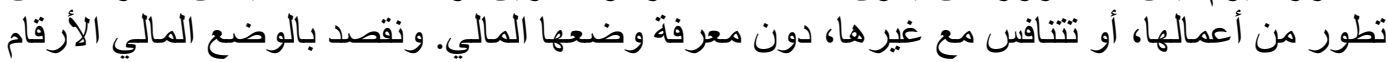

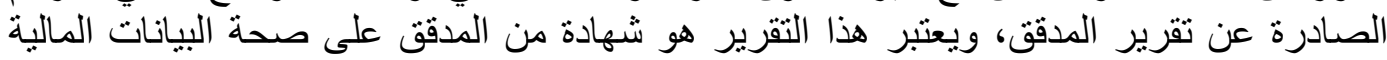

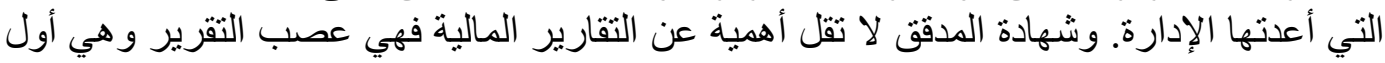

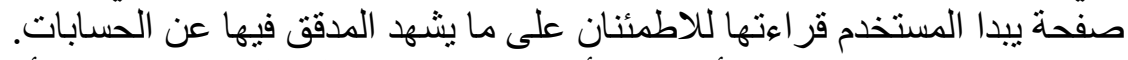

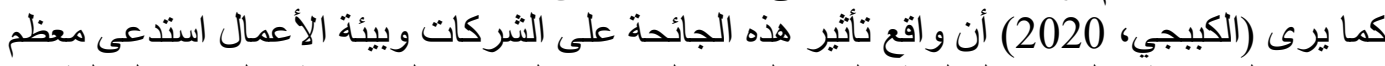

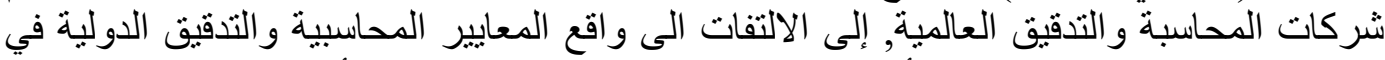

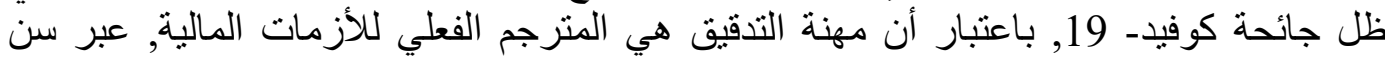

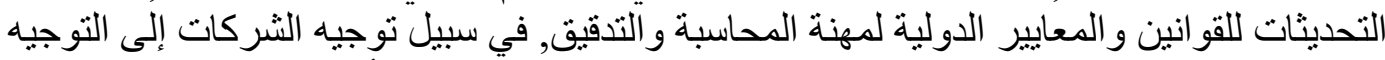

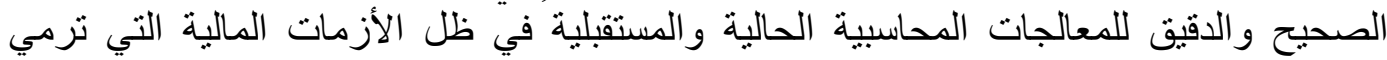

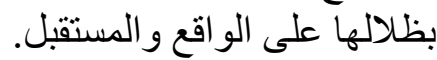
لذا فقد تتاولت شركات المحاسبة والتدقيق العالمية في إصداراتها وتقاريرها المستحدثة الأثار

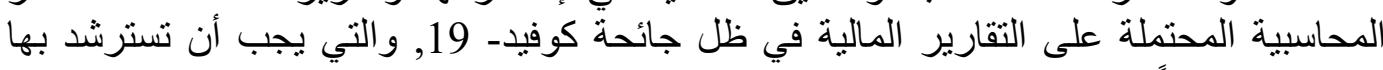
الثركات عموماً في إعدادها للتقارير المالية وكذلك شركات المحاسبة والتدقيق. 
كما أشـارت در اسة (عبدالله، ومحمد، 2020) ان جائحة كورونا اثرت على ألى عمل المدققين، من خلال

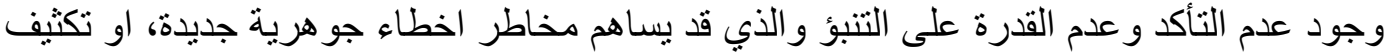

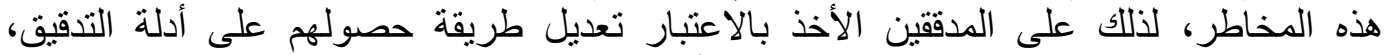

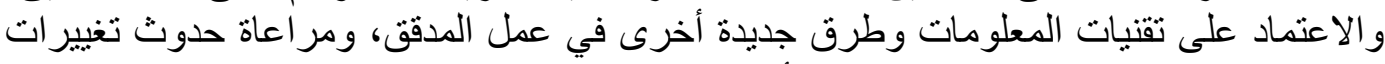

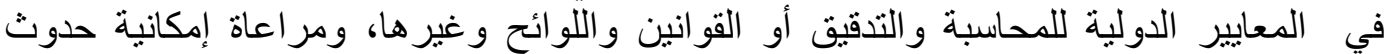

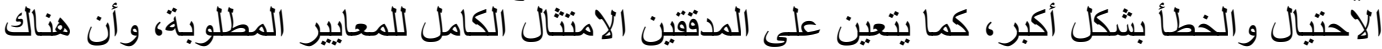

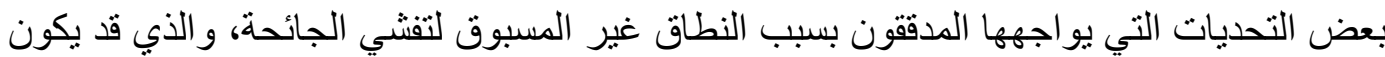
له تأثير سلبي على جودة التدقيق.

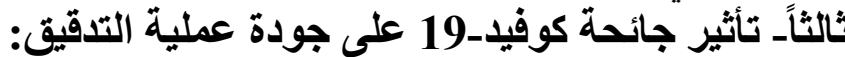

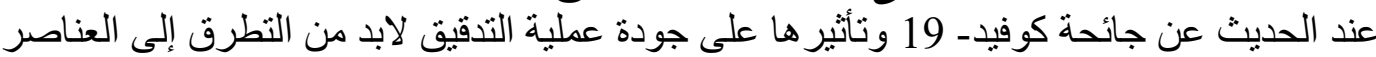

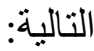

\section{1. ملائمة سياسات وإجراعات رقابة الجودة لعملية التدقيق:}

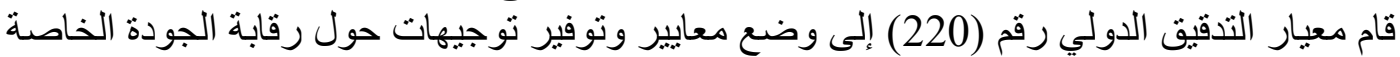

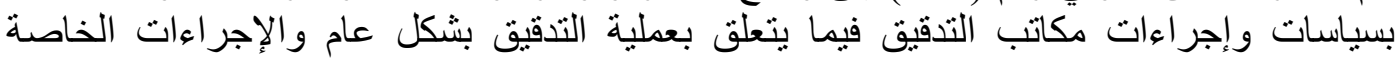

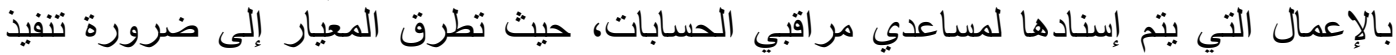

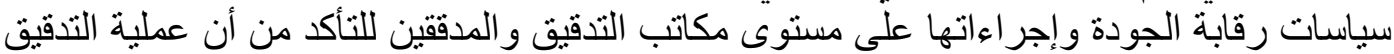

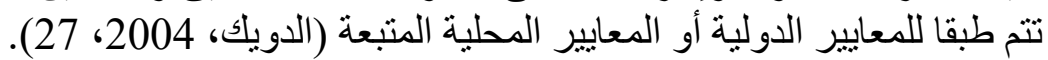
كما نصت الفقرة (8) من معيار التدقيق الدولي رقم (220) على ما يلي (ISAS, 2000, 11):

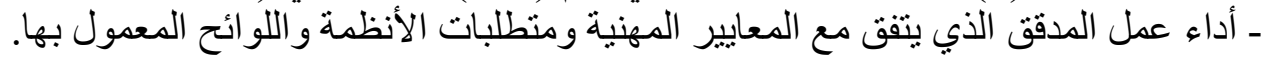

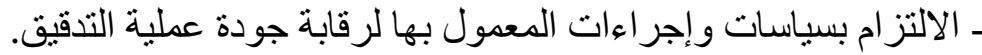

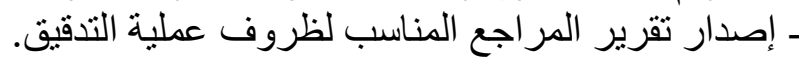
ـ قدرة فريق التدقيق على إثارة الثكوك دون الخدوف الخوف من ردود الأفعال. ـ حقيقة أن الجودة أمر أساسي في تنفيذ عملية المر اجعة.

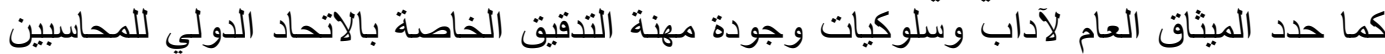

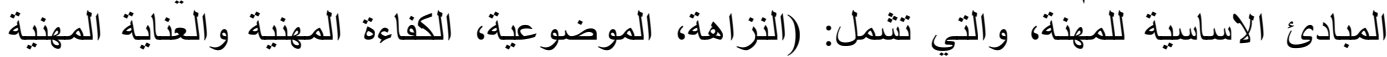
الو اجبة، السرية، السلوك المهني). وأثرت جائحة كوفيد - 19 بشكل كبير على الطريقة التي يتم بها سياسات إجر اءات عملية التدقيق،

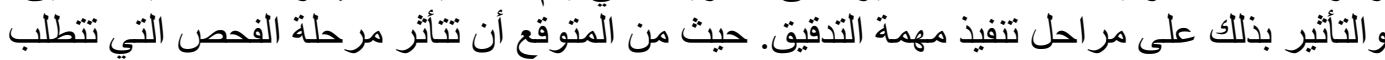

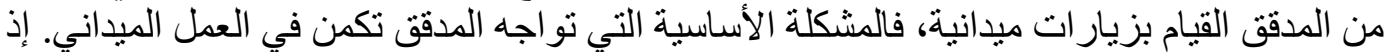

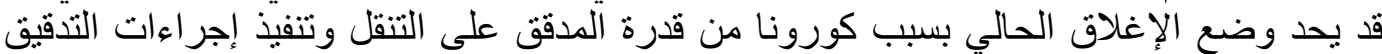

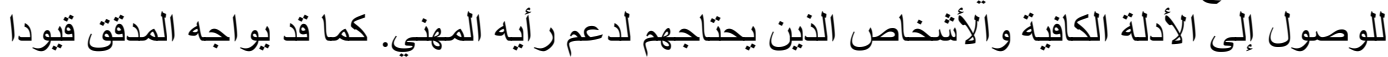

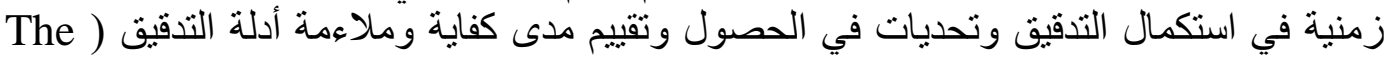

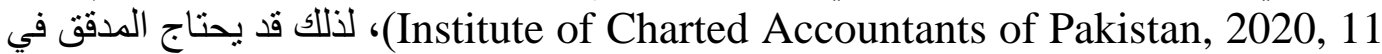

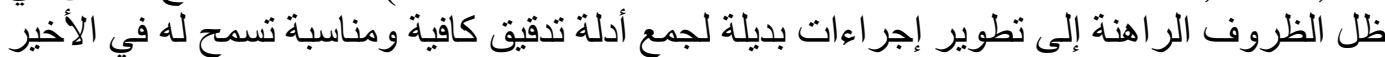

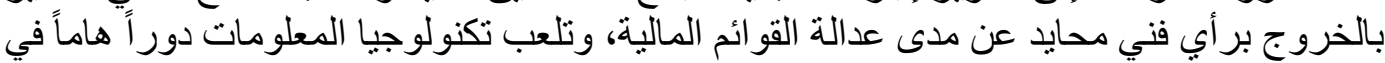
مثل هذه الظروف فهي تساعد على تطبيق استر اتيجيات التباعد الجسدي و العمل عن بعد ما يحد من

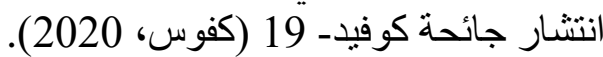

وقد يتغير موقف المدققين على مستوى الإقرار أثناء عملية التدقيق نتيجة حصوله عله على أدلة تدقيق

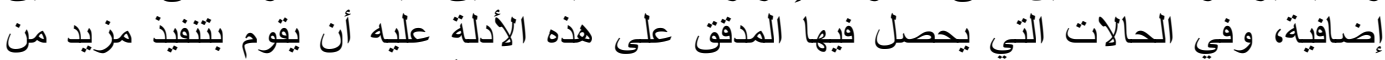

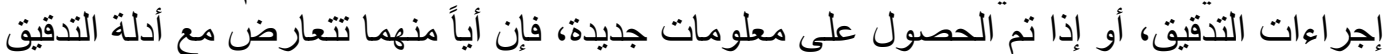

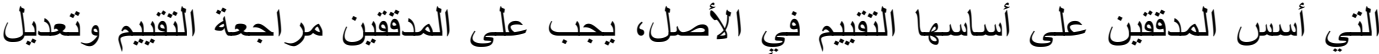

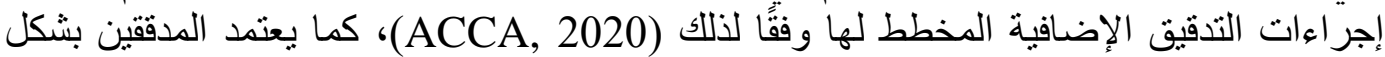

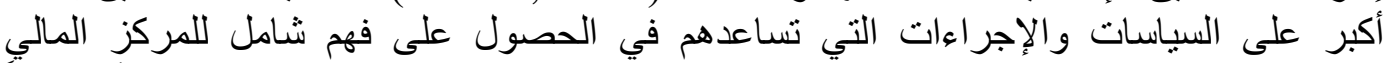

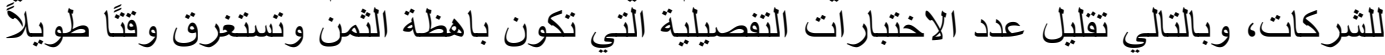
مع الأخذ في الاعتبار أن تتم الاتصالات خلال جائحة كوفيد- 19 عبر رسائل الأل البريد الإلكتروني

(KPMG, 2020) 
ويؤكد الباحثان على ضرورة قيام المدققين باتباع السياسات والإجراءات الملائمة لرقابة جودة

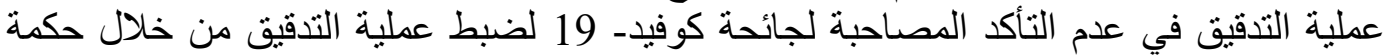

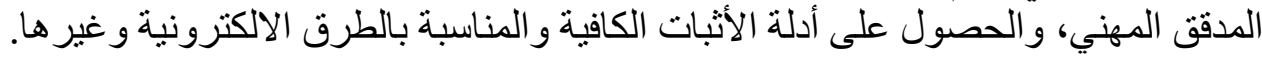

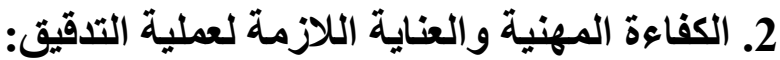

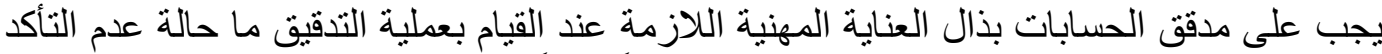

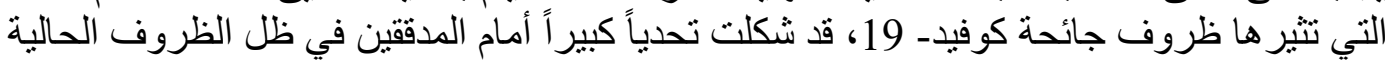

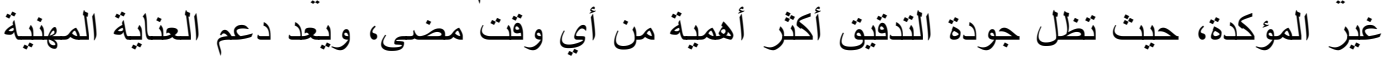

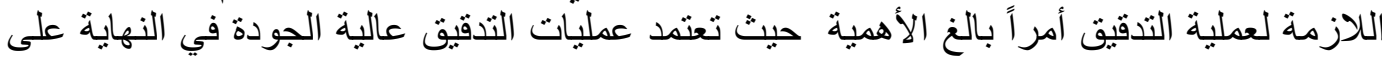

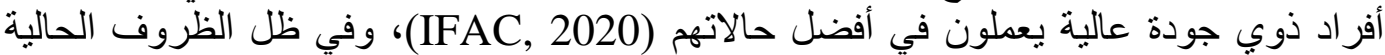

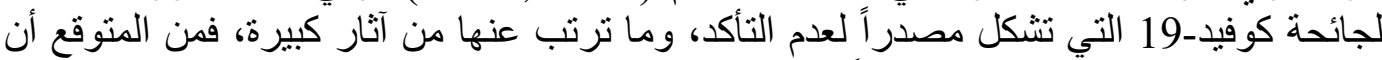

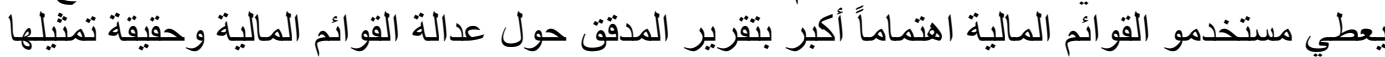

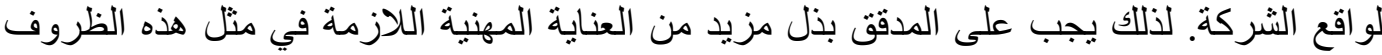

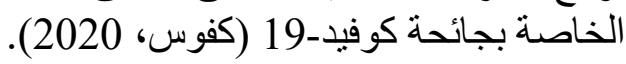

كما يجب على المدققين الالتزام بقو اعد الكفاءة المهنية والعناية اللازمة لعملية التدقيق من خلال ما

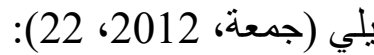
1. المحافظة على المعرفة والمة والمهارات المهنية بالمستوى المطلوب لضمان حصول العملاء على الخدمة المهنية ذات الكفاءة العالية.

2. تأدية المهام بكل عناية وفقا للمعايير الفنية والمهنية المكاية المعمول بها عند تقديم الخدمات المهنية. 3. تتطلب الخدمة المهنية التي تتسم بالكفاءة ممارسة الحكم الصائب في تطبيق المعرفة و المهار ات ات المهنية في أداء تلك الخدمة.

4. يجب ألحصول على الكفاءة المهنية العالية، و المحافظة عليها.

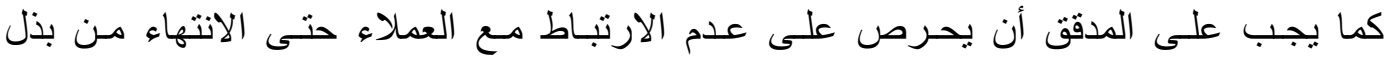

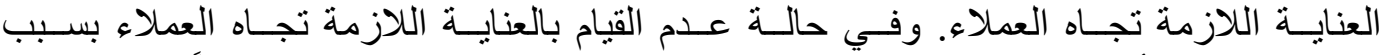

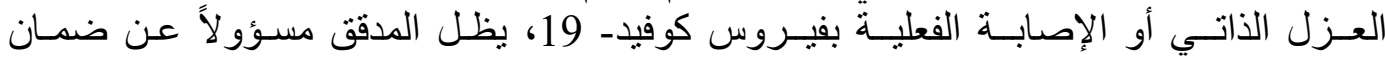

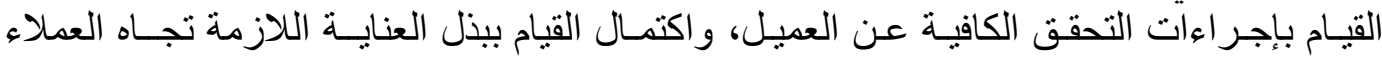

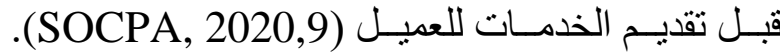

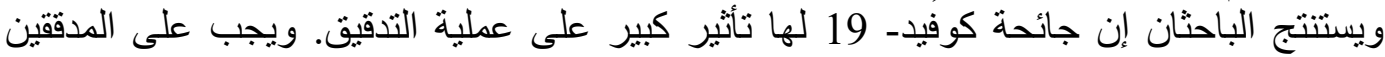

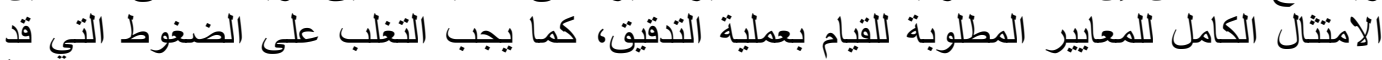

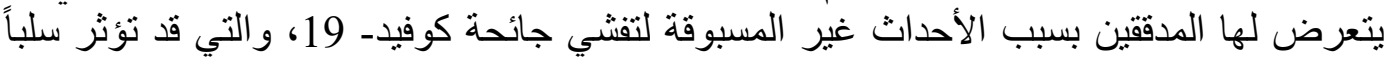
على الكفاءة المهنية و العناية اللازمة لعملية التدقيق، ومن ثم على جودة عملية التدقيق.

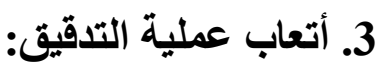

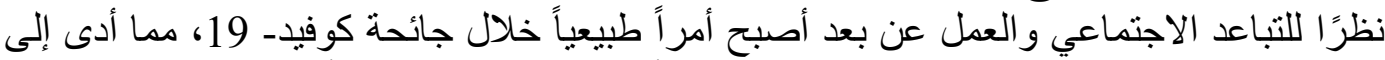

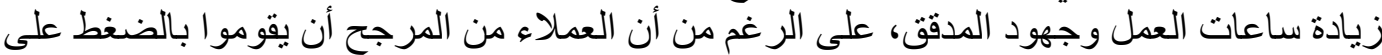

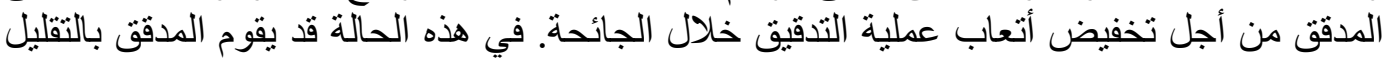

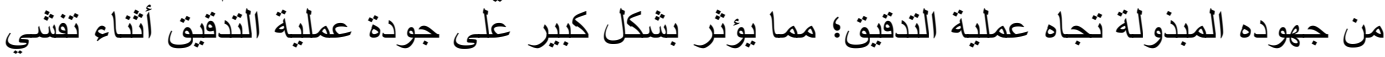
جائحة كوفيد- 19 (Albitar, et al, 2020)، كما تؤثر على الكفاءة المهنية والعناية اللازمة إذاء

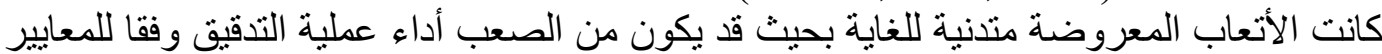

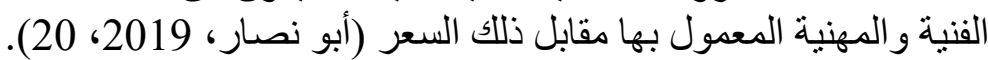

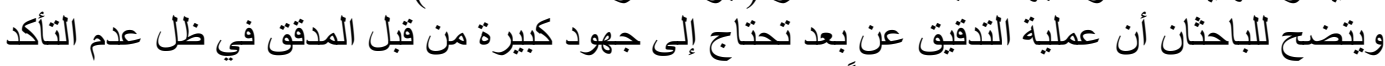

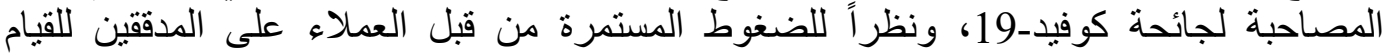

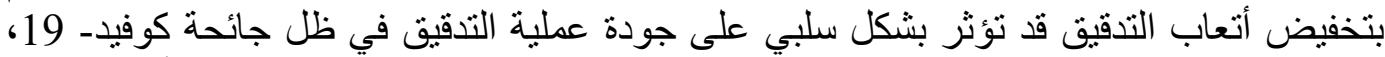

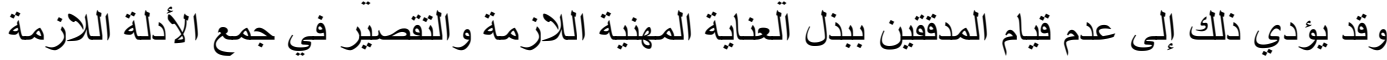
لعملية التدقيق، مما يؤثر على ثقة ومصداقية تقارير المدقق نتاج عملية التدقيق.

4. إدراك المدقق لأهمية تحقيث الجودة في عملية التدقيق:

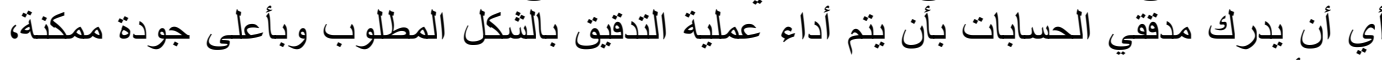
حيث أن المستخدمين الخارجيين للقوائم المالية ينوقعون من مخرجات أن بات عملية التدقيق المتمنلة في 
تقرير المدقق الجودة التامة لأنهم يعتمدون في اتخاذ قراراتهم على هذا التقرير (جبران، 2010)،

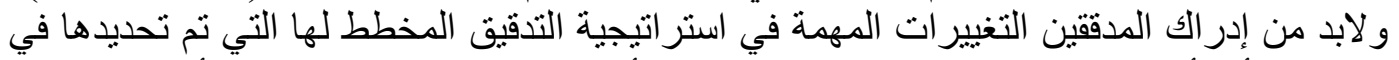

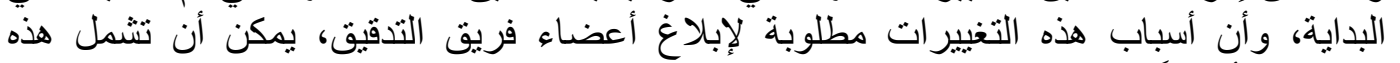

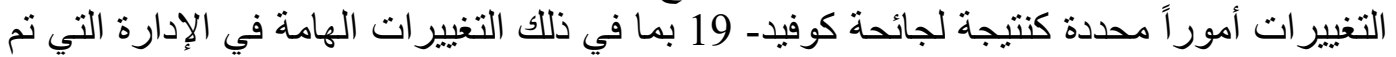

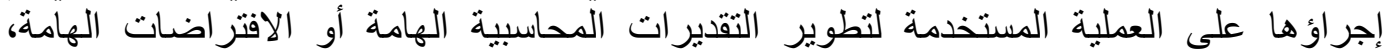

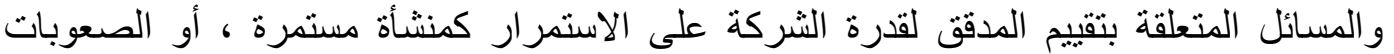

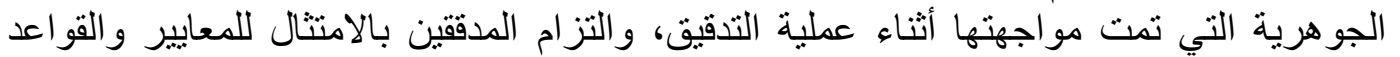

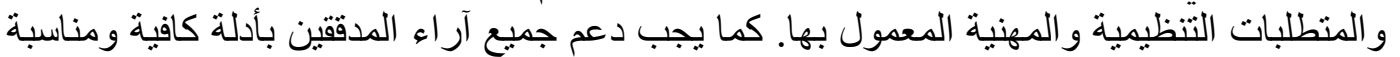
توفر أساساً معقو لاً لهذا الآراء. بالإضافة إلى ذلك، قد تتطلب أهمية تأثير ات جائحة كوفيد- 19

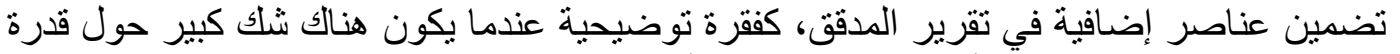

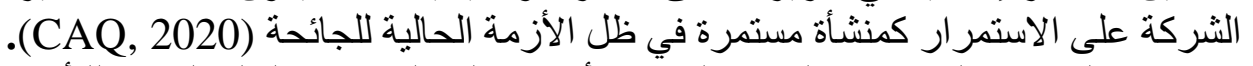

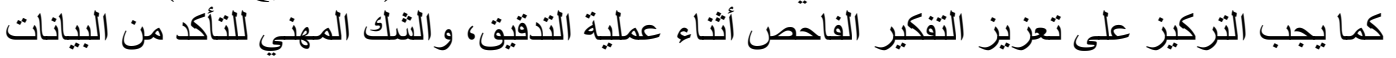

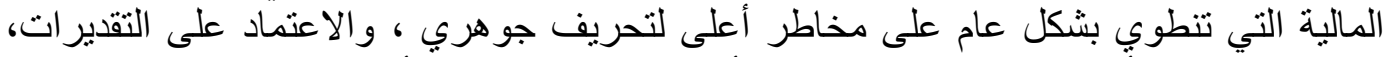

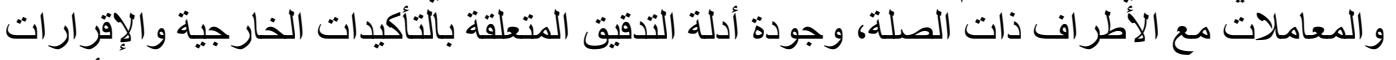

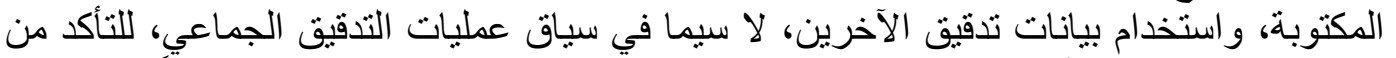

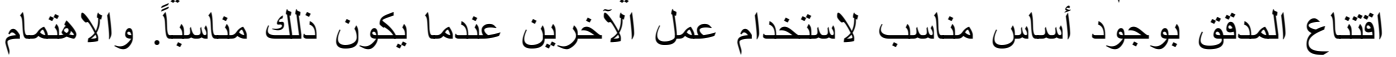

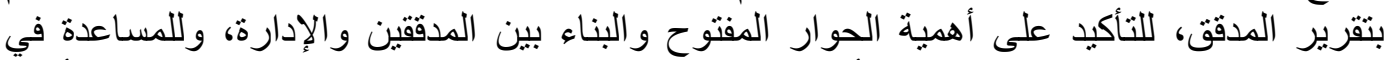

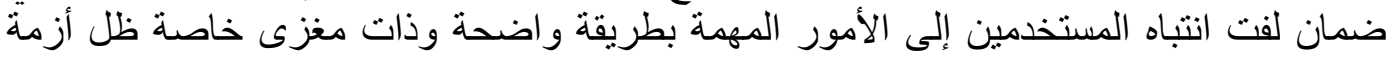

جائحة كوفيد- 19 (IAASB, 2020). وتختلف تصور ات جودة التدقيق بين أصحاب المصالح اعتماداً على مستوى مشاركتهم المباشرة في

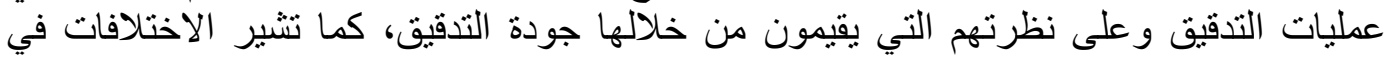

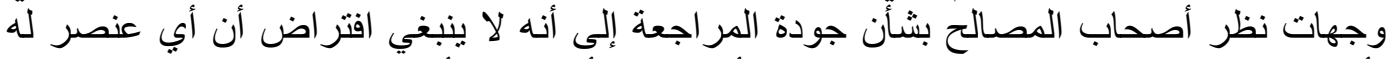

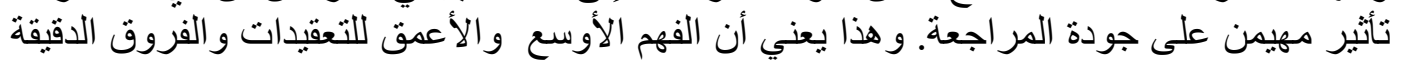

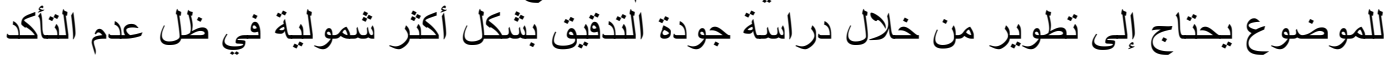

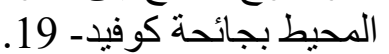

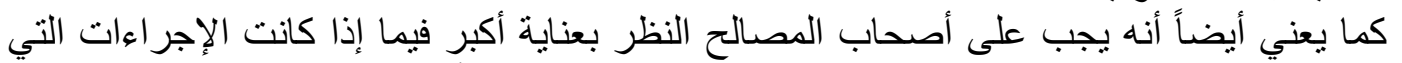

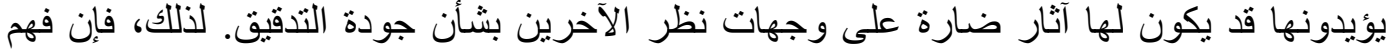
وجهات نظر البعض وكيفية تأثثر إجراءات الفرد على تصورات الآخرين لجودة التدقيق أمر بالغ الأهمية للجهود المبذولة لتحسين جودة التدقيق (IAASB, 2011).

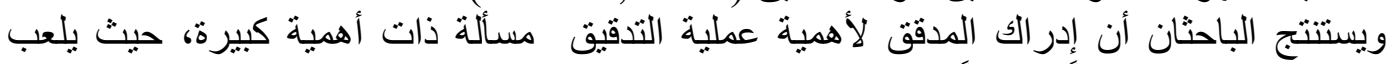

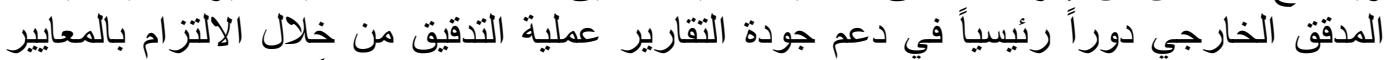

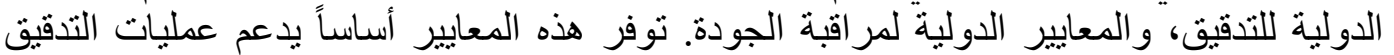

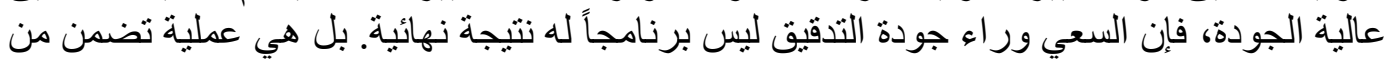

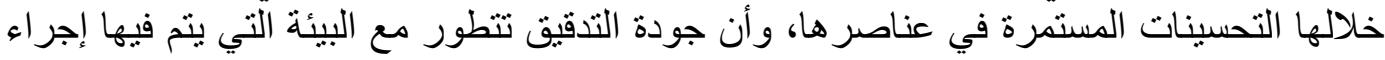

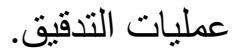

\section{الإطار العملي للاراسة (الدراسة الميدانية):}

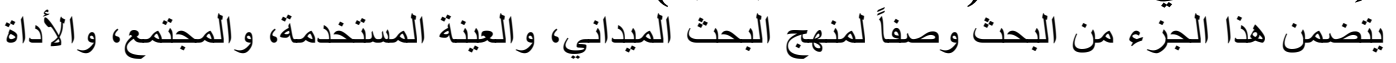

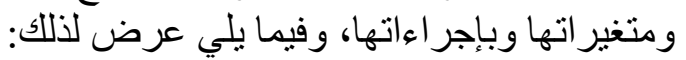

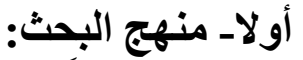

انطلاقاً من طبيعة البحث و الأهداف التي يسعى إليها يستند هذه البحث إلى المنهج الوضه الوصفي

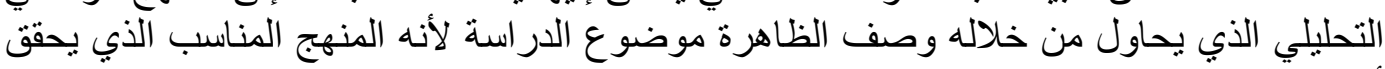
أهداف البحث. ثاتياً مصادر جمع البيانات:

تحقيقاً للهدف الأساسي من البيائات البحث، و المتمثل في التعرف على التي التأثنير المحتمل لجائحسة كوفيد 19

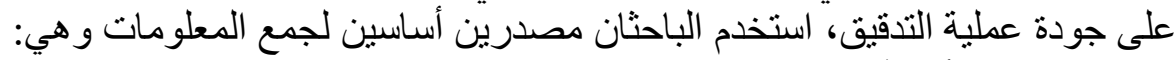

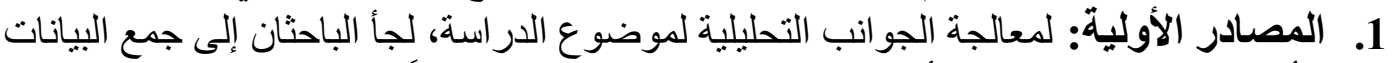

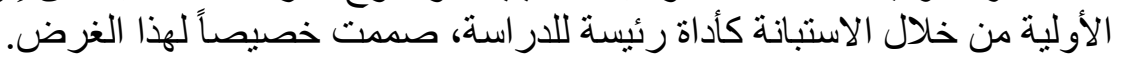




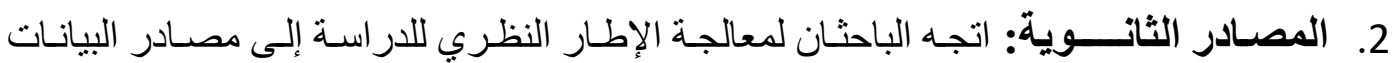

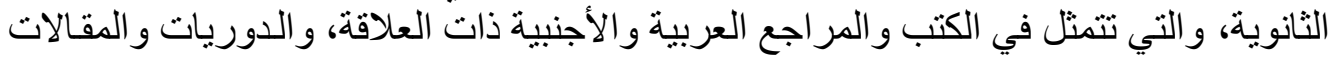

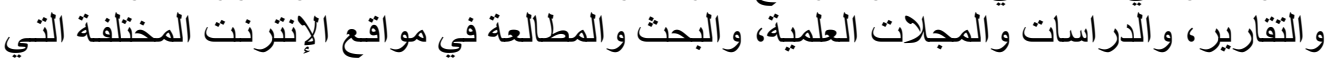

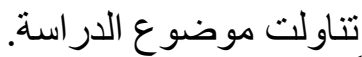

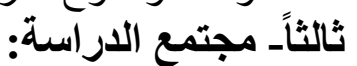

بناءً على مشكلة الدراسة وأهدافها فإن المجتمع المستهدف يتمثل في مكاتب تدقيق

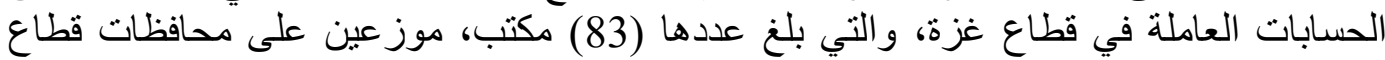

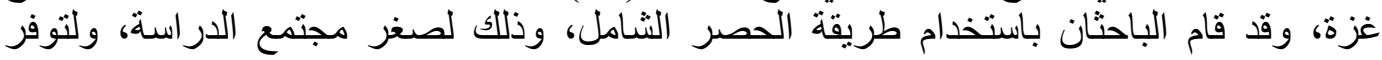

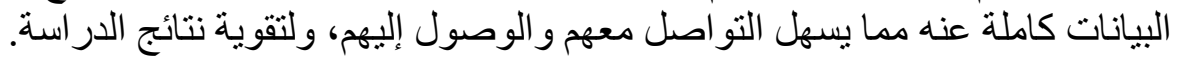

\section{رابعاً_ العينة الاستطلاعية:}

قام الباحثان بتوزيع الاستلاعية عينة استطلاعية حجمها (30) استبانة باستخدام طريقة العينة

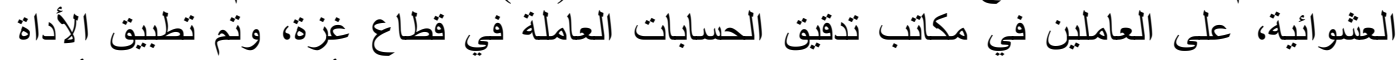

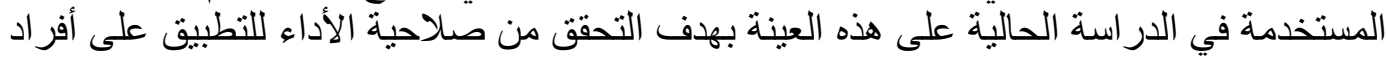

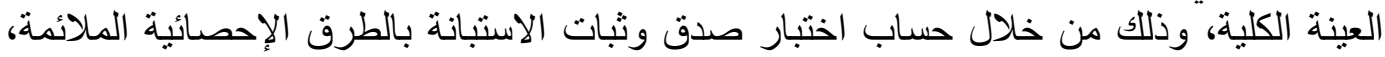
وقد تم استبعادهم من عينة الدراسة التي تم التطبيق عليها أي لم ينم إعادة استخدام هذه العينة.

\section{خامساً العينة الفعلية(الميدانية):}

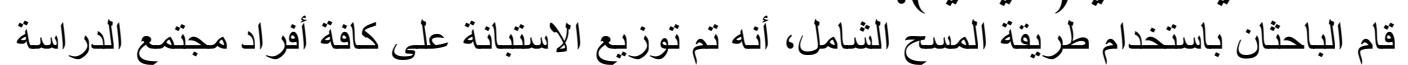

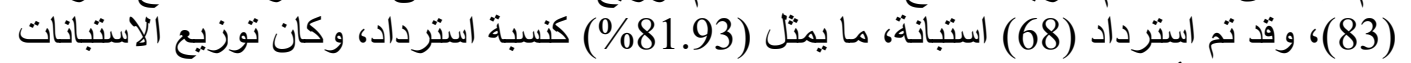

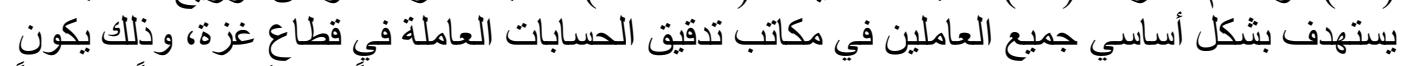

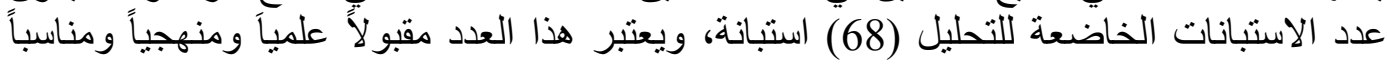

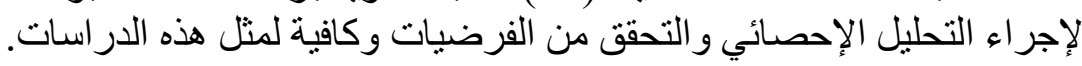

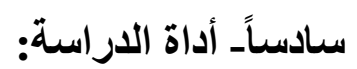

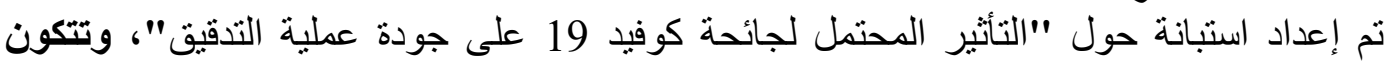

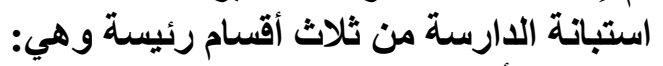

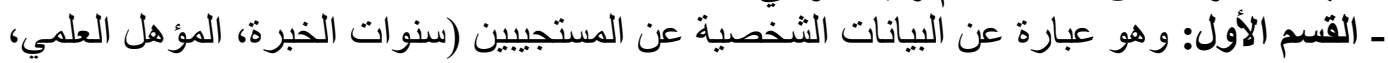

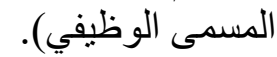
ـ القسم الثاني: وهو عبارة على عن جودة عملية التدقيق, ويتكون من (27) فقرة, موزع على أربعة * المجال الأول: ملائمة سياسـات وإجراءات رقابة الجاتية الجودة لعملية التدقيق ويتكون من (7) فقرات.

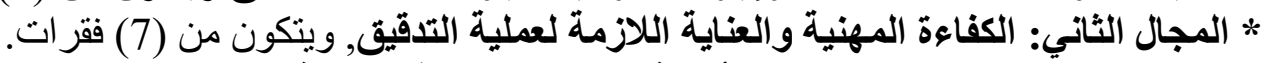

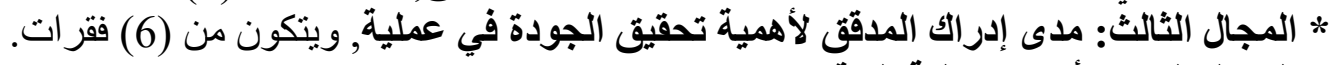

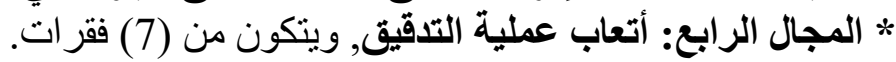

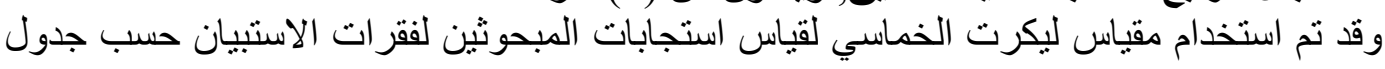

رقم (1):

جدول رقم(1): درجات مقياس ليكرت الخماسي المبي

\begin{tabular}{|c|c|c|c|c|c|c|}
\hline \multirow{2}{*}{ الموافقة } & \multicolumn{2}{|c|}{ الوزن النسبي } & \multicolumn{2}{|c|}{ المتوسط الحسابي } & \multirow{2}{*}{ الرقيمي } & \multirow{2}{*}{ الاستجابة } \\
\hline & إلى & من & إلى & من & & \\
\hline قليلة جذاً & أقل من 36.00 & 20.00 & أقل من 1.80 & 1.00 & 1 & غير موافق بشدة \\
\hline قليلة & أقل من 52.00 & 36.00 & أقل من 2.60 & 1.80 & 2 & غير موافق \\
\hline متوسطة & أقل من 68.00 & 52.00 & أقل من 3.40 & 2.60 & 3 & متوسطة \\
\hline كبيرة & أقل من 84.00 & 68.00 & أقل من 4.20 & 3.40 & 4 & موافق \\
\hline كبيرة جداً & 100.00 & 84.00 & 5.00 & 4.20 & 5 & موافق بشدة \\
\hline
\end{tabular}

ولتحديد مستوي المو افقة على كل فقرة من الفقرات، وكل بعد، وكل مجـال ضـمن أداة الدراسـة، تم

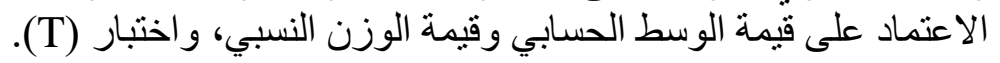


اعتمد الباحثان على تدريج خماسي متدرج لقياس أراء المحكمين عند تحكيم فقرات

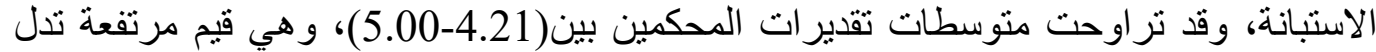

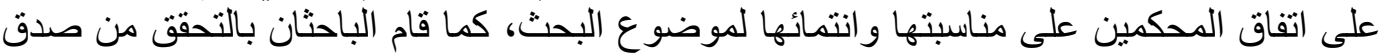

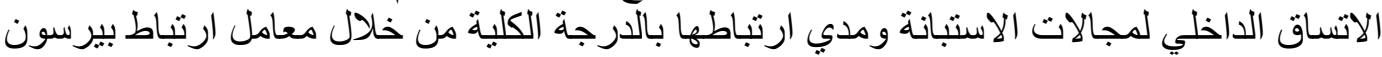

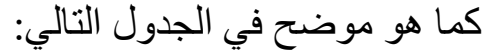
جدول (2) معامل الارتباط بين كل فقرة من فقرات مجالات " الاستبانة " والدرجة الكلية للمجال

\begin{tabular}{|c|c|c|c|c|}
\hline للمجامل الارتباط & للمجال الثارثباط & للمجامل الارتباط & للمجال الأوتباط & م. \\
\hline أتتعـــــاب عمليـــــة & 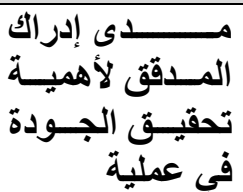 & لعلعلية التدقية اللازمة & 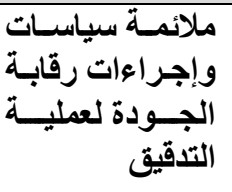 & \\
\hline $.870 * *$ & $.764 * *$ & $.781^{* *}$ & $.562^{* * *}$ & 1 \\
\hline $.832 * *$ & $.909 * *$ & $.820^{* *}$ & $.608^{* *}$ & 2 \\
\hline $.811 * *$ & $.894 * *$ & $.871^{* *}$ & $.570^{* *}$ & 3 \\
\hline $.856 * *$ & $.733 * *$ & $.774^{* *}$ & $.493^{* *}$ & 4 \\
\hline $.633 * *$ & $.796 * *$ & $.845^{* *}$ & $.548^{* *}$ & 5 \\
\hline $.779 * *$ & $.756 * *$ & $.773^{* *}$ & $.634^{* *}$ & 6 \\
\hline $.760 * *$ & & $.792^{* *}$ & $.413^{* *}$ & 7 \\
\hline
\end{tabular}

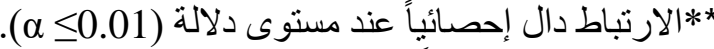

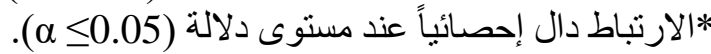

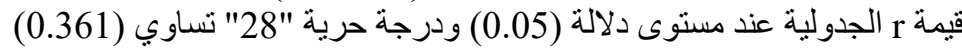

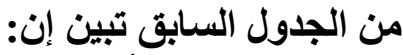

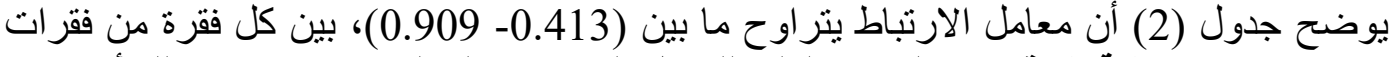

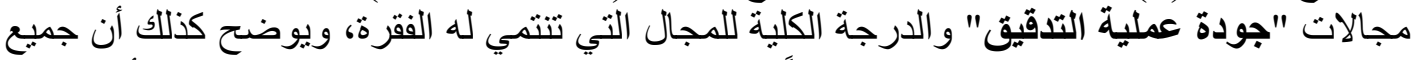

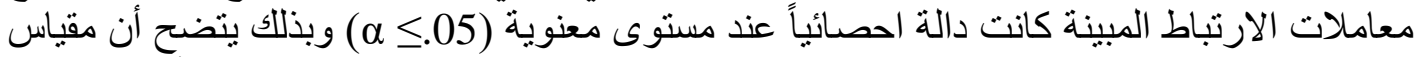
جودة عملية التدقيق تتسم بدرجة جيدة من صدق الاتساق الداخلي، ولذلك تعتبر أداة الدراسة التانة

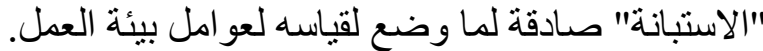

2tructure Validity الصدق البنائي يعد الصدق البنائي أحد مقاييس صدق الأداة الذي يقيس مدى تحقى الأهداف التي تريد الأداة الوصول إليها، ويبين مدى ارتباط كل مجال من مجالات الدراسة بالآلدرجة الكلية لفقرات

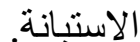

جدول (3) معامل الارتباط بين درجة كل مجال من مجالات الاستبانة والدرجة الكلية للاستبانة

\begin{tabular}{|c|c|c|}
\hline الاحتمالية (Sig. القيمة & معامل بيرسون & 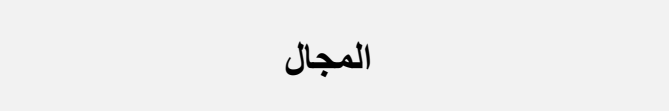 \\
\hline .000 & $.862 * *$ & ملائكة سياسات و إجر اءات رقابة الجودة لعملية التتقيق. \\
\hline .000 & $.957 * *$ & الكفاءة المهنية والعناية اللازمة لعملية التدقيق. \\
\hline .000 & $.955^{* *}$ & مدى إدر اك المدقق لأهمية تحقيق الجودة في عملية. \\
\hline .000 & $.947 * *$ & أنعاب عملية التدقيق. \\
\hline
\end{tabular}

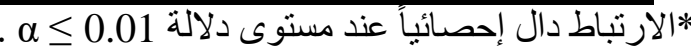

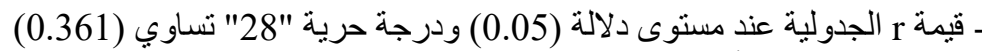

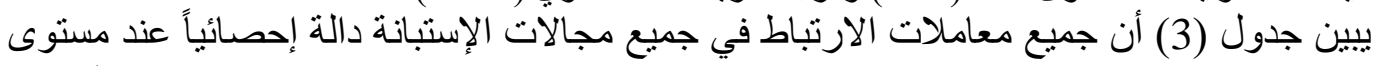

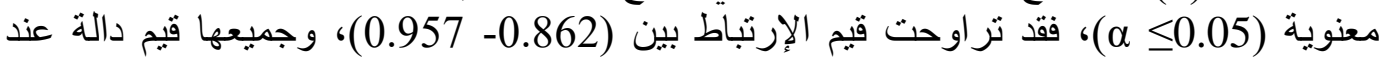




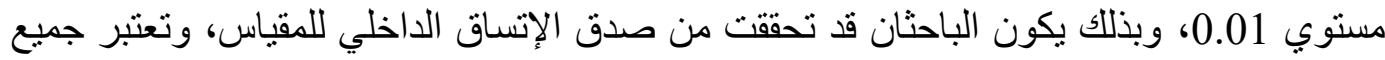
مجالات الإستبانة صادقه لما وضعت لقياسه، وييقي المقياس في صورته النهان النهائية يتكون من (27) فقرة.

تثامناً ثبات الإستبانة Reliability: يقصد بثبات الاستبانة هو أن يعطي الاستبيان نفس النتائج إذا أعيد نطبيقه عدة مرات متتالية،

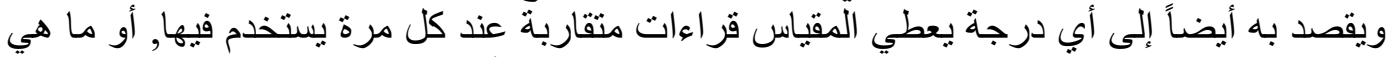

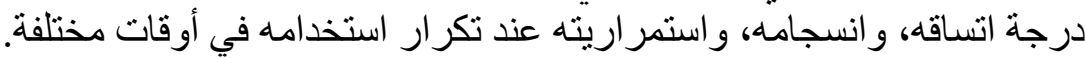

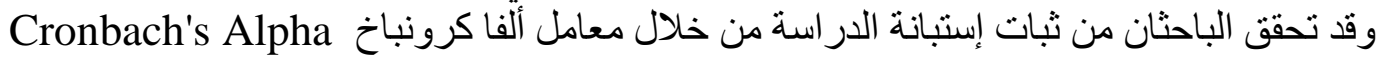
Coefficient

\section{جدول (4) معامل ألفا كرونباخ لقياس ثبات الإستبانة}

\begin{tabular}{|c|c|c|c|c|c|}
\hline \multicolumn{2}{|c|}{ طريقة التجزئة } & \multirow[b]{2}{*}{ الأتيدق } & \multirow{2}{*}{ كرونباخ ألفا } & \multirow{2}{*}{ الفقرات - ات } & \multirow[b]{2}{*}{ المجال } \\
\hline 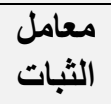 & الارتباط & & & & \\
\hline 0.772 & 0.637 & 0.899 & 0.808 & 7 & 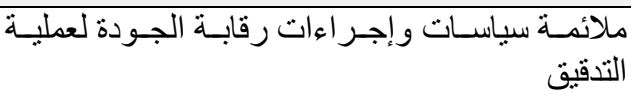 \\
\hline 0.868 & 0.805 & 0.953 & 0.909 & 7 & الكفاءة المهنية و العناية اللازمة لعملية التدقيق \\
\hline 0.808 & 0.686 & 0.944 & 0.892 & 6 & مدى إدرآك المدقق لأهمية تحقيق الجودة في عملية \\
\hline 0.783 & 0.713 & 0.952 & 0.907 & 7 & أتعاب عملية التدقيق \\
\hline 0.929 & 0.871 & 0.982 & 0.964 & 27 & جميع المجالات معاً \\
\hline
\end{tabular}

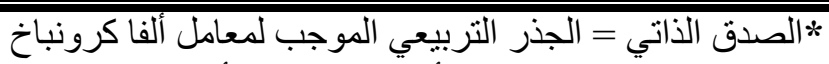

واضح من النتائج الموضحة في جدول (4) أن قيمة معامل ألفا كرونباخ مرتفعة لكل مجان مجال حيث

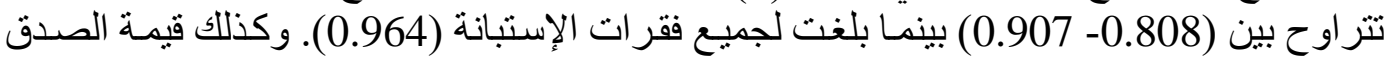

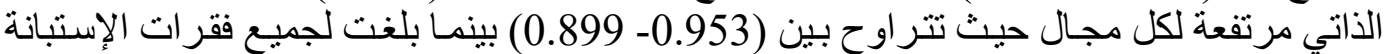

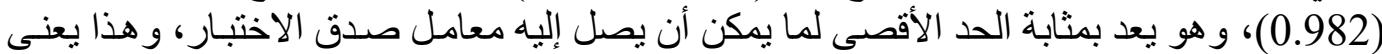

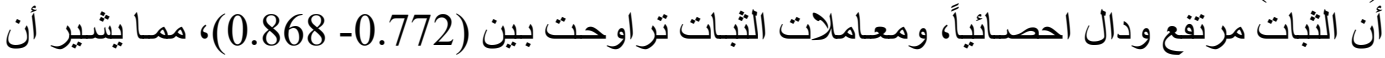

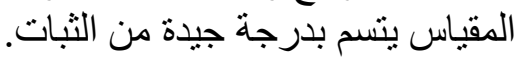

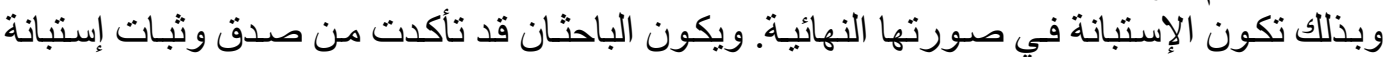
الدر اسة مما يجعلها على ثقة تامة بصحة الإستبانة، وصلاحيتها لتحليل النتائج، و الإجابة على أسئلة

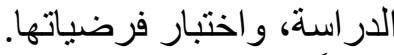

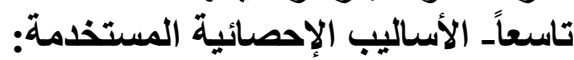
تم تفريغ وتحليل الإستبانة من خـلال برنـامج التحليل الإحصـائي .(SPSS) Social Sciences

ـ اختبار التوزيع الطبيعي Sormality Distribution Test

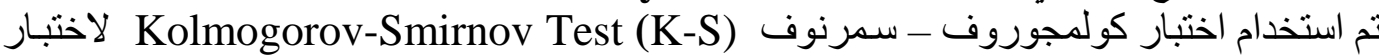

ما إذا كانت البيانات تتبع التوزيع الطبيعي من عدمه، وكانت النتائج كما هي مبينة في جدول (5) (5). جدول (5) يوضح نتائج اختبار التوزيع الطبيعي

\begin{tabular}{|c|c|c|}
\hline القيمة الاحتمالية & قيمة الاختبار & 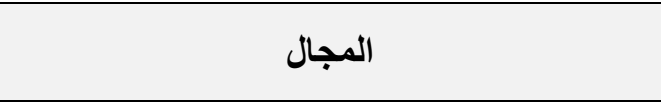 \\
\hline .237 & 1.032 & ملائمة سياسات وإجر اءات رقابة الجودة لعملية التدقيق \\
\hline .156 & 1.129 & الكفاءة المهنية و العناية اللازمة لعملية التدقيق \\
\hline .126 & 1.472 & مدى إدر الك المدقق لأهمية تحقيق الجودة في عملية \\
\hline .350 & .932 & أنعاب عملية التدقيق \\
\hline .240 & 1.029 & جميع مجالات الاستبانة معاً \\
\hline
\end{tabular}




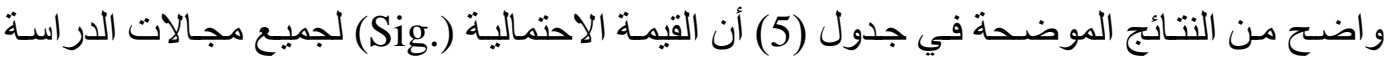

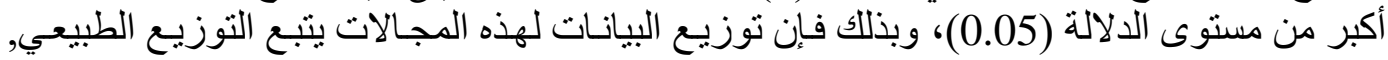

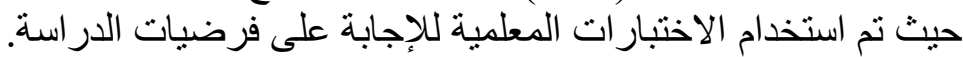
وقد تم استخدام الأدوات الإحصائية التالية:

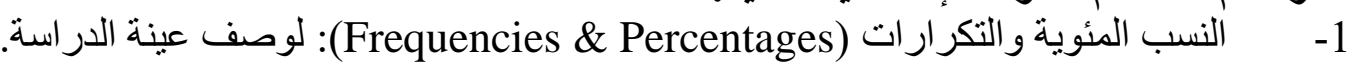

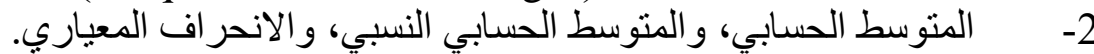

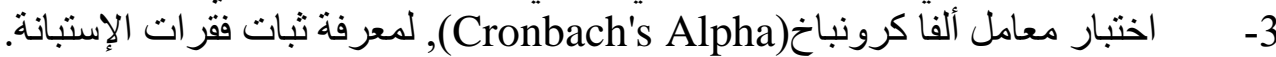

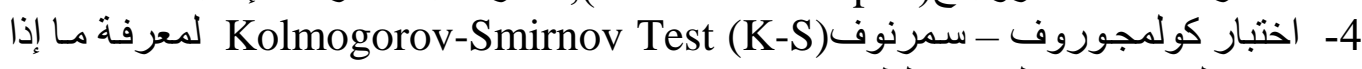
كانت البيانات تتبع التوزيع الطبيعي من عدمانه.

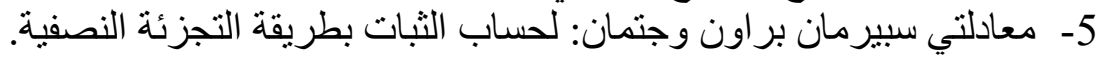

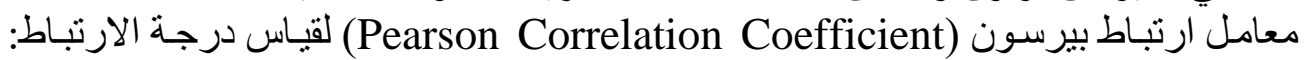

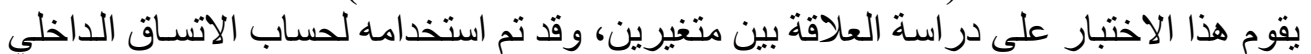

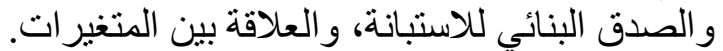

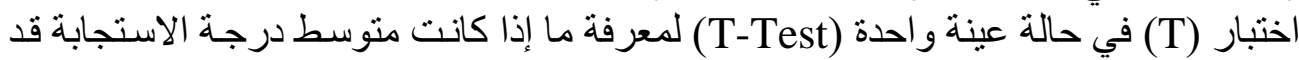

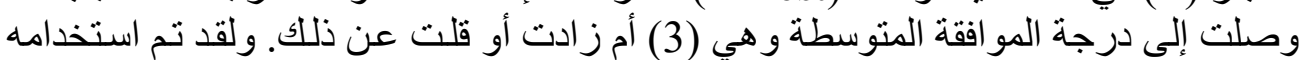
للتأكد من دلالة المتوسط لكل فقرة من فقر آلات الاستبانة. 8- لمعرفة ما إذا كان هناك فروقات ذات الات دلالة إحصائية بين ثلاث مجمو عات التات أو أكثر من البيانات.

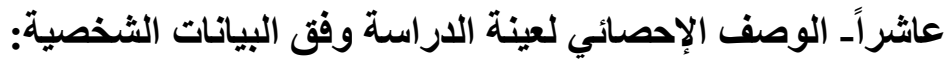

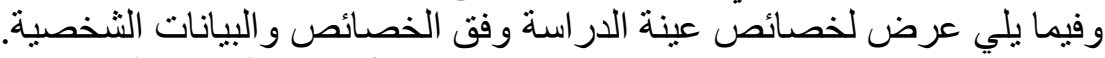
جدول رقم (6) توزيع أفراد عينة الاراسة

\begin{tabular}{|c|c|c|c|}
\hline النسبة \% & 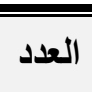 & الفئة & البيانات \\
\hline 16.2 & 11 & أقل من 5 سنو ات & \multirow{3}{*}{ سنوات الخبرة } \\
\hline 35.3 & 24 & من 5 سنوات إلى 15 سنة & \\
\hline 48.5 & 33 & أكثر من 15 سنه & \\
\hline$\% 100$ & 68 & \multicolumn{2}{|l|}{ المجموع } \\
\hline 83.8 & 57 & مدقق حسابات & \multirow{3}{*}{ الوظيفي } \\
\hline 5.9 & 4 & شريك الددقق & \\
\hline 10.3 & 7 & مدير مكتب تدقيق & \\
\hline$\% 100$ & 68 & \multicolumn{2}{|l|}{ المجموع } \\
\hline 57.4 & 39 & بكالوريوس & \multirow{3}{*}{ المؤهل العلمي } \\
\hline 26.5 & 18 & ماجستير & \\
\hline 16.2 & 11 & دكتوراه & \\
\hline$\% 100$ & 68 & المجموع & \\
\hline
\end{tabular}

بيين من الجدول (6) السابق:

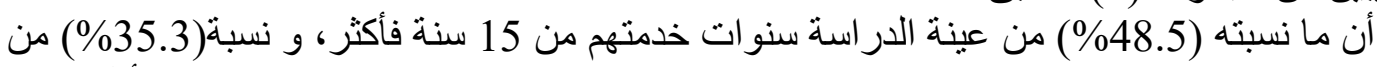

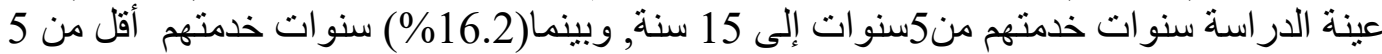

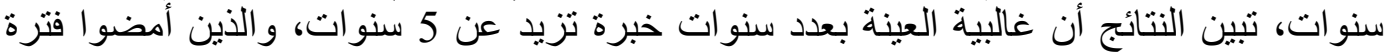

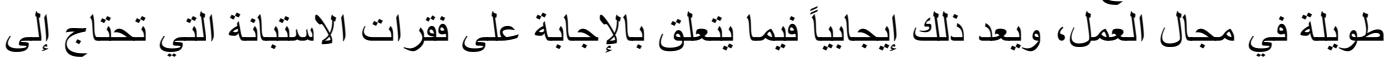


تللك الخبرة، و هذا يدل على أنهم يتمتعون بسنوات خبرة عالية ومتنو عة(قليلة، ومتوسطة، وكبيرة)،

بالتالي يكن لدى أفر اد عينة الدر اسة القدرة و الكفاءة اللازمنين لإظهار منطقية نتائج الدر استة

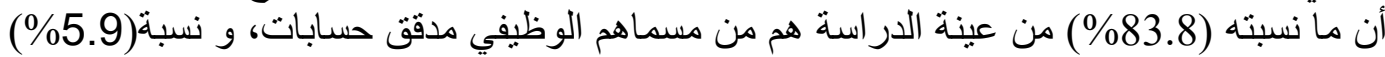

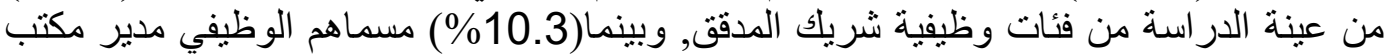

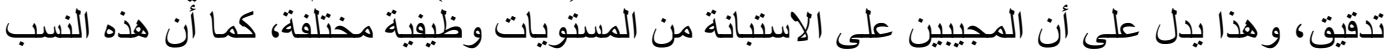

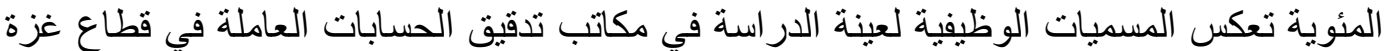

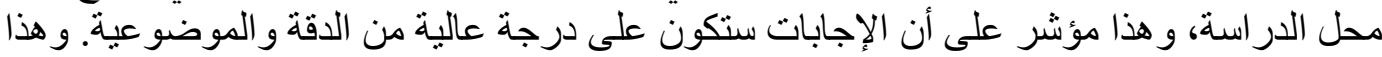

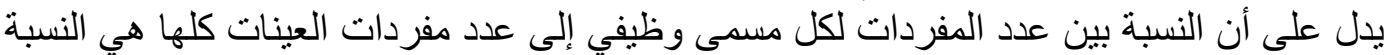

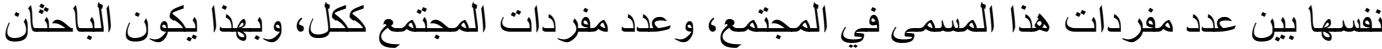

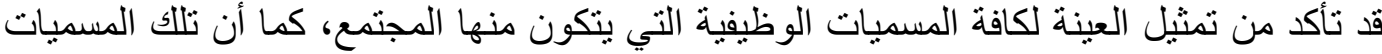

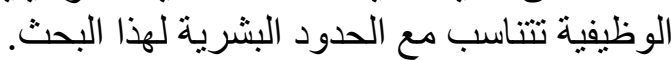

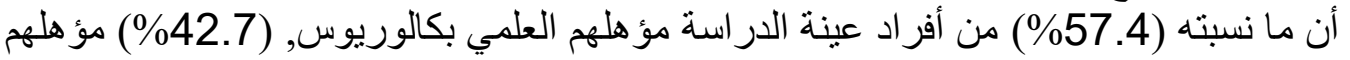

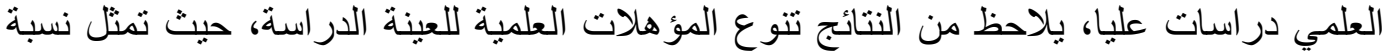

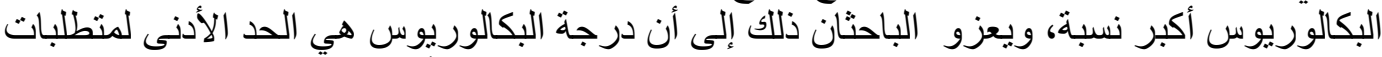

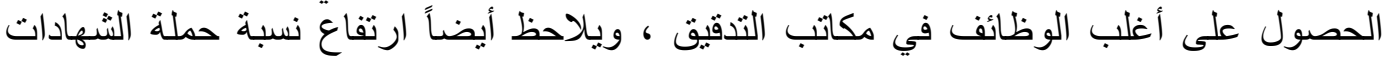

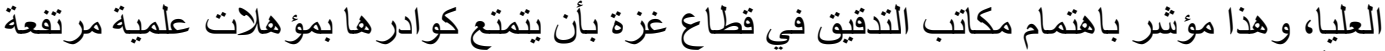

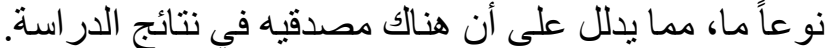

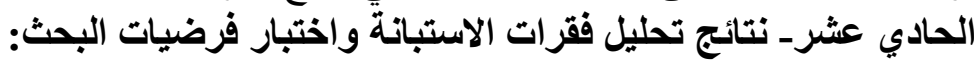

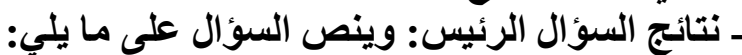

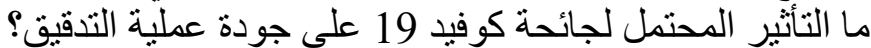

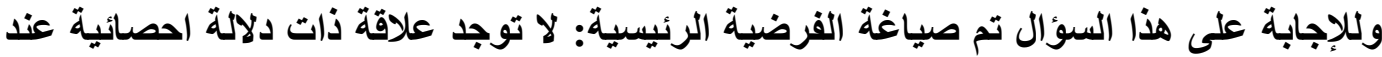

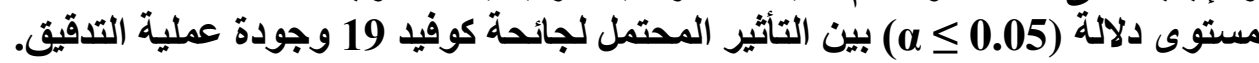

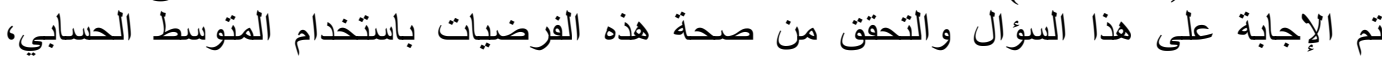
و الانحر اف المعياري، والوزن النسبي، واختبار T لمعرفة ما إذا كانت متوسط درجة الإنة الاستجابة قد

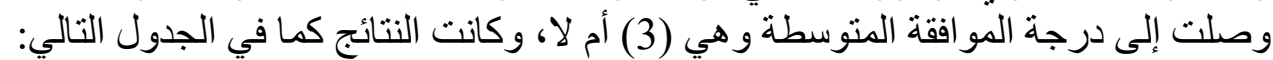

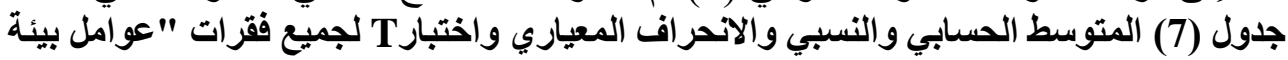

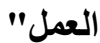

\begin{tabular}{|c|c|c|c|c|c|c|c|}
\hline الموافقة & الترتيب & 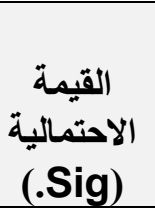 & الاختبمة & الحستوسطي & المعياري & الحستوسط & المجال \\
\hline كبيرة & 3 & .000 & 5.26 & 70.33 & 0.81 & 3.52 & الفرضية الفرعية \\
\hline كبيرة & 1 & .000 & 8.74 & 76.30 & 0.77 & 3.82 & الفرضية الفرعية الثانية \\
\hline كبيرة & 2 & .000 & 8.03 & 75.70 & 0.81 & 3.79 & الفرضية الفرعية الثالثة \\
\hline كبيرة & 4 & .000 & 4.29 & 68.48 & 0.82 & 3.42 & الفرضية الفرعية \\
\hline كبيرة & & .000 & 7.90 & 73.39 & 0.70 & 3.67 & الفرضية الرئيسية \\
\hline
\end{tabular}

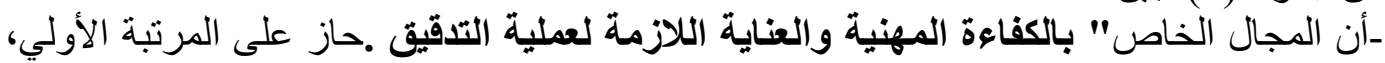

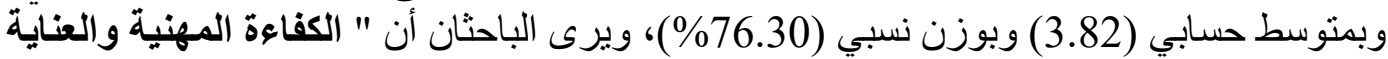

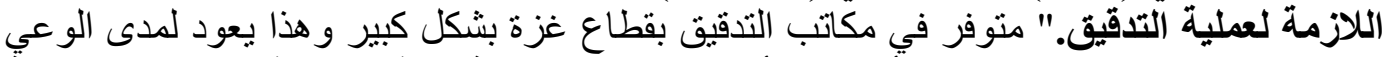
والادراك لدى مجتمع الدراسة، بأهمية التأثير المحتمل لجائحة كوفيا 19 في الكفاءة المهاتئة المهنية والعناية اللازمة لعملية التدقيق. لإن.

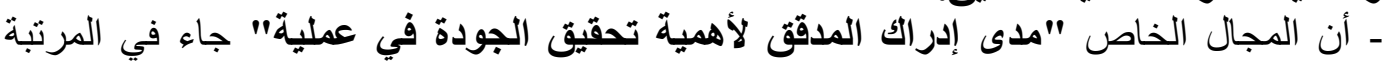

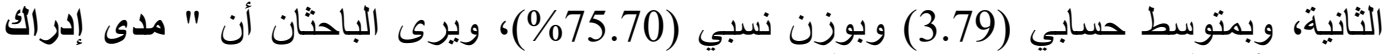

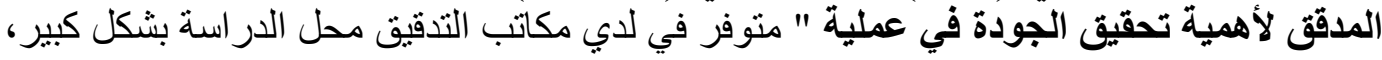


و هذه النتيجة تدل على أن لدى أفراد العينة توجهاً ايجابياً نحو هذا المحور التأثنير المحتمل لجائحة كوفيد 19 على مدى إدر الك المدقق لأهمية تحقيق الجودة في التهائ عملية.

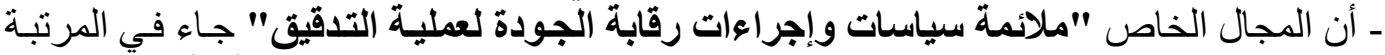

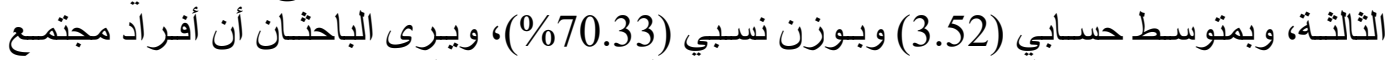

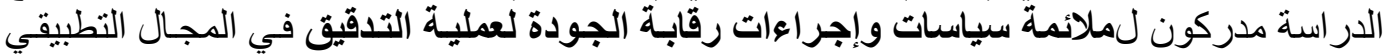

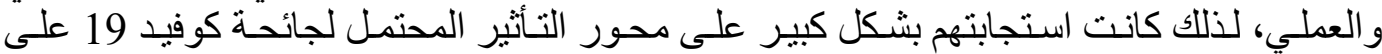

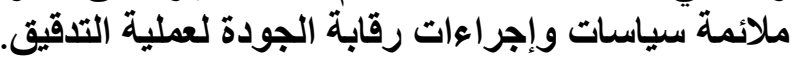

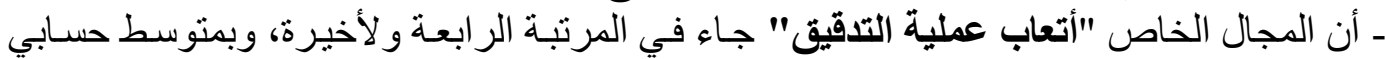

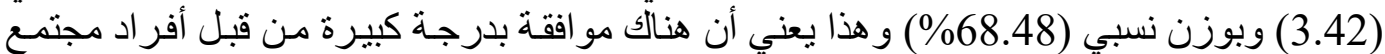
الدراسة على أتعاب عملية التدقيق.

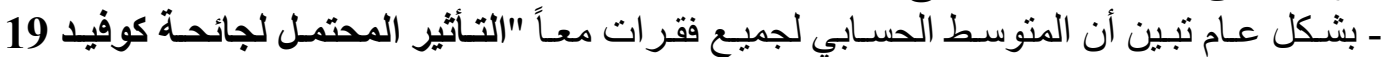

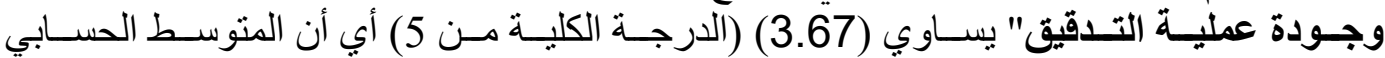

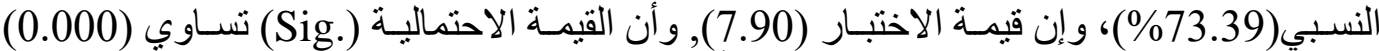

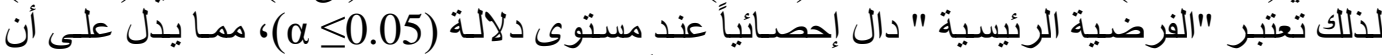

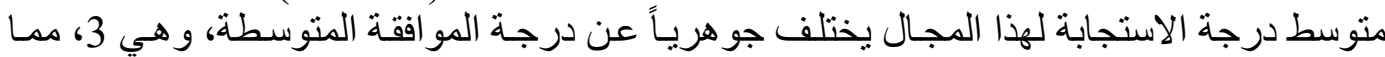

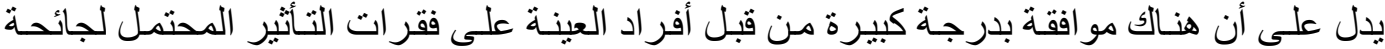

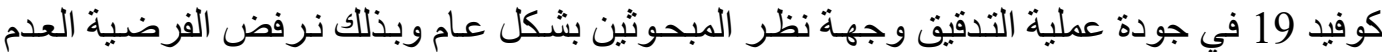

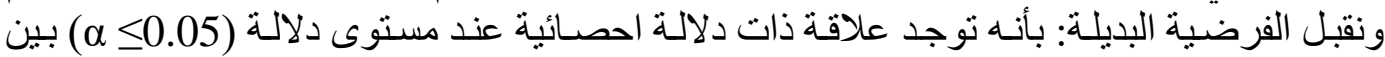
التأثير المحتمل لجائحة كوفيد 19 وجودة النزة عملية التدقيق

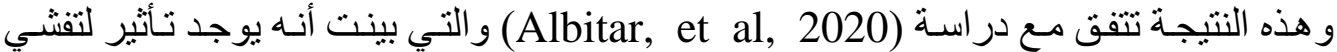

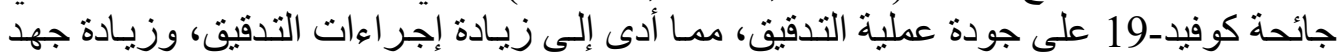

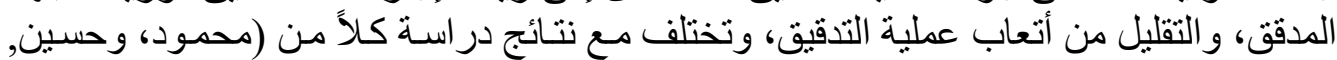

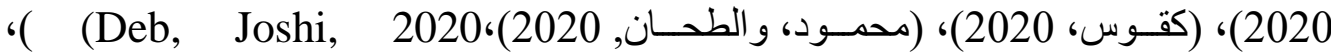

.(Chakraborty, 2020)

ـ نتائج السؤال الفرعي الأول: وينص السؤال على ما يلي:

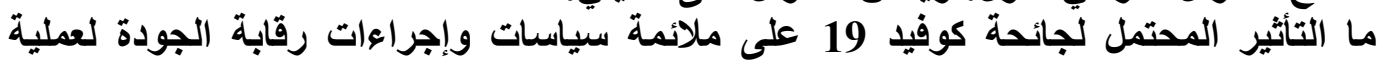
وللإجابة على هذا السؤال تم صياغة الفرضية الفرعية الأولي: لا توجد علاقة ذات دلالة إحصائية

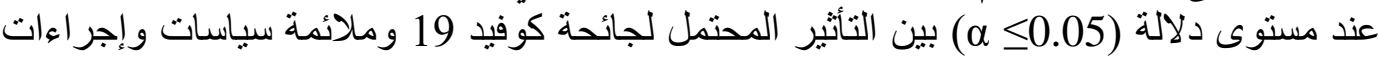
رقابة الجودة لعملية التدقيق. تم الإجابة على هذا السؤال والتحقق من صحة هذه التحأ الفرضيات باستخدام المتوسط الحسابي،

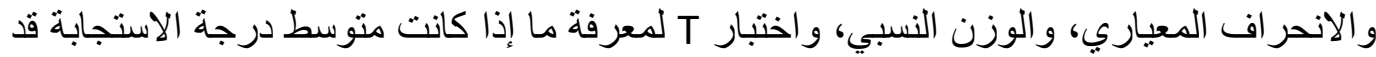

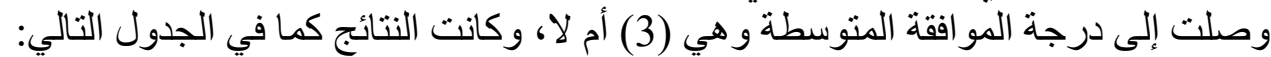

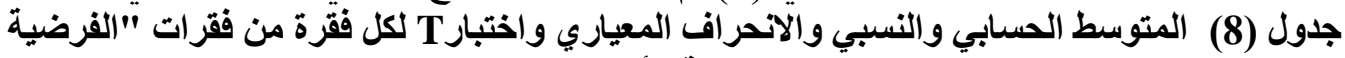

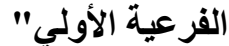

\begin{tabular}{|c|c|c|c|c|c|c|c|c|}
\hline الموافقة & الترتيب & الاحتمالية & الاختبار & الحستوبي & المعياري & الحسابي & الفقرة & P \\
\hline متوسطة & 6 & .112 & 1.61 & 64.41 & 1.13 & 3.22 & 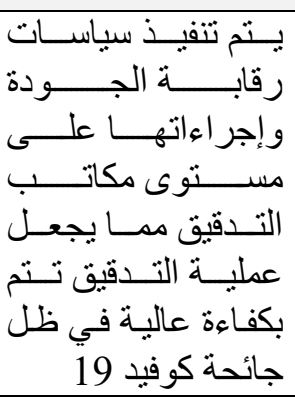 & .1 \\
\hline متوسطة & 6 & .108 & 1.63 & 64.41 & 1.12 & 3.22 & يتنفــــق أداء عـــــلـل & .2 \\
\hline
\end{tabular}




\begin{tabular}{|c|c|c|c|c|c|c|c|}
\hline & & & & & & & 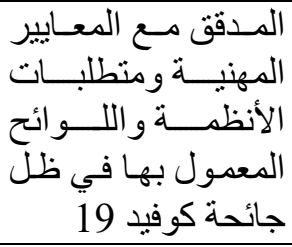 \\
\hline كبيرة & 3 & .000 & 5.21 & 72.35 & 0.98 & 3.62 & 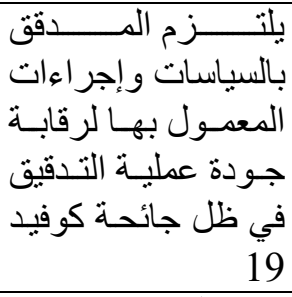 \\
\hline كبيرة & 4 & .000 & 4.22 & 71.76 & 1.15 & 3.59 & 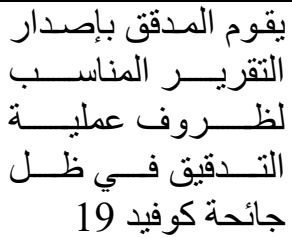 \\
\hline كبيرة & 1 & .000. & 6.34 & 74.71 & 0.96 & 3.74 & 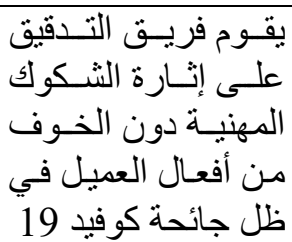 \\
\hline كبيرة & 5 & .000. & 4.08 & 70.88 & 1.10 & 3.54 & 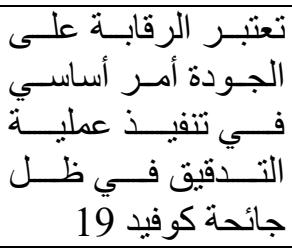 \\
\hline كبيرة & 2 & .000 & 4.75 & 73.82 & 1.20 & 3.69 & 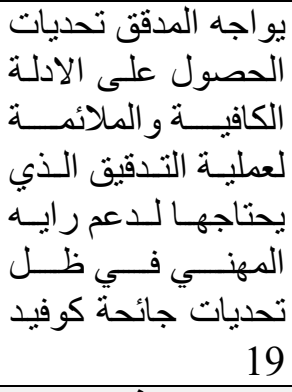 \\
\hline كبيرة & & .000. & 5.26 & 70.33 & 0.81 & 3.52 & 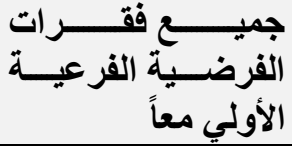 \\
\hline
\end{tabular}

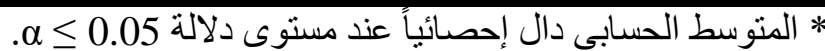

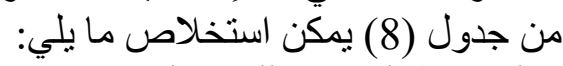

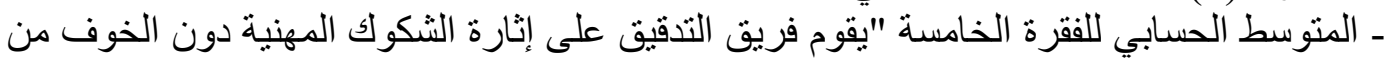

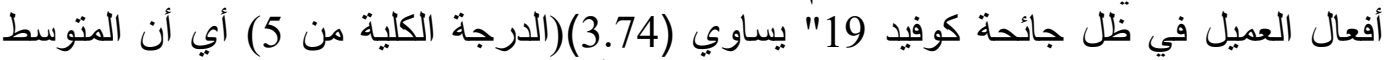

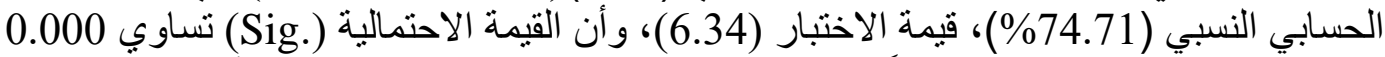

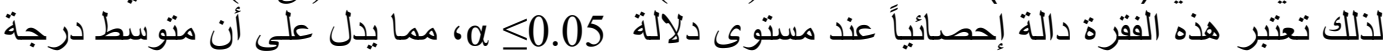

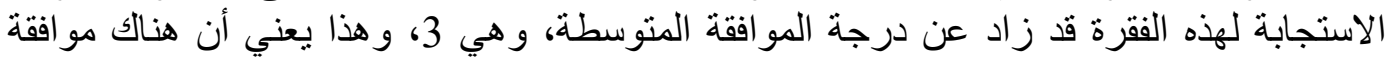
بدرجة كبيرة من قبل أفراد العينة على هذه الفقرة، وبذلك جاء ترتيبها في المرتبة الأولى في هذا هذا

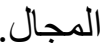
ــ المتوسط الحسابي للفقرة الأولي "يتم تتفيذ سياسات رقابة الجودة وإجر اءاتها على مستوى مكاتب

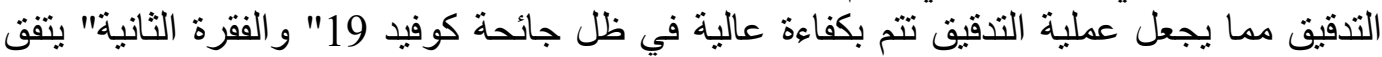

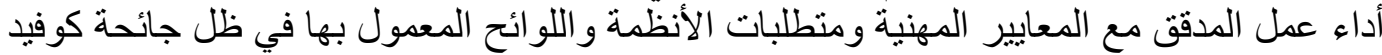
19 "يساوي (3.22)(الدرجة الكلية من 5) أي أن المتوسط الحسابي النسبي (64.41\%)، قيمة 


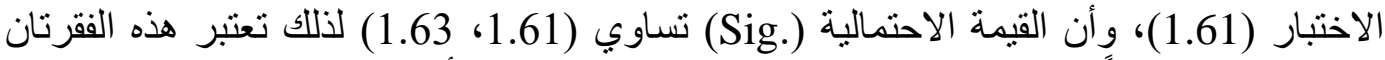

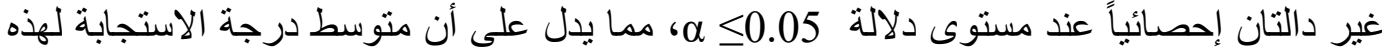

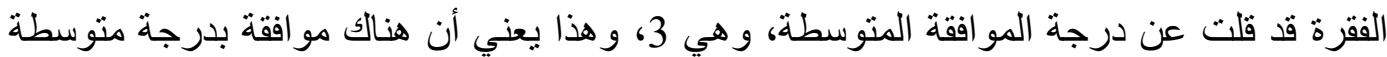

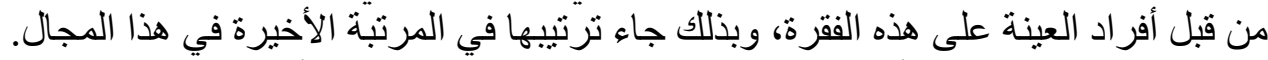

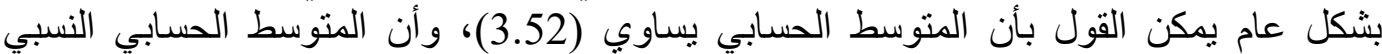

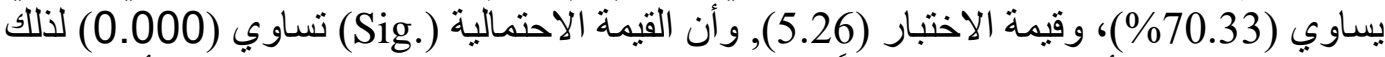

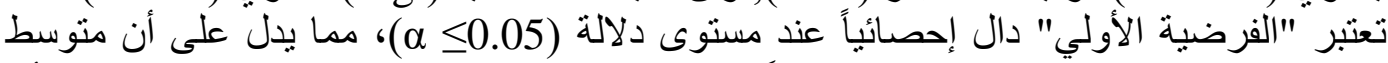

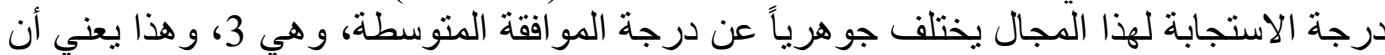

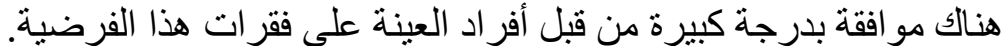
وبذلك نرفض الفرضية العدم ونقبل الفرضية البديلة: بأنه توجد علاقية ذاتية ذات دلالة إحصائية عند

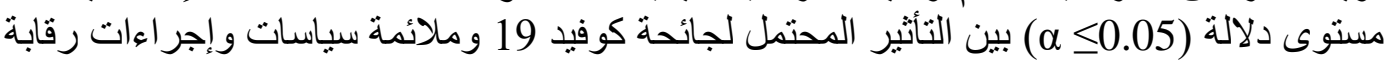

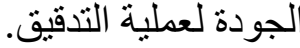

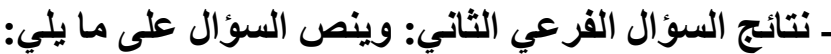

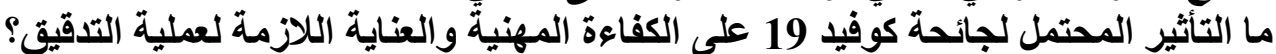

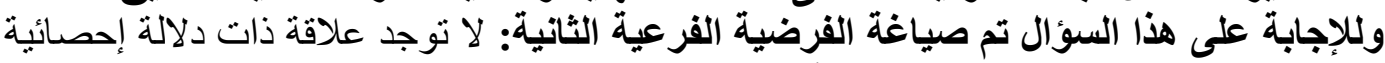

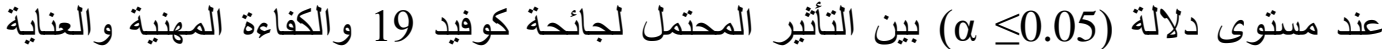

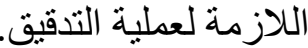

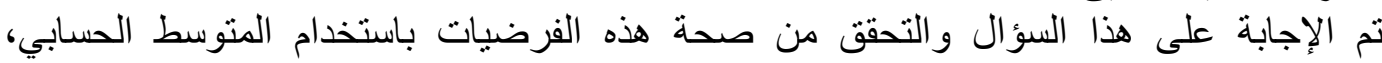
و الانحر اف المعياري، والوزن النسبي، واختبار T لمعرفة ما إذا كانت متوسط درجة الإنة الاستجابة قد

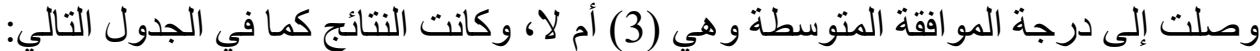

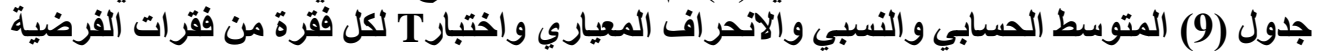

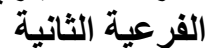

\begin{tabular}{|c|c|c|c|c|c|c|c|c|}
\hline الموافقة & الترتيب & $\begin{array}{c}\text { الاحتمالية } \\
\text { (Sig) }\end{array}$ & الاختبار & الحستوسي & المعياري & الحسابي & الفقرة & b \\
\hline كبيرة & 5 & .000 & 6.86 & 75.88 & 0.96 & 3.79 & 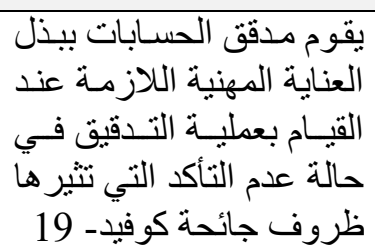 & .1 \\
\hline كبيرة & 7 & .004 & 2.99 & 69.41 & 1.30 & 3.47 & 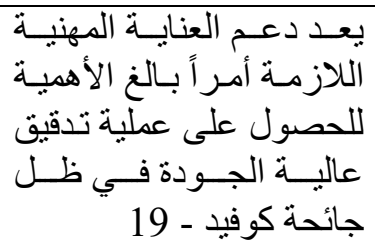 & .2 \\
\hline كبيرة & 6 & .000 & 4.62 & 72.94 & 1.16 & 3.65 & 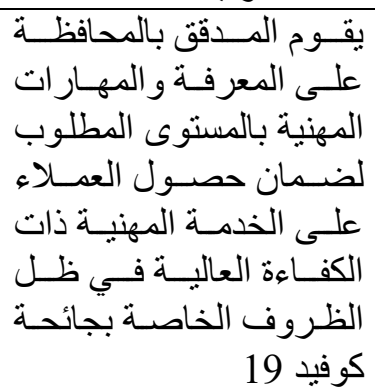 & .3 \\
\hline كبيرة & 2 & .000 & 9.19 & 78.82 & 0.84 & 3.94 & 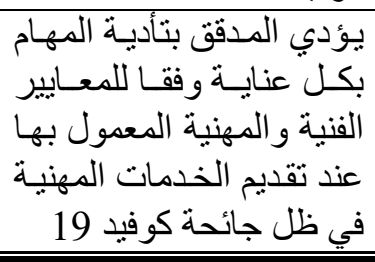 & .4 \\
\hline
\end{tabular}




\begin{tabular}{|c|c|c|c|c|c|c|c|c|}
\hline كبيرة & 1 & .000 & 8.01 & 79.71 & 1.01 & 3.99 & 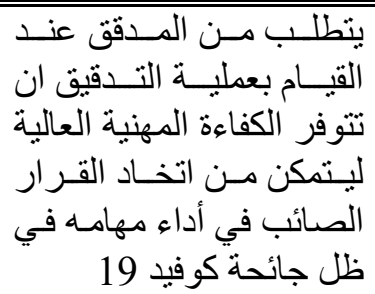 & .5 \\
\hline كبيرة & 2 & .000 & 7.96 & 78.82 & 0.98 & 3.94 & 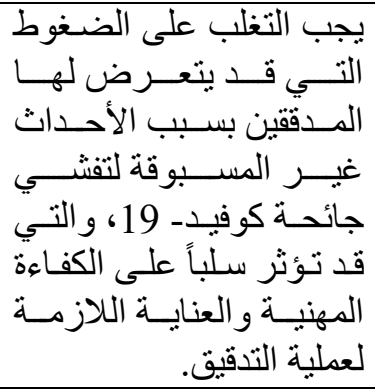 & .6 \\
\hline كبيرة & 4 & .000 & 8.62 & 78.53 & 0.89 & 3.93 & 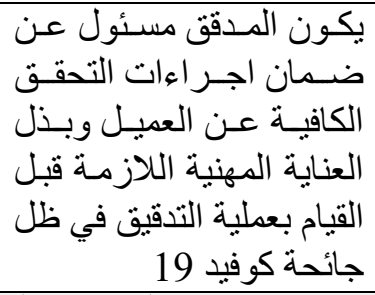 & .7 \\
\hline كبيرة & & .000 & 8.74 & 76.30 & 0.77 & 3.82 & 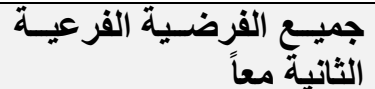 & \\
\hline
\end{tabular}

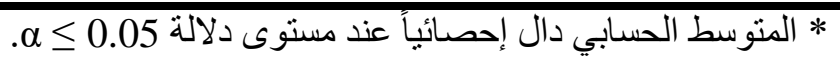

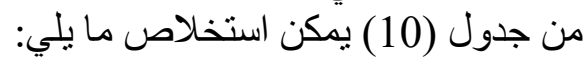

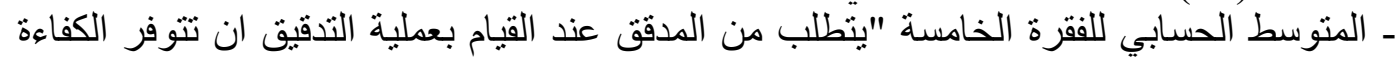

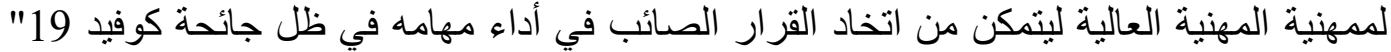

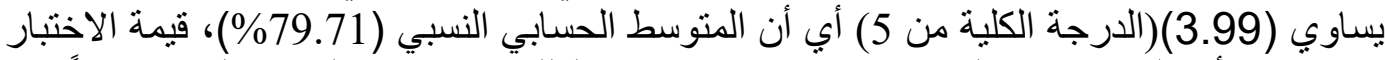

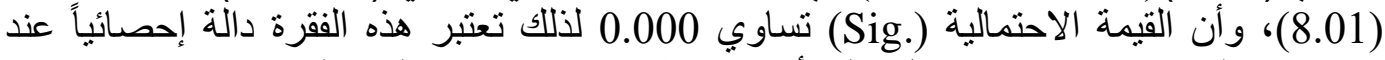

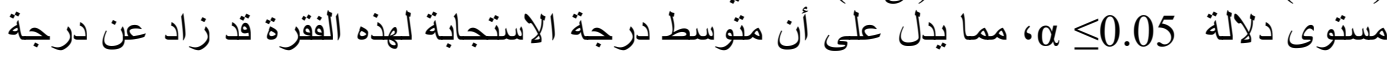

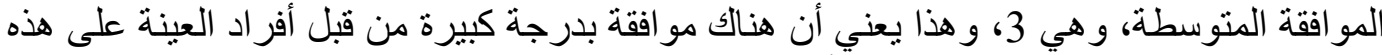

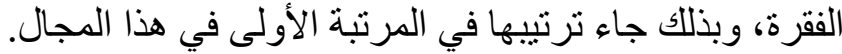

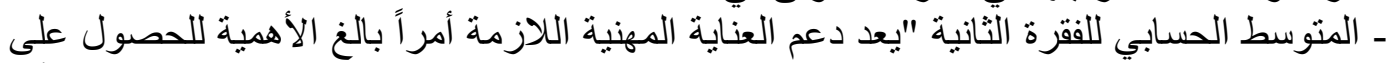

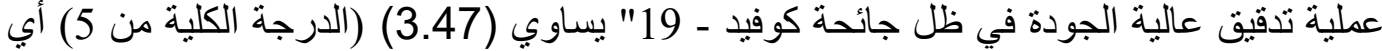

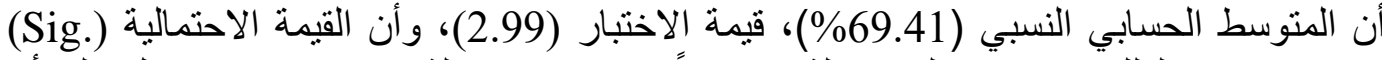

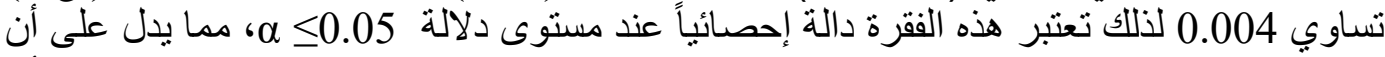

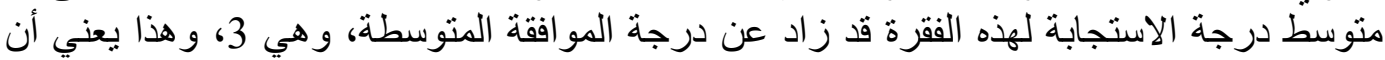

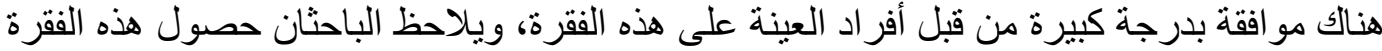

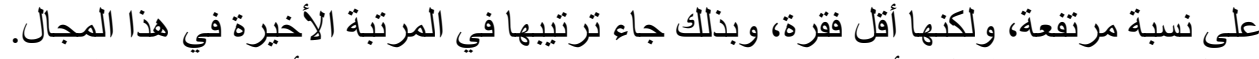

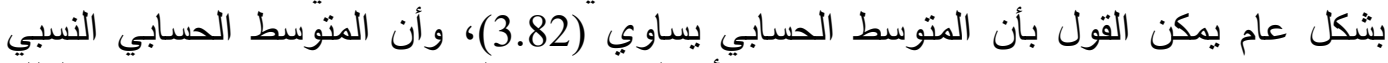

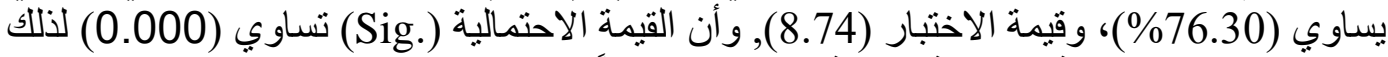

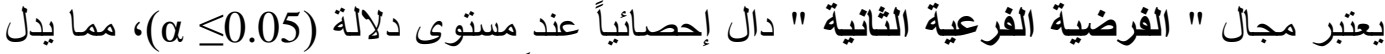

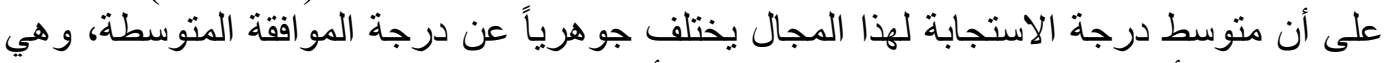

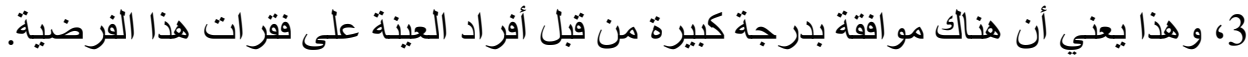

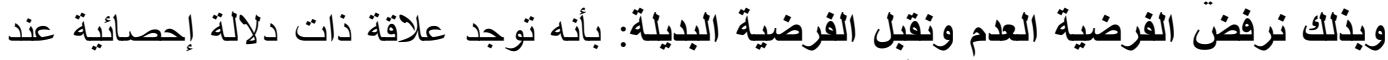

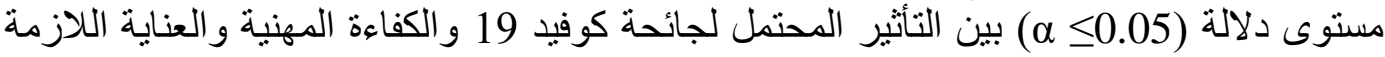

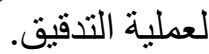
ـ نتائج السؤال الفرعي الثالث: وينص السؤال على ما يلي: ما التأثير المحتمل لجائحة كوفيد 19 على مدى إدراك الكئ المدقق لأهمية تحقيق الجودة في عملية 
وللإجابة على هذا السؤال تم صياغة الفرضية الفرعية الثالثة: لا توجد علاقة ذات دلالة إحصائية

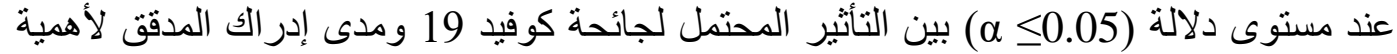
تحقيق الجودة في عملية التدقيق

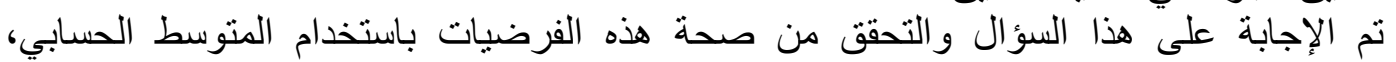

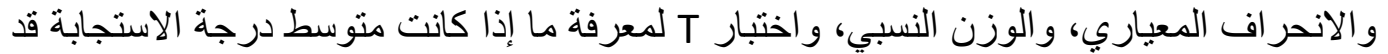

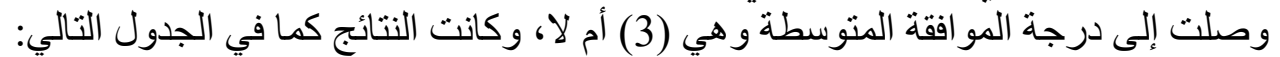

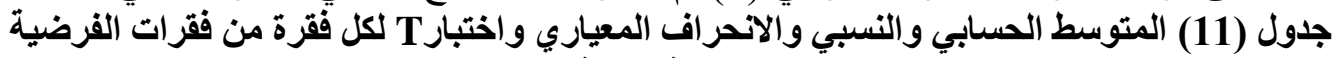
الفرعية الثالثة الثياري

\begin{tabular}{|c|c|c|c|c|c|c|c|c|}
\hline الموافقة & الترتيب & الاحتمالية & الاختبرا & الحستوبي النسبي & المعياري & المستوسط & الفقرة & م \\
\hline كبيرة & 6 & .000 & 3.85 & 70 & 1.07 & 3.50 & 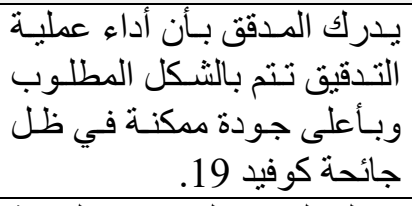 & .1 \\
\hline كبيرة & 5 & .000 & 4.80 & 71.76 & 1.01 & 3.59 & 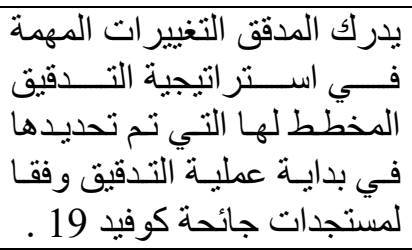 & .2 \\
\hline كبيرة & 4 & .000 & 5.81 & 75.88 & 1.13 & 3.79 & 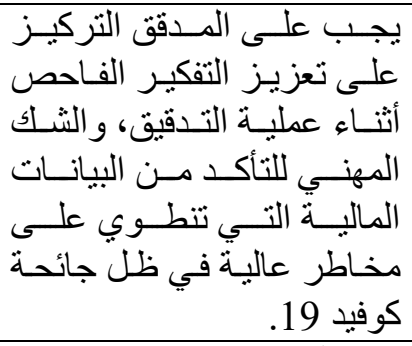 & .3 \\
\hline كبيرة & 3 & .000 & 7.06 & 77.06 & 1.00 & 3.85 & 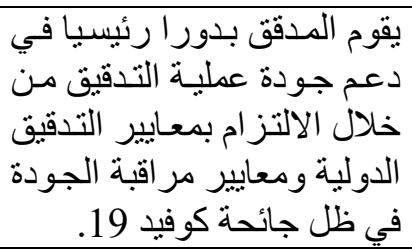 & 4 \\
\hline كبيرة & 2 & .000 & 7.77 & 79.70 & 1.04 & 3.99 & 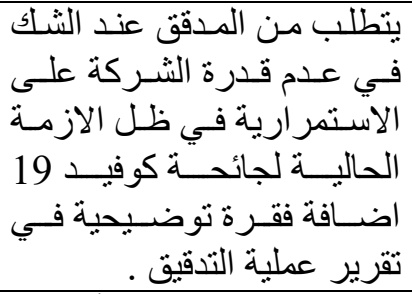 & .5 \\
\hline كبيرة & 1 & .000 & 8.38 & 79.71 & 0.97 & 3.99 & 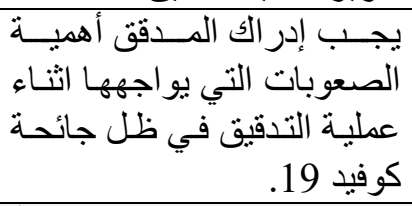 & 6 \\
\hline كبيرة & & .000 & 8.03 & 75.70 & 0.81 & 3.79 & 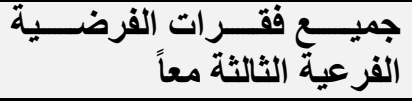 & \\
\hline
\end{tabular}

من جدول (11) يمكن استخلاص إصنائ مند ما يلي:

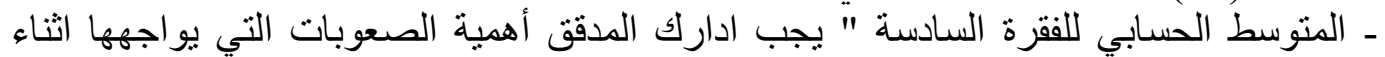

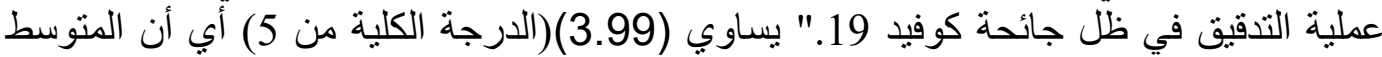

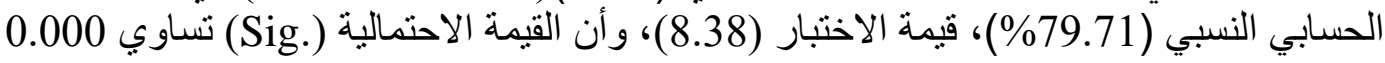




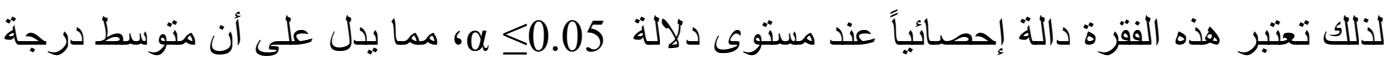

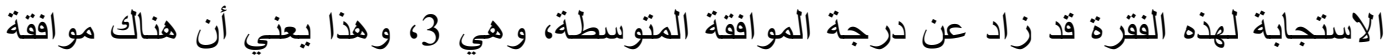
بدرجة كبيرة من قبل أفراد العينة على هذه الفقرة، وبذلك جاء ترتيبها في المرتبة الأولى في هذا

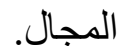
ـ المتوسط الحسابي للفقرة الأولي " يدرك المدقق بأن أداء عملية التدقيق تتم بالثكل المطلوب

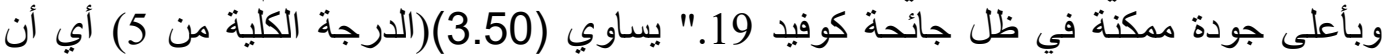

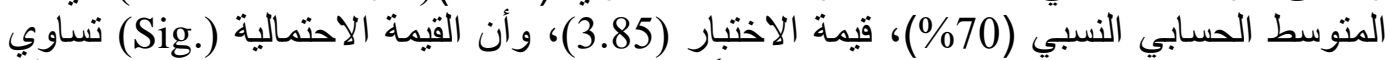

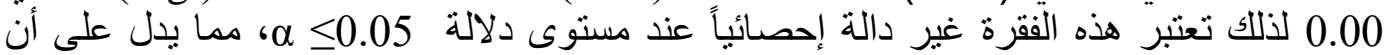

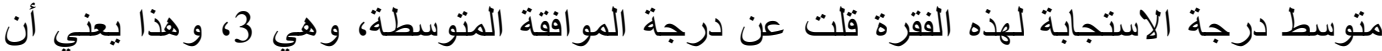

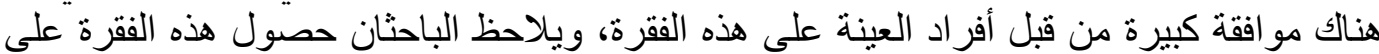

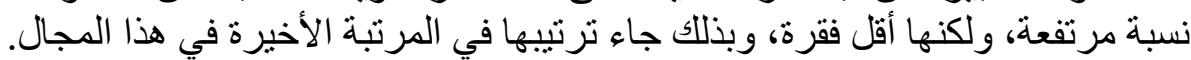

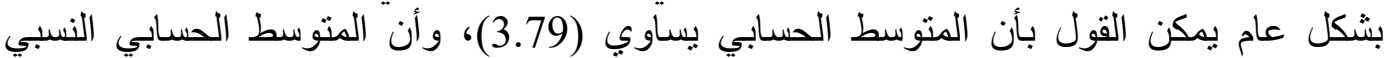
يساوي (75.70\%)، وقيمة الاختبار (8.03), وأن القيمة الاحتمالية (3ig) (Sig) تساوي (0.000) لذلك الك

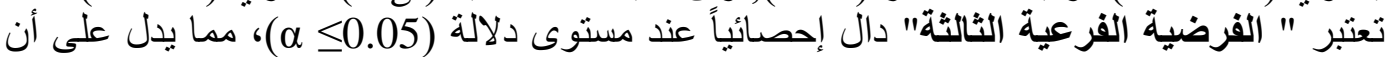

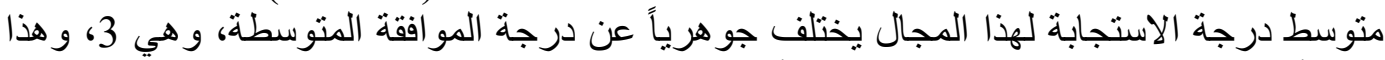

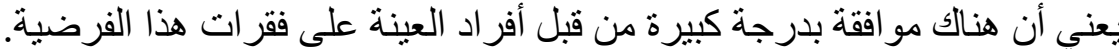

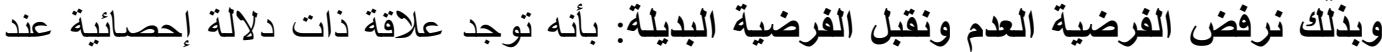

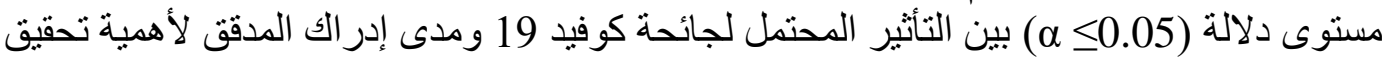

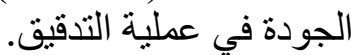

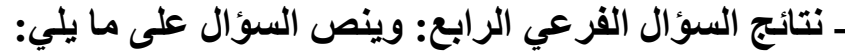

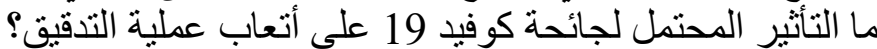

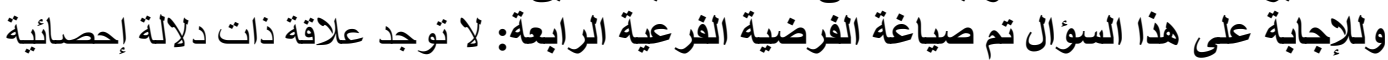

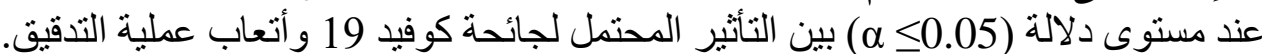
تم الإجابة على هذا السؤال والتحقق من صحة هذه الفرضيات باستخدام المتوسط الحسابي،

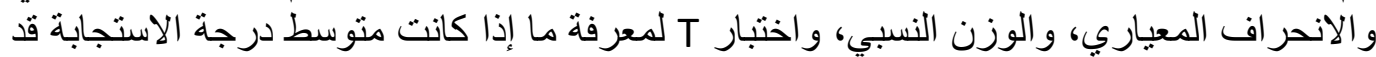

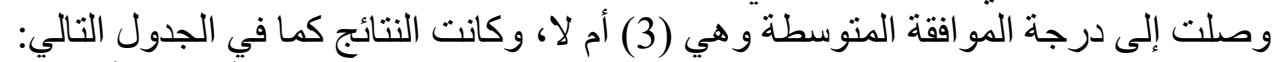

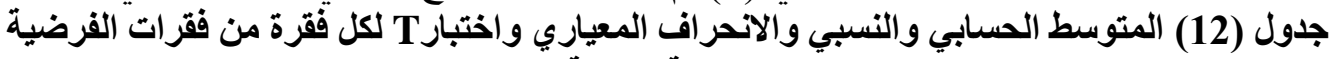

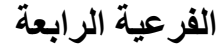

\begin{tabular}{|c|c|c|c|c|c|c|c|c|}
\hline الموافقة & الترتيب & $\begin{array}{c}\text { الاحتمالية } \\
\text { (Sig) }\end{array}$ & قاختبمة & النسبابي & المعياري & الحستوسي & الفقرة & p \\
\hline كبيرة & 1 & .000 & 4.59 & 73.53 & 1.21 & 3.68 & 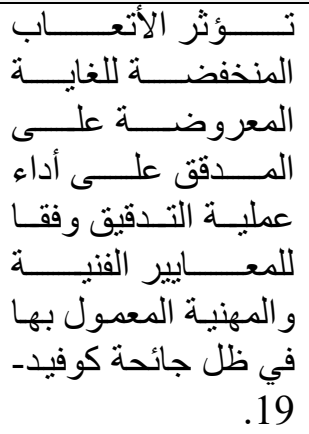 & 1 \\
\hline منوسطة & 2 & .000 & 4.02 & 70.59 & 1.09 & 3.53 & 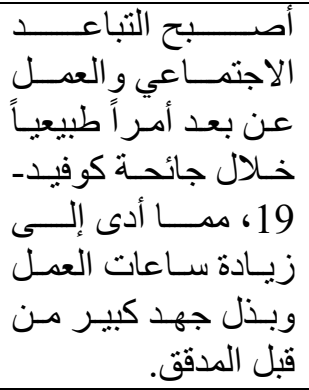 & 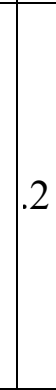 \\
\hline
\end{tabular}




\begin{tabular}{|c|c|c|c|c|c|c|c|}
\hline كبيرة & 6 & .049. & 2.01 & 65.37 & 1.10 & 3.27 & 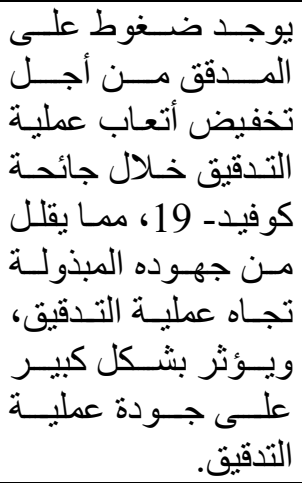 \\
\hline كبيرة & 7 & . 150 & 1.46 & 64.12 & 1.17 & 3.21 & 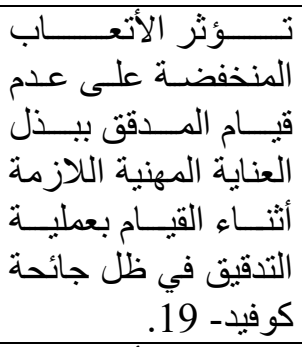 \\
\hline كبيرة & 4 & .000. & 3.76 & 69.12 & 1.00 & 3.46 & 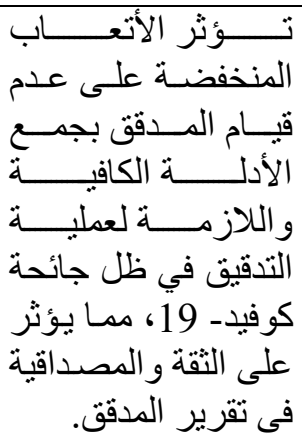 \\
\hline كبيرة & 5 & .045. & 2.05 & 65.88 & 1.19 & 3.29 & 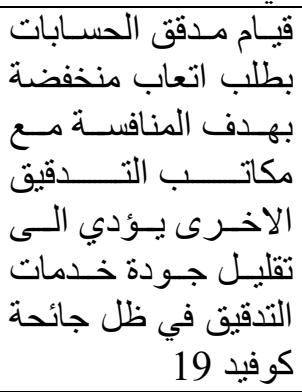 \\
\hline كبيرة & 3 & .000 & 3.86 & 70.29 & 1.10 & 3.51 & 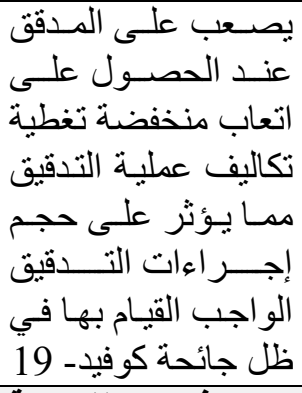 \\
\hline كبيرة & & .000. & 4.29 & 68.48 & 0.82 & 3.42 & جميع فقرات الفرابعة معاً \\
\hline
\end{tabular}

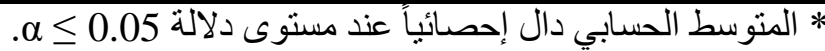

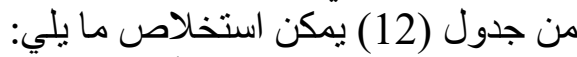

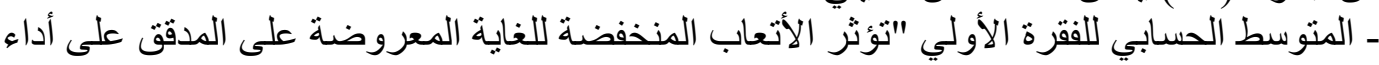

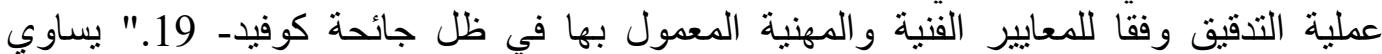

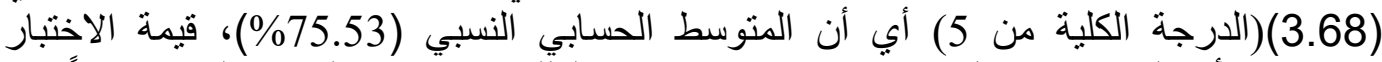

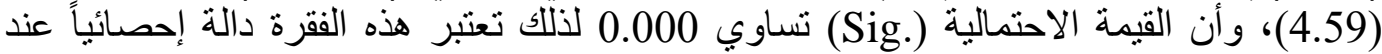

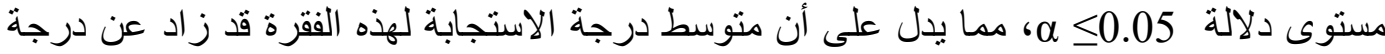


المو افقة المتوسطة، و هي 3، وهذا يعني أن هناك مو افقة بدرجة كبيرة من قبل أفر اد العينة على هذه

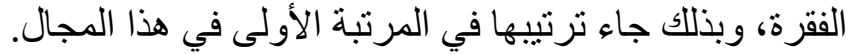

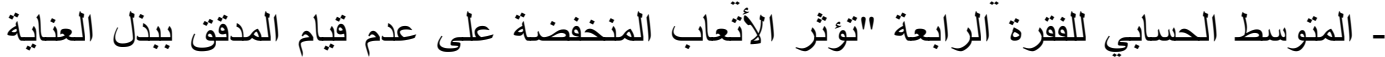

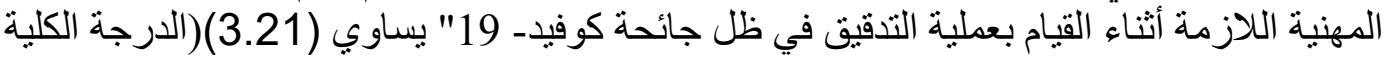
من 5) أب أن المتوسط الحسابي النسبي (154.12\%)، قيمة الإختبار (1.46)، وأن القيمة الاحتمالية (Sig.) تساوي 0.150 لذلك تعتبر هذه الفقرة غير دالة إحصائياً عند مستوى دلالة

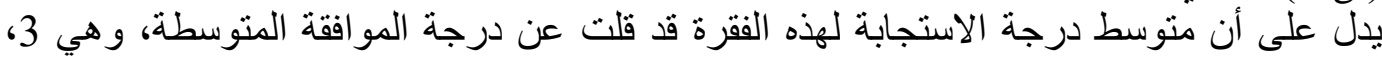
و هذا يعني أن هناك مو افقة بدرجة قريبة من المتوسطة من قبل أفر اد العينة على هذه الفقرة، وبذلك الكية

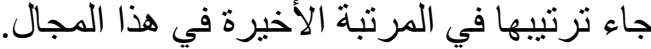

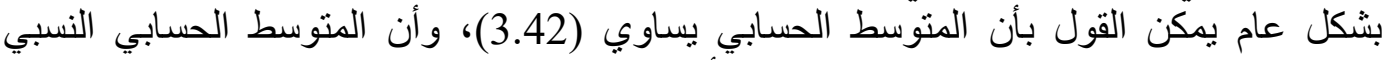

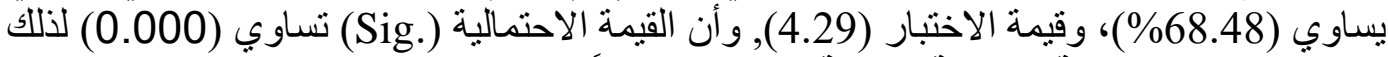

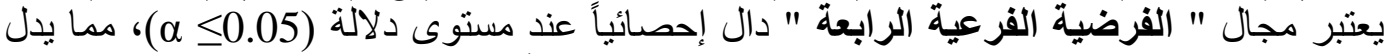

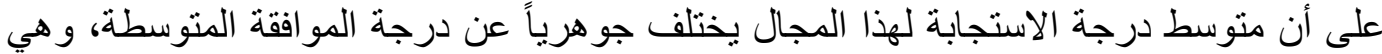

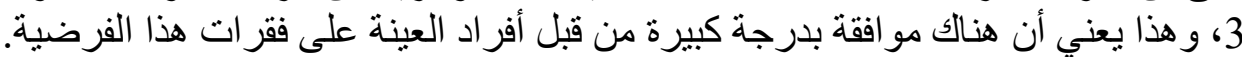

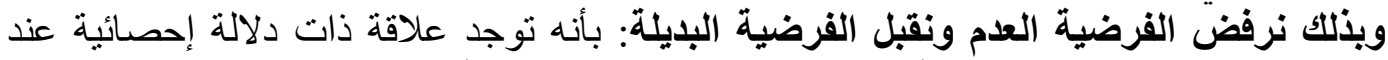

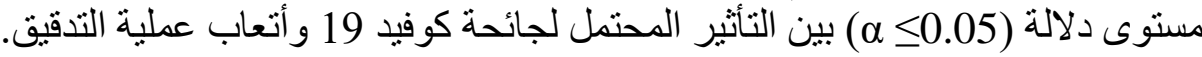

ـنتائج السؤال الرئيس الثاني: والذي ينص على: هل يوجد فروق بين متوسطات استجابات

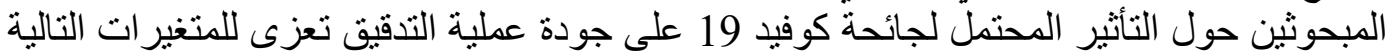

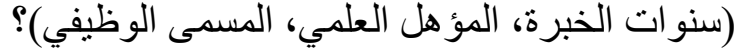

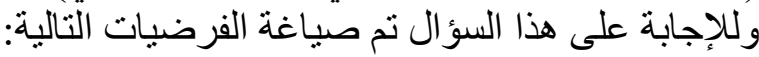

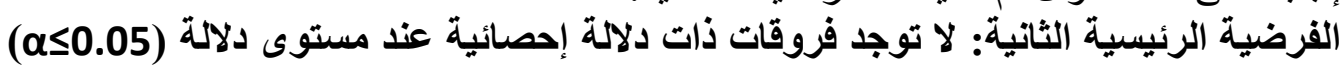

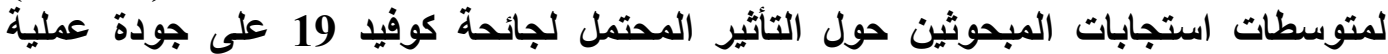

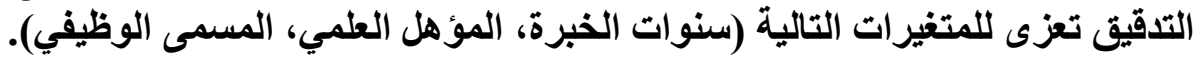

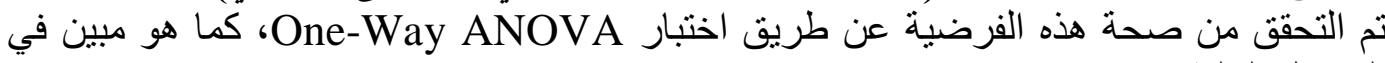

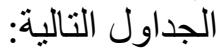

جدول رقم (13) اختبار الفروق

\begin{tabular}{|c|c|c|c|c|c|c|}
\hline \multicolumn{2}{|c|}{ المسمى الوظيفي } & \multicolumn{2}{|c|}{ المؤهل العلمي } & \multicolumn{2}{|c|}{ سنوات الخبرة } & المتغير \\
\hline \multicolumn{2}{|c|}{ اسم الأختبار "التباين } & \multicolumn{2}{|c|}{ اسم الأختبار "التباين } & \multicolumn{2}{|c|}{ الأحم الاختبار "التباين } & الاختبار \\
\hline القيمة الاحتمالية & الاختبمة & القيمة الاحتمـلية "Sig." & الاختبار & $\begin{array}{l}\text { الاحتمالية } \\
\text { "Sig." }\end{array}$ & قاختبمة & 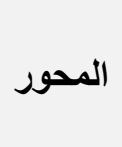 \\
\hline 0.817 & 0.203 & 0.989 & 0.011 & 0.281 & 1.294 & \\
\hline 0.690 & 0.372 & 0.872 & 0.137 & 0.105 & 2.33 & \\
\hline 0.826 & 0.192 & 0.456 & 0.794 & 0.421 & 0.877 & الفرايّة \\
\hline 0.483 & 0.735 & 0.427 & 0.861 & 0.418 & 0.884 & الفرضية \\
\hline 0.814 & 0.206 & 0.823 & 0.196 & 0.255 & 1.394 & الفرضية \\
\hline
\end{tabular}


وقد تبين من الجدول السبابق أن:

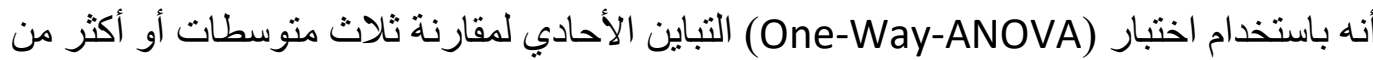

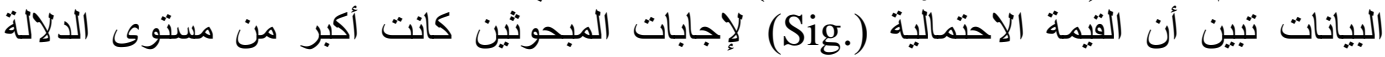

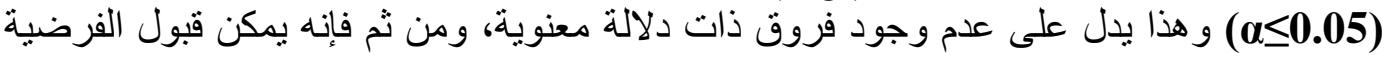

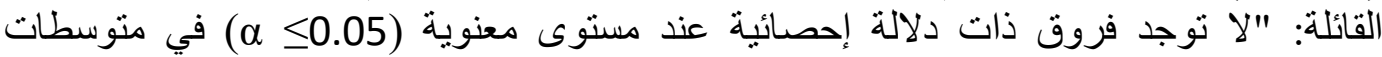

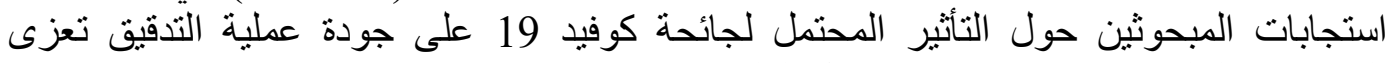
اللمتغيرات التالية (سنو ات الخبرة، المؤهل العلمي، المسمى الوظيفي)".

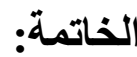

تعد هذه الدراسة محاولة لبيان التأثير المحتمل لجائحة كوفيد 19 على جودة عملية التدقيق، وتقتضي الإني

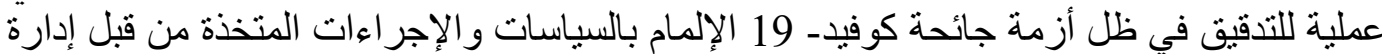

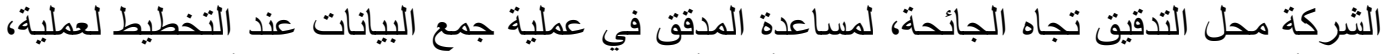

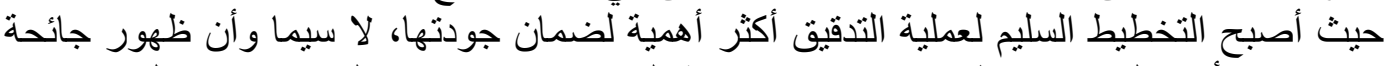

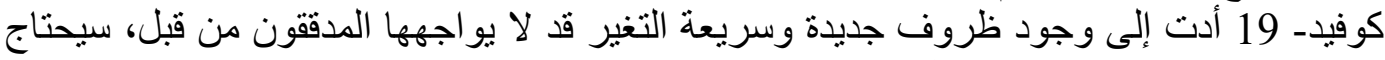

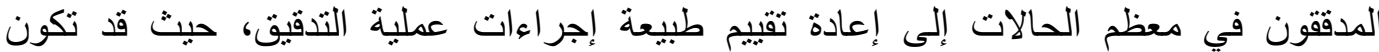

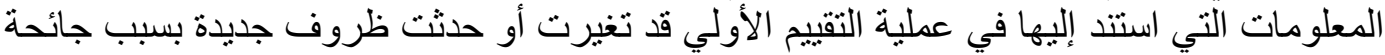

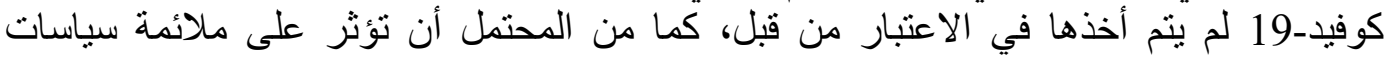

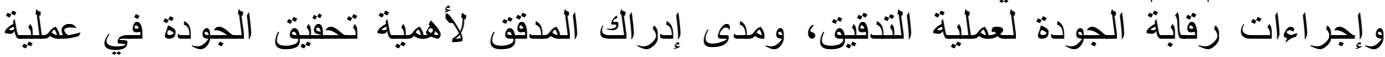
التدقيق، وكذلك على الكفاءة المنية و العناية اللازمة لعملية التدقيق، مما يؤثر بشكل و اضحح على لئى

أتعاب عملية التدقيق. وبناءً على نتائج التحليل الإحصائي للبيانات و استقصاء آراء مجتمع الدراسة نستتنج أنه يوجد تأثير

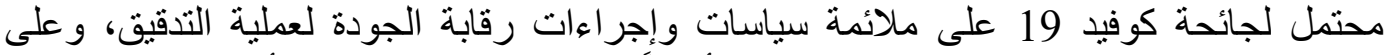

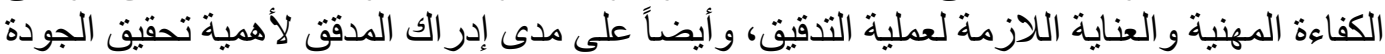
في عملية التدقيق، و على أتعاب عملية التدقيق.

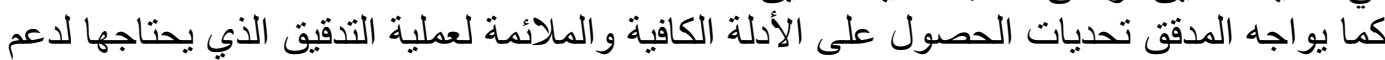

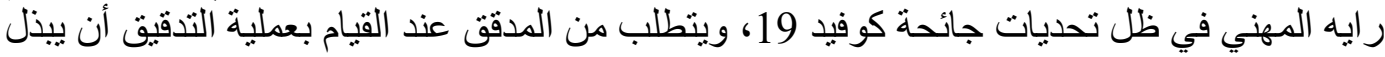

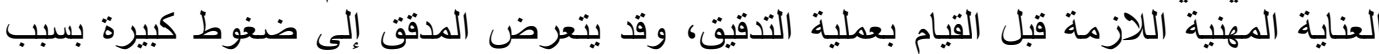

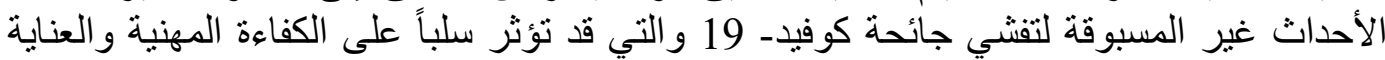

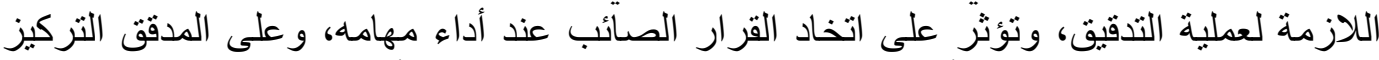
على تعزيز التفكير الفاحص أثناء عملية التدقيق، و الثنك المهني للتأكد من البيانات المالية التي التي تنطوي على مخاطر عالية في ظل الجائحة.

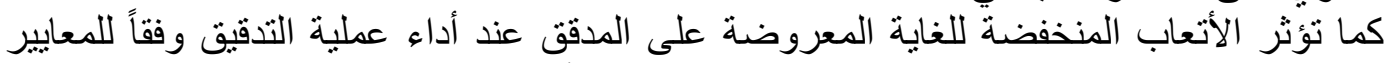

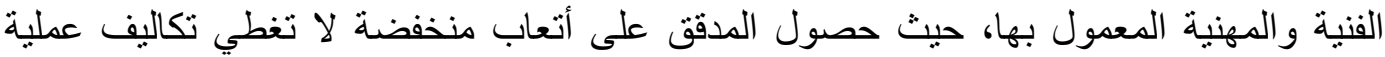
التدقيق قد تؤثر على حجم إجراءات التدقيق الواجب القيام بها في ظل الظروف غير العادية لجائحة

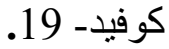

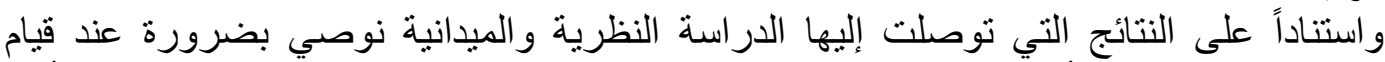

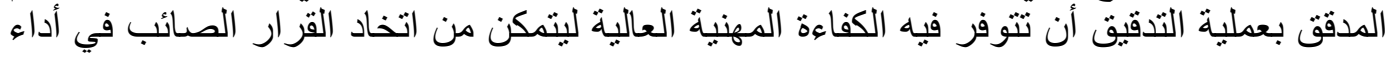

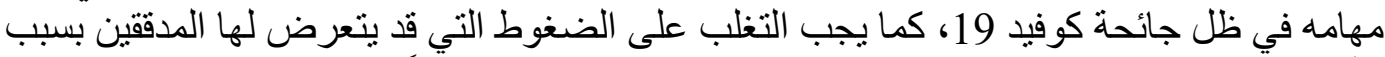

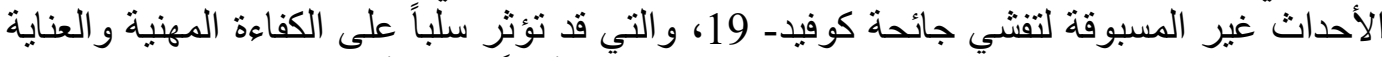

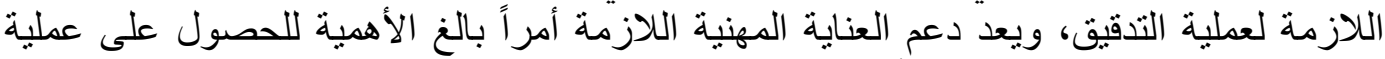
تدقيق عالية الجودة في ظل عدم التأكد المصاحبة للجائحة.

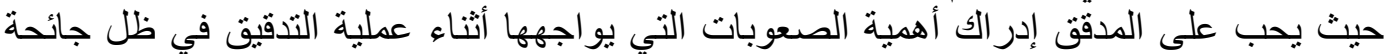

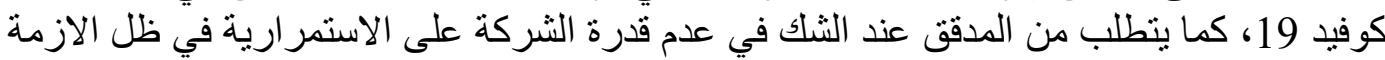

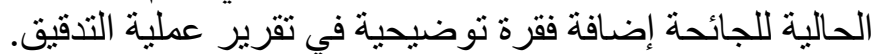

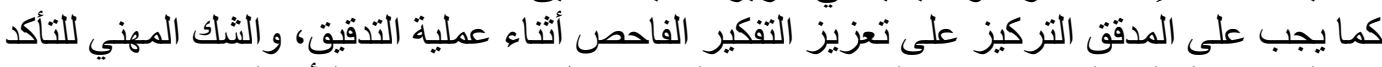
من البيانات المالية التي تنطوي على مخاطر عالية في ظل ظروف على التراء التأكد لجائحة كوفيد 19، 
كما يجب على المدقق عدم السماح بتأثير الضغوط من أجل تخفيض أتعاب على عملية التدقيق في ظل الجائحة والتي تقلل من جهوده المبذولة تجاه عملية التدقيق، وتؤثر بشكل كبير على جودة عملية

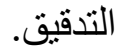

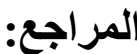

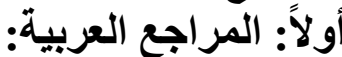

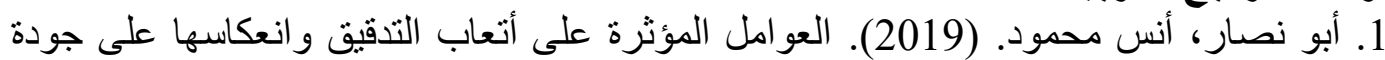

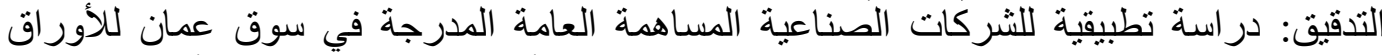

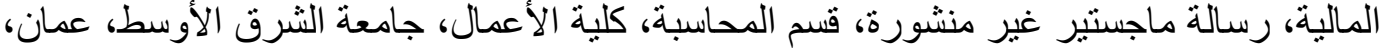

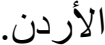
2. التميمي، جمانة حنظل. (2012). العوامل المؤثرة في جودة العملية التدقيقية، مجلة الاقتصاد

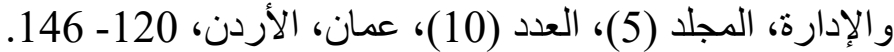

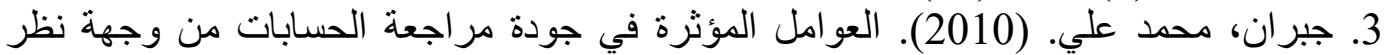

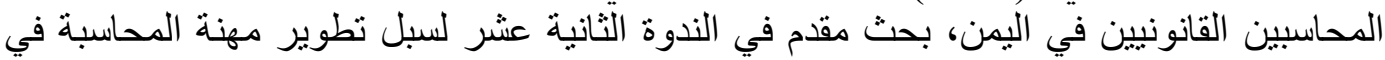

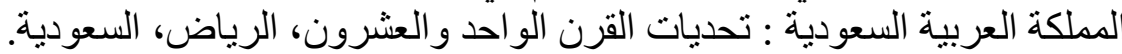

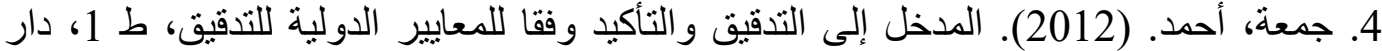
صفاء للنشر و التوزيع، عمان، الأردن.

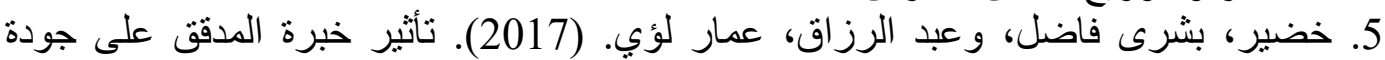

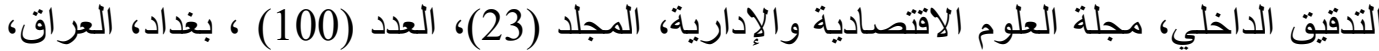
$.815-601$ 6. السيد، هاتش. (2015) (2020). مهنة المحاسبة في ظل أزمة كورونا، مجلة الراية، يمكن استرجاعها

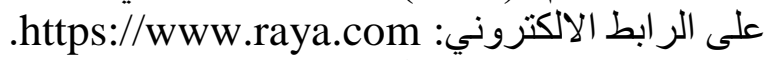

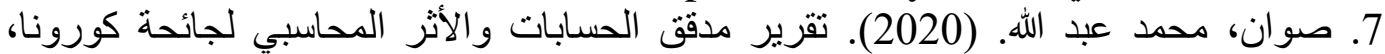

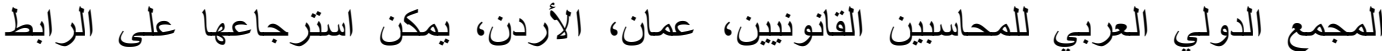

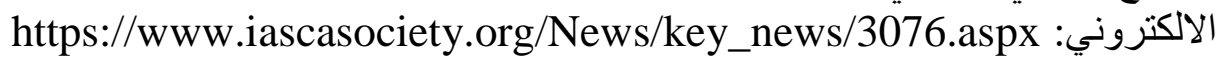

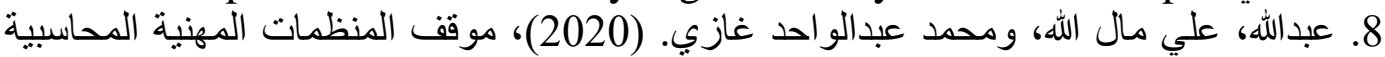

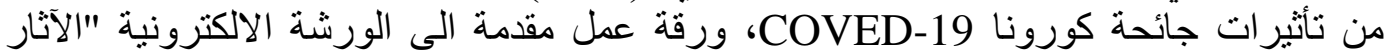

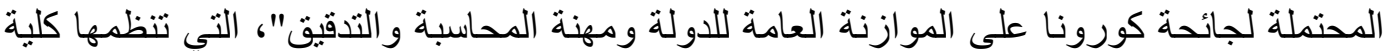

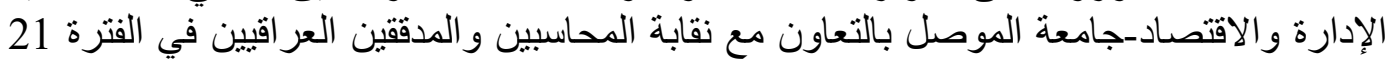

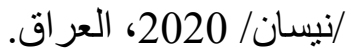
9. الكببجي، مجدي و ائل. (2020). التنظير المحاسبي في ظل وباء كورونا تشخيص و اقعي، يمكن

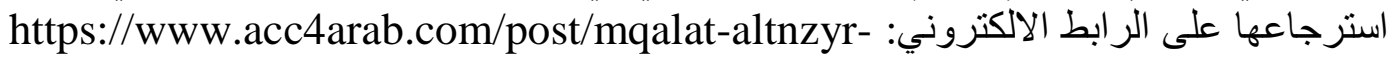
almhasby-fy-zl-wbaa-alkwrwna-tshkhys-waqay

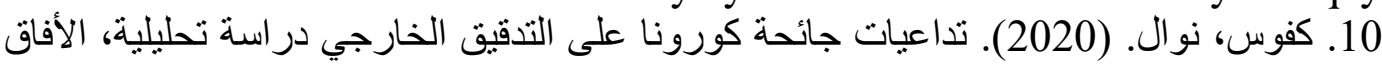

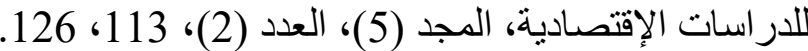

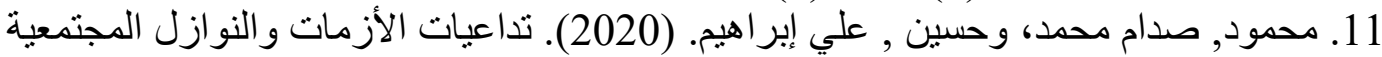

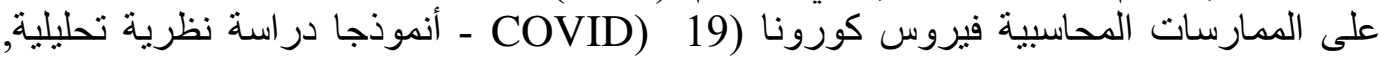
جامعة تكريت, كلية الإدارة والاقتصاد, مجلة تكريت للعلوم الإدارية والاقتصادية, المجلد (16)

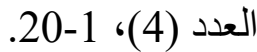

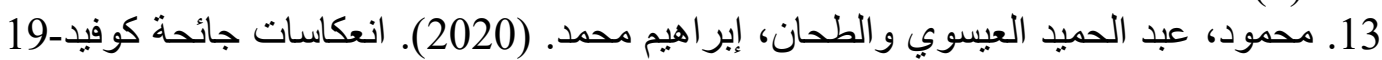

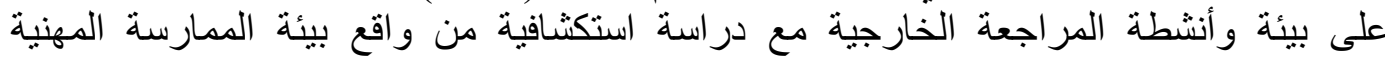
المصرية, جامعة الإسكندرية، كلية التجارة، قسم المحاسبة والمر اجعة, مجلة الإسكندرية للبحوث

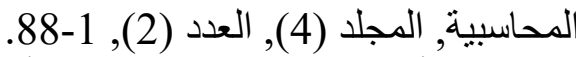

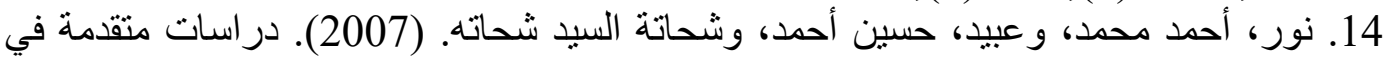
مر اجعة الحسابات، الدار الجامعية، الإسكندرية، جمهورية مصر العدية العربية.

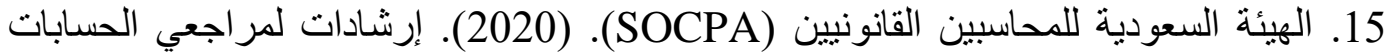

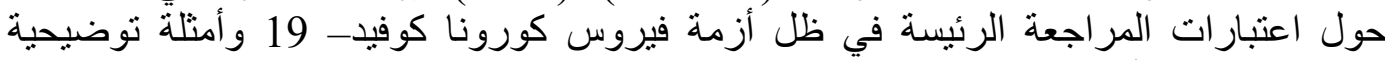

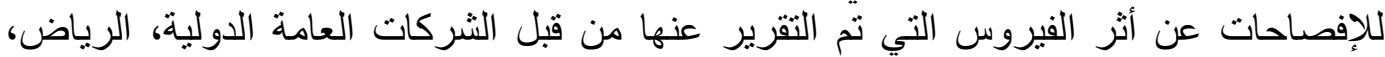

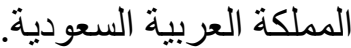




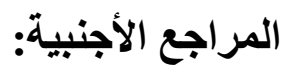

1. ACCA. (2020). Covid-19 Global Survey: Inside business- impacts and responses, Professional insight report. https://www.accaglobal.com/gb/en/professional-insights/global-economics/Covid19_A-Global-Survey.html.

2. Albitar, Khaldoon, Gerged, Ali Meftah, Kikhia, Hassan and Hussainey, Khaled. (2020). Auditing in times of social distancing: The effect of COVID-19 on auditing quality, International Journal of Accounting and Information Management, https://www.researchgate.net/publication/343876817.

3. Deb, Rajat and Chakraborty, Sourav. (2020). COVID-19-Potential Financial Auditing Challenges, https://www.researchgate.net/publication/342513901.

4. Albitar, Khaldoon, Gerged, Ali Meftah, Kikhia, Hassan and Hussainey, Khaled. (2020). Auditing in times of social distancing: The effect of COVID-19 on auditing quality, International Journal of Accounting and Information Management, See discussions, stats, and author profiles for this publication at: https://www.researchgate.net/publication/343876817, 1-14.

5. Center For Audit Quality (CAQ). (2020). COVID-19 Resource: Key Auditor and Audit Committee Considerations, https://www.thecaq.org/caq-covid-19resource/.

6. International Federation of Accountants (IFAC). (2020). Practical Audit Quality Considerations for Auditing in the Pandemic Environment, Webinar Series: Planning the Audit in the Pandemic Environment Summary of Key Takeaways.

7. Joshi, P L. (2020). Editorial: Covid-19 Pandemic and Financial Reporting Issues and Challenges, International Journal of Auditing and Accounting Studies, Vol. (1), No.2, 1-9.

8. KPMG. (2020). COVID-19: Potential impact on financial reporting, Accessed on the 27th of April 2020 at https://home.kpmg/xx/en/home/insights/2020/03/covid-19-financial-reportingresource-centre.html.

9. Salehi, Mahdi. Kangarlouei, and Saeid Jabarzadeh. (2010). An Investigation of the Effect of Audit Quality on Accrual Reliability of Listed Companies on Tehran Stock Exchange, Review of International Comparative Management, Vol. 11, Vol. 5, 940-960.

10. The Institute of Charted Accountants of Pakistan, (2020). The Impact of Covid- 19 on Audit- A Guidance for Auditors, http://www.icap,net.pk/guidance. 11. The International Auditing and Assurance Standards Board (IAASB). (2020). Audit Quality an Iaasb Perspective. 